\title{
PERFORMANCE OF NO VIBRATION/NO ADMIXTURE MASONRY GROUT CONTAINING HIGH REPLACEMENT OF PORTLAND CEMENT \\ WITH FLY ASH AND GROUND GRANULATED \\ BLAST FURNACE SLAG
}

\author{
A Thesis \\ presented to \\ the Faculty of California Polytechnic State University, \\ San Luis Obispo
}

\author{
In Partial Fulfillment \\ of the Requirements for the Degree
}

Master of Science in Architecture with a Specialization in Architectural Engineering

by

Eric Bateman

February 2014 
(C) 2014

Eric Bateman

ALL RIGHTS RESERVED 


\section{COMMITTEE MEMBERSHIP}

TITLE:

AUTHOR:

DATE SUBMITTED:

COMMITTEE CHAIR:
Performance of No Vibration/No Admixture Masonry

Grout Containing High Replacement of Portland Cement with Fly Ash and Ground Granulated Blast Furnace Slag

Eric Bateman

February 2014

James Mwangi, Ph.D., S.E.

Professor of Architectural Engineering

COMMITTEE MEMBER: $\quad$ Craig Baltimore, Ph.D., S.E.

Professor of Architectural Engineering 


\author{
ABSTRACT \\ Performance of No Vibration/No Admixture Masonry Grout Containing \\ High Replacement of Portland Cement with Fly Ash and Ground \\ Granulated Blast Furnace Slag \\ Eric Bateman
}

When hollow concrete masonry is used for construction in high seismic regions, structural designs typically require fully grouted walls. The grouting process is laborintensive, time-consuming and has a high energy demand due to requirements of consolidation in each and subsequent grout lifts. Self-consolidating grout with admixtures has been successfully used without segregation in walls of up to $12.67 \mathrm{ft}$. in height. Investigation of self-consolidating grout mixes without admixtures has potential for sustainability improvement.

This thesis reports on the compression strength and consolidation observations of self-consolidating characteristics of no vibration/no admixture grout made by substituting various proportions of Portland cement with Type F fly ash and/or ground granulated blast furnace slag (GGBFS). The percentages of Portland cement replacement evaluated were $0 \%, 50 \%, 60 \%$, and $70 \%$ for Type $\mathrm{F}$ fly ash. The percentages of Portland cement replacement evaluated were $0 \%, 60 \%, 70 \%$ and $80 \%$ for Type F fly ash and GGBFS.

Grout compressive strengths were evaluated from individually filled grout specimens constructed in concrete masonry hollow core units, dry cured, and tested after 7, 14, 28, 42, 56, and 130 days. Also, hollow concrete masonry walls were built $12.67 \mathrm{ft}$. tall and grouted. The relative performance was assessed by comparing to conventional grouted masonry and evaluating consolidation characteristics around mortar fins and reinforcement; compressive strength tests after 130 days of curing, and rebar pull-out tests were taken from various wall heights.

All experimental grouts had acceptable consolidation characteristics but fly ash replacement grouts did not meet the compressive strength requirements.

Keywords: Self-Consolidating Grout, Fly Ash Replacement, No Vibration/Admixture 


\section{ACKNOWLEDGMENTS}

The following organizations have supported this study and without their monetary, material, and labor contributions, this test program would not have been possible: Concrete Masonry Association of California and Nevada (CMACN), Masonry

Institute of America (MIA), Pacific Coast Building Products, Basalite Concrete Products, Bricklayers \& Allied Craftworkers Local Union No. 4, and Coastal Demo Inc.

I would also like to thank Ray Ward, the College of Architecture and Design Laboratory Technician, for his assistance in the Laboratories. 


\section{TABLE OF CONTENTS}

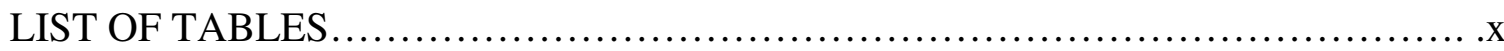

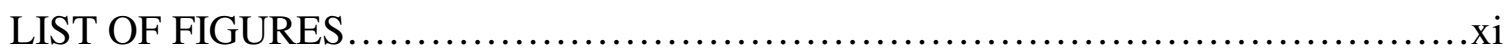

\section{CHAPTER}

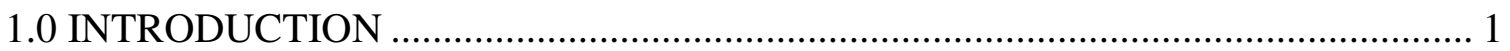

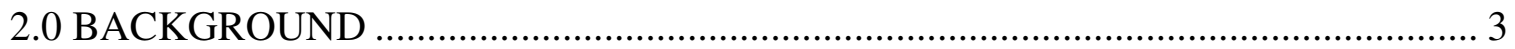

2.1 Environmental Benefits................................................................................... 3

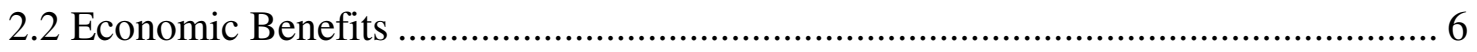

2.3 Requirements of Self-Consolidating Grout......................................................... 7

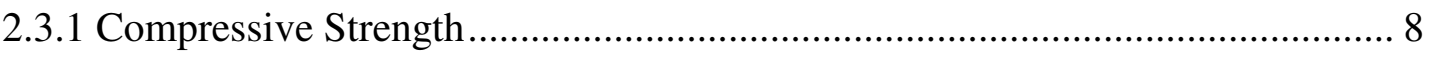

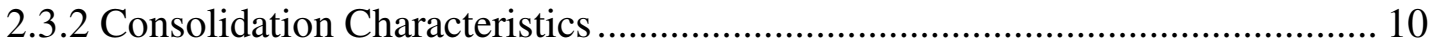

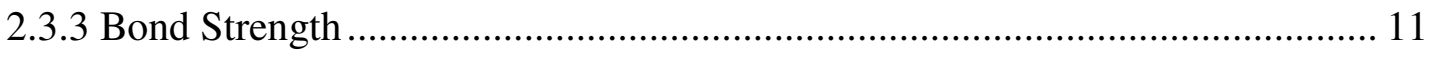

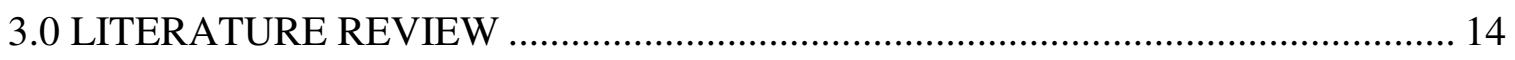

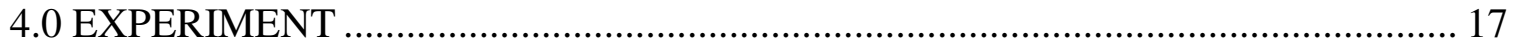

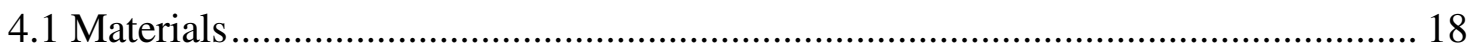

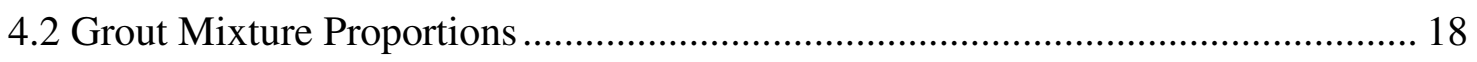

4.3 The Compression Experiment ........................................................................ 21

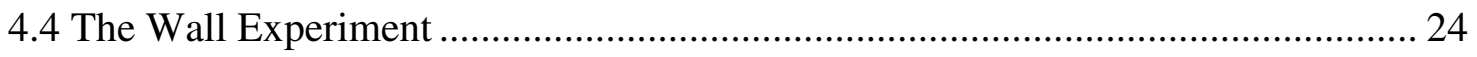

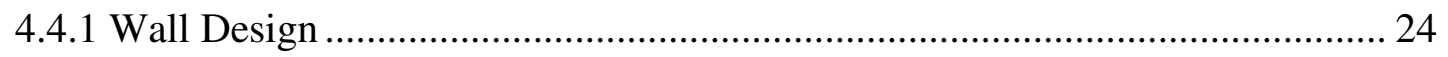

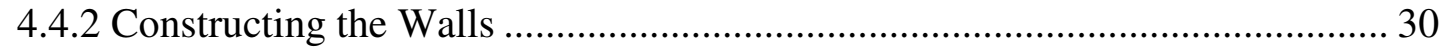

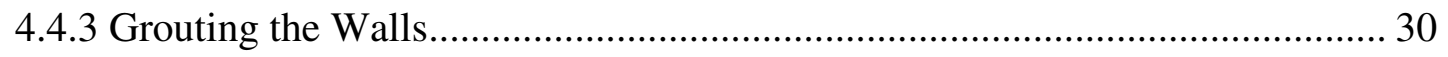

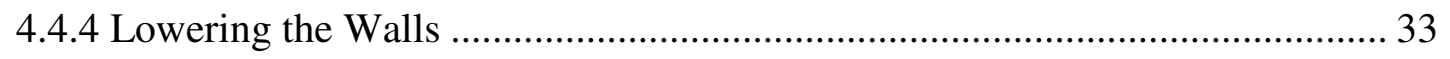

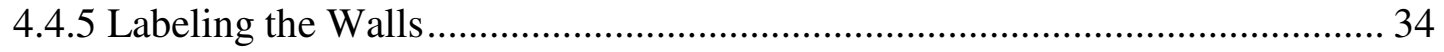

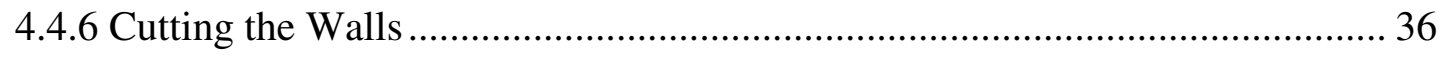

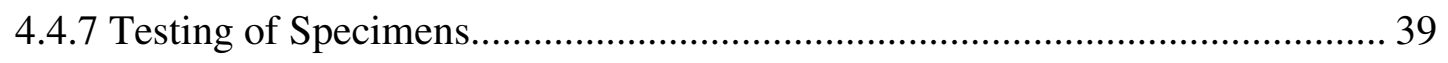




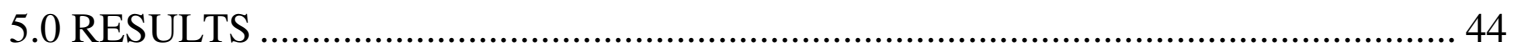

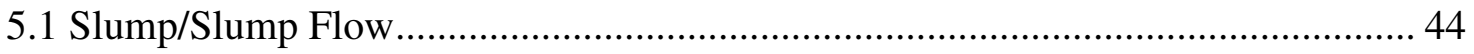

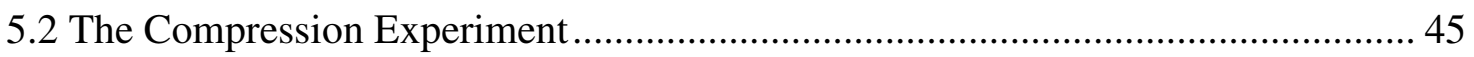

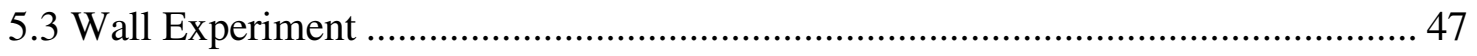

5.3.1 Wall Compression Tests ............................................................................... 47

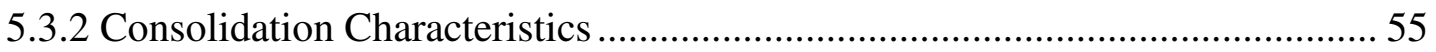

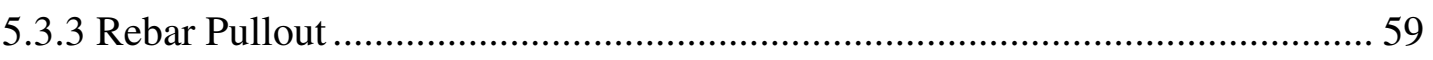

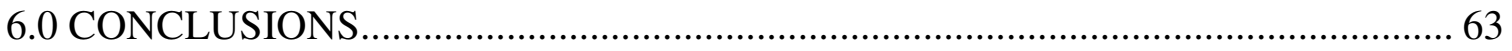

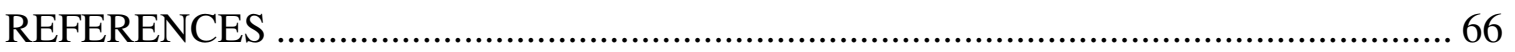

APPENDICES

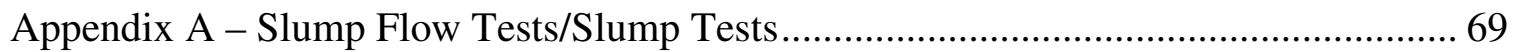

A.1 Slump Test Investigation of Conventional Grout.................................................... 69

A.2 Slump Flow Test Investigation of Experimental Grouts......................................... 70

A.3 Slump Test for The Compression Experiment ...................................................... 76

A.4 Slump Flow Tests for The Compression Experiment …………………………..... 77

A.5 Slump Test for The Wall Experiment .................................................................. 78

A.6 Slump Flow Tests for The Wall Experiment........................................................ 79

Appendix B - Grout Compressive Strengths from Compression Experiment ................. 80

B.1 Compression Test Specimens: 7 Days of Curing ………………........................ 80

B. 2 Compression Test Specimens: 14 Days of Curing ................................................. 81

B.3 Compression Test Specimens: 28 Days of Curing .............................................. 82

B.4 Compression Test Specimens: 42 Days of Curing .............................................. 83

B.5 Compression Test Specimens: 56 Days of Curing ................................................. 84

B.6 Compression Test Specimens: 130 Days of Curing ………………………......... 85

Appendix C - Grout Compressive Strengths from The Wall Experiment ....................... 86

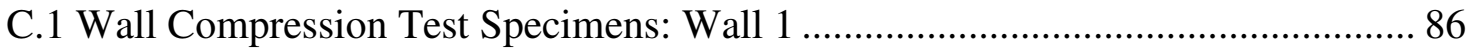

C.2 Wall Compression Test Specimens: Wall 2 ………………………………........ 89

C.3 Wall Compression Test Specimens: Wall 3 ………………………................... 92 
Appendix D - Normalized and Averaged Compression Data from the

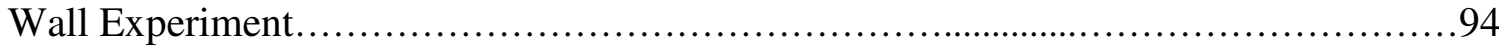

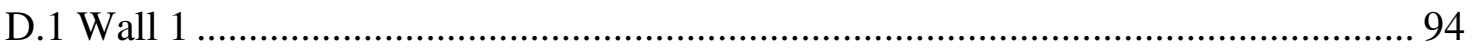

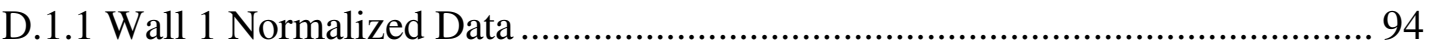

D.1.2 Wall Compression Test Specimens: Identical Data Sets Combined and

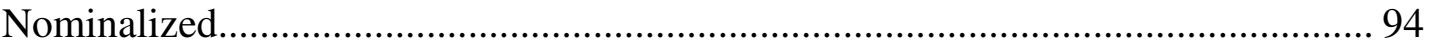

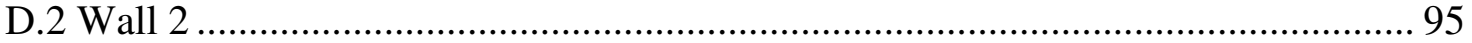

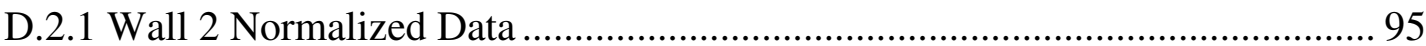

D.2.2 Wall Compression Test Specimens: Identical Data Sets Combined and

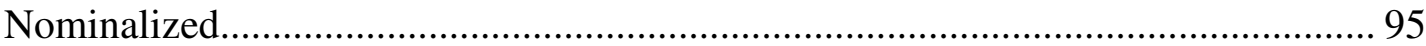

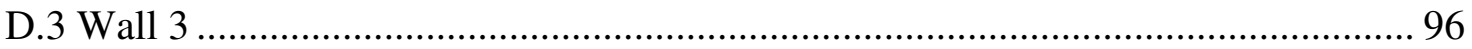

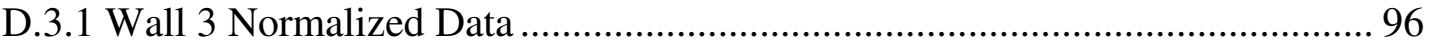

D.3.2 Wall Compression Test Specimens: Identical Data Sets Combined and

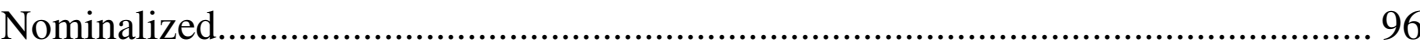

Appendix E - Consolidation Characteristics of Wall Compression Test Specimens...... 97

E.1 Top View of Wall Compression Specimens .................................................. 97

E.2 Side View of Wall Compression Specimens ................................................. 98

E.3 Recorded Visual Consolidation Characteristics of Wall Compression

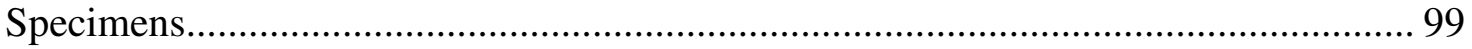

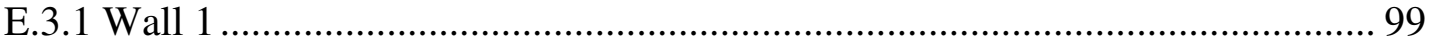

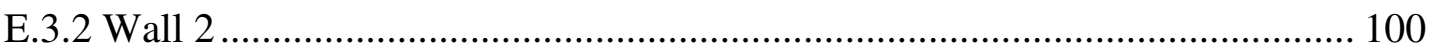

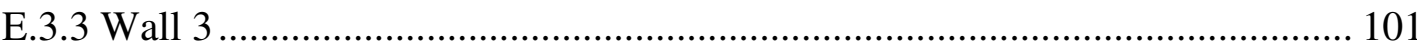

Appendix F - Consolidation Characteristics of Reinforcement Sections...................... 102

F.1 Pictures of Cross Sections through Reinforcement Layers............................... 102

F.2 Recorded Visual Consolidation Characteristics of Cross Section through

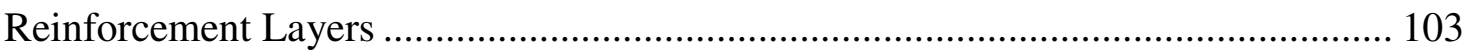

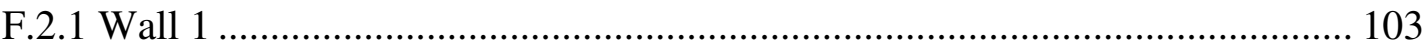

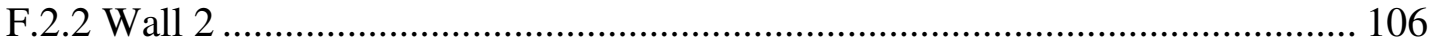

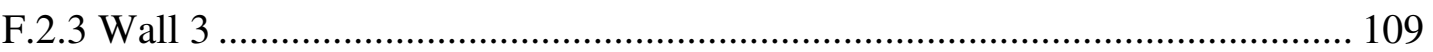

Appendix G - Rebar Pullout Investigation ........................................................ 111

viii 
G.1 Bond Strength of Grouts: Wall 4............................................................. 111

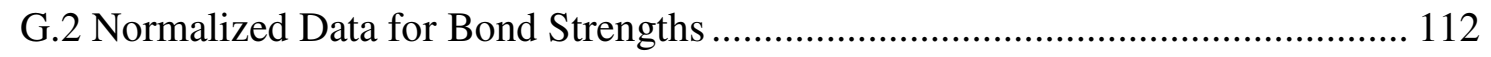

G.3 Required Development Length of Reinforcement ...................................... 113

G.4 Normalized Data for Development Length of Reinforcement .......................... 114

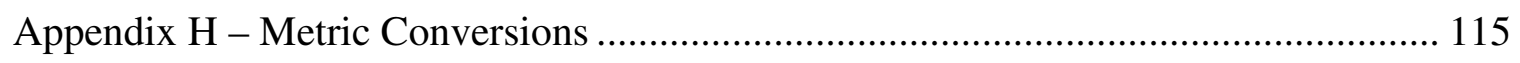




\section{LIST OF TABLES}

Table 1: Grout Proportions by Volume, Following Table 1 of ASTM C 476................. 19

Table 2: Proportions of Fly Ash and GGBFS Replacement of Portland Cement............ 20

Table 3: Number of Grout Test Specimens for Each Curing Process ........................... 21

Table 4: Grouting Schedule for Wall Experiment ................................................. 32

Table 5: Modified Shotcrete Core Consolidation Grades ............................................. 41

Table 6: Difference in Conventional Grout Compressive Strength Due to

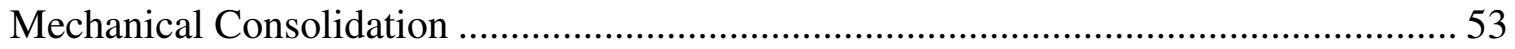

Table 7: Difference in Net Corrected Compressive Strength of the Wall

Experiment and Compression Experiment after 130 Days of Curing ............................ 54 


\section{LIST OF FIGURES}

Figure A: Rebar Pullout Test ..................................................................................... 11

Figure B: Grout Materials Mixing in Mechanical Mixer............................................... 22

Figure C: (1) Placing Grout in Cores of CMUs and (2) Dry Curing Grout

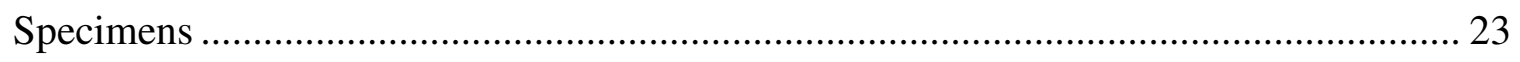

Figure D: (1) Wet Saw Cutting Specimens and (2) Final Grout Compression

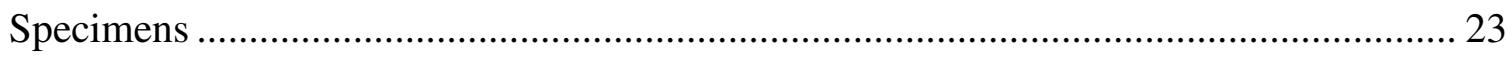

Figure E: (1) Capping of Grout Compression Specimens and

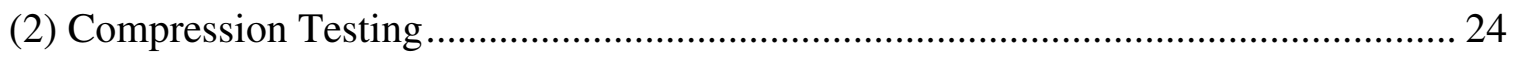

Figure F: (1) Wall Elevation and (2) Location of Cleanouts .......................................... 25

Figure G: (1) Horizontal Steel Placement and (2) Constructed Bond Beams .................. 26

Figure H: Plan View of Horizontal Reinforcement on Bond Beams................................ 26

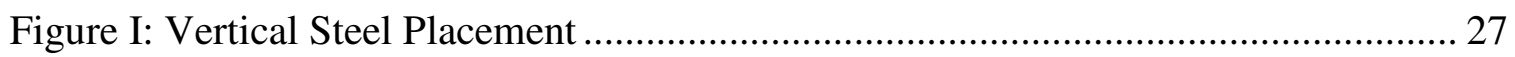

Figure J (1): Wall Configuration Elevations............................................................ 28

Figure J (2): Wall Configuration Elevations............................................................. 29

Figure K: Professional Masons Building Walls 1 and 2............................................. 30

Figure L: (1) Remixing Grout by hand and (2) Grout Funnel Leading into

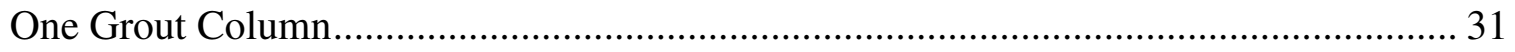

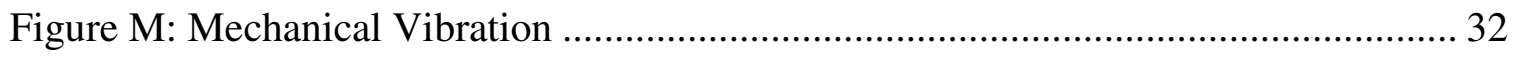

Figure N: (1) Fork Lift Tilting Wall and (2) Overhead Crane Lowering Wall ................ 33

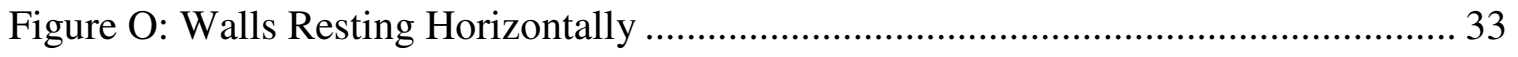

Figure P (1): Location of Specimens ............................................................................. 35 


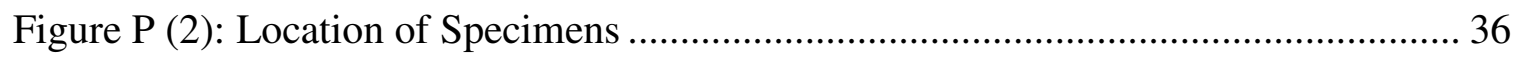

Figure Q: Cutting Walls: (1) Horizontally and (2) Vertically …………......................... 37

Figure R: Cutting through Reinforcement Using a Hand Saw ....................................... 37

Figure S: (1) Side View of Wall Compression Specimen and (2) Reinforcement

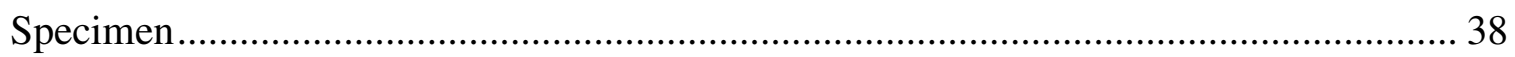

Figure T: (1) Chiseling Away Grout from Reinforcement and (2) Rebar

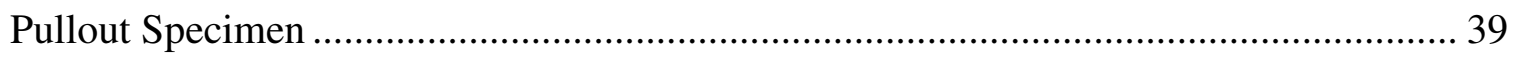

Figure U: Compression Testing of Wall Compression Test Specimen 2-1-2-6 ............... 40

Figure V: Top View of Wall Compression Specimen ................................................... 40

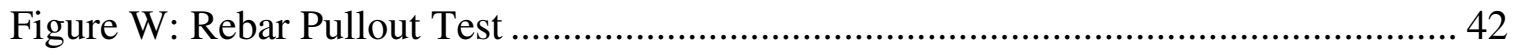

Figure X: Average Slump Flows of Experimental Grouts.............................................. 44

Figure Y: Slump Flow Picture of 70SF Batch 3 …………………............................. 45

Figure Z: Average Corrected Net Compressive Strength of Grouts from the Compression Experiment ....................................................................................... 46

Figure AA: Wall 1 Grout Specimen's Corrected Net Compressive Strength

Test Results ............................................................................................................. 48

Figure BB: Wall 2 Grout Specimen's Corrected Net Compressive Strength

Test Results .......................................................................................................... 49

Figure CC: Wall 3 Grout Specimen's Corrected Net Compressive Strength

Test Results ......................................................................................................... 50

Figure DD: Compressive Strength Test Results of the Identical Data Sets Combined

Figure EE: Average Corrected Net Compressive Strengths of Grout Mixtures along the Entire Height of the Wall from the Wall Experiment after 130 Days of Curing 
Figure FF: Average Consolidation Grade for Each Grout Mixture

Figure GG: Top View of Wall Compression Specimen 2-3-1-6 before

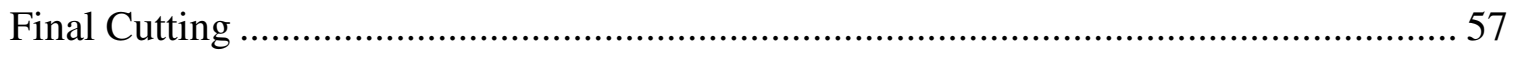

Figure HH: Side View of Wall Compression Specimen 2-1-2-2 ….............................. 58

Figure II: Cross Section of Reinforcement Specimen 1-1-2-B................................ 58

Figure JJ: Failure mode: Reinforcement Pull Out of Grout....................................... 59

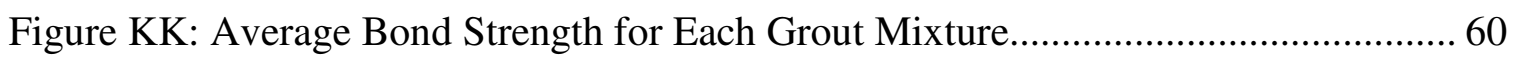

Figure LL: Average per Mixture of the Theoretical Development Lengths of Reinforcements Normalized to the Actual Embedment Lengths of the Rebar Pullout Specimens 


\section{LIST OF NOMENCLATURE}

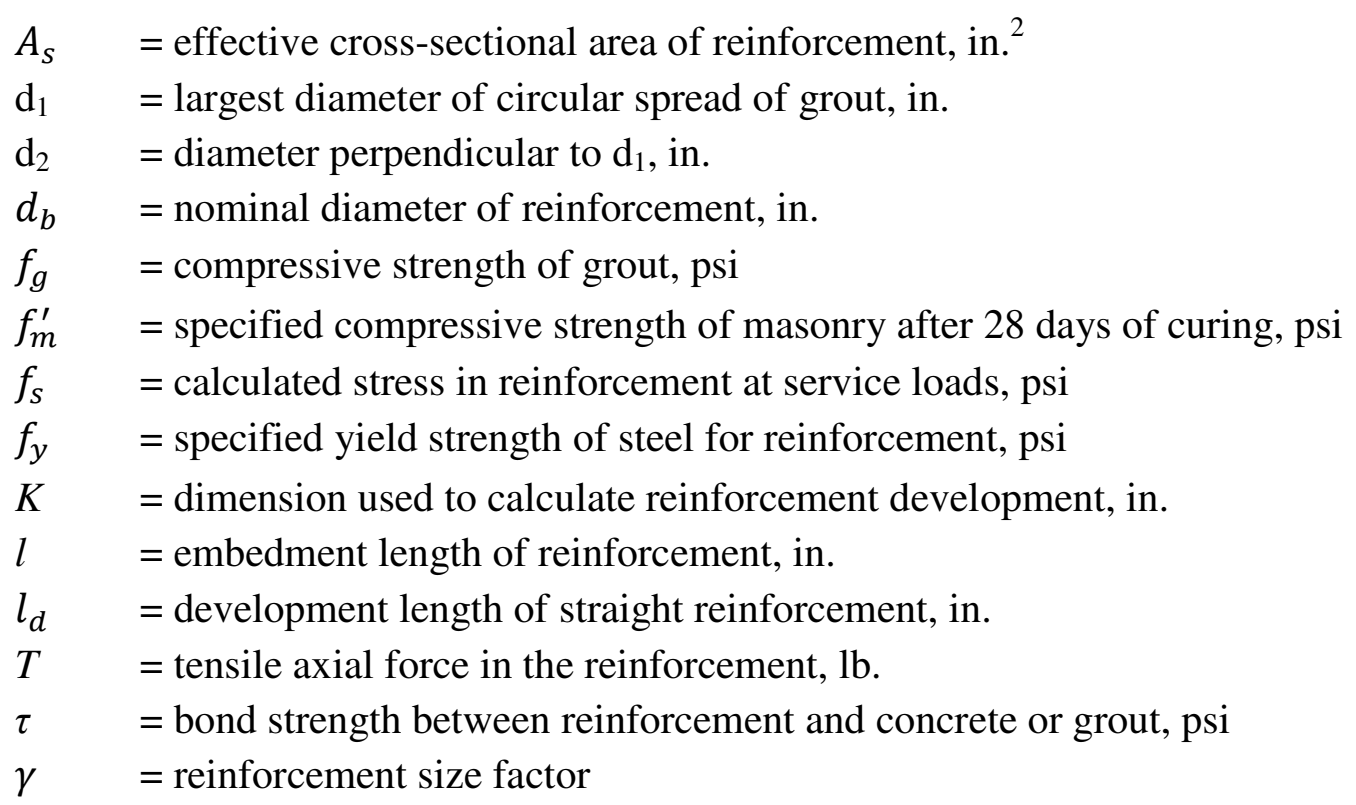




\subsection{INTRODUCTION}

The purpose of this thesis is to investigate whether high Type F fly ash and/or Ground Granulated Blast Furnace Slag (GGBFS) replacement of Portland cement in grout, without the use of admixtures and mechanical consolidation, can function as selfconsolidating grout. Self-consolidating grout with fly ash and/or GGBFS replacement can provide higher sustainability in masonry construction and also has important economic benefits. The replacement of cement with fly ash and/or GGBFS has the ability to promote sustainability, which is meeting present needs without compromising the ability of future generations to meet their needs. Partially replacing cement needed in grout with recycled material would lessen the demand for cement and in turn cement production. Lowering cement production would decrease the amount of fossil fuels and raw materials used for production and the by-products, such as carbon dioxide.

Grout, like concrete, is a cementitious material, typically used in hollow concrete masonry construction. In high seismic regions, structural designs require fully grouted walls. A fully grouted $8 \times 8 \times 16$ in. concrete masonry unit (CMU) contains approximately 52 percent grout based on the total volume. Since large amounts of grout are required, a more sustainable grout mixture would benefit the environment by reducing cement use. In addition, the reduction of cement use would increase the flowability of the grout mixture, potentially allowing the grout to become self-consolidating without the addition of an admixture. 
A self-consolidating grout mixture must:

- $\quad$ be fluid enough to flow and fill the forms under its own weight without any addition of external energy (i.e., vibration);

- remain homogeneous regardless of the distance it flows or the height of vertical discharge (i.e., no segregation of aggregates);

- $\quad$ flow through congested reinforcement and other confined spaces without losing its filling ability characteristics (Bonen and Shah 2005).

Self-consolidating grout in concrete masonry construction also has important economic benefits. Conventional grouting is labor-intensive and time-consuming due to the number of lifts required and use of a mechanical vibrator. Each grout lift needs to be vibrated before the next lift is placed to ensure proper consolidation, which is a timeconsuming process and can be a difficult task to perform in high reinforcement regions. Self-consolidating grout allows for proper consolidation without the use of a mechanical vibrator, saving time and money. 


\subsection{BACKGROUND}

Masonry grouts with high fly ash and/or GGBFS replacement of Portland cement have environmental benefits (2.1) and economic benefits (2.2). In order for the masonry grouts to function as self-consolidating grouts, the masonry grouts must meet the requirements of self-consolidating grout (2.3).

\subsection{Environmental Benefits}

Partially substituting fly ash and/or GGBFS for Portland cement in grout can help to reduce the cement industry's carbon footprint. Carbon footprint is the total amount of greenhouse gas emissions, including carbon dioxide, caused by an organization, person, or product. The primary sources of anthropogenic (produced by humans) carbon dioxide emissions are the combustion of fossil fuels, deforestation (and the associated reduction in carbon sequestration), unsustainable combustion of biomass, and the emission of mineral sources of carbon dioxide (Worrell et al. 2001). In the manufacturing process for cement, more than one fifth tonne of carbon dioxide is emitted for every tonne of cement produced. Sixty percent of the carbon dioxide emissions from cement production are due to the chemical process known as calcination, in which carbon dioxide is liberated from the decomposition of raw materials (mostly limestone) in a high temperature cement kiln (Mwangi and Baltimore 2009). The remaining 40\% of the carbon dioxide emissions are due to the combustion of fossil fuels (typically coal or petroleum coke) in the kiln. Currently, there are no viable remedies to reduce the carbon dioxide emission due to 
calcination, and measures to reduce the carbon dioxide emissions due to combustion (e.g., fuel substitution and energy efficiency improvements) are typically very costly.

In 1995, global cement production was estimated to be 1453 million metric tons and China led the way with the most cement production in the world, growing at 12.2 percent annually. Because of the importance of cement as a construction material and the geographic abundance of the main raw materials, cement is produced in virtually all countries. The cement industry contributes about 5 percent to global anthropogenic carbon dioxide emissions (Worrell et al. 2001). To help solve the emission problems, in 2006, California put into law (California Global Warming Solutions Act of 2006) a regulatory program to reduce carbon dioxide emissions to the 1990 levels, by the year 2020 (Mwangi and Baltimore 2009).

The long term goal should be to find a way to reduce the carbon dioxide emissions from each tonne of concrete produced. Many researchers have attempted to reduce the carbon dioxide emissions from the chemical process but there have not been viable solutions (Huntzinger et al. 2009). Therefore, the short time goal should be to reduce the amount of cement used in concrete and grout. Reducing the amount of cement in grout alone would not be appropriate because the strength of the grout would decrease and become inadequate. A partial substitute for the cement that would provide additional strength benefits would be needed. Currently, fly ash is used to replace Portland cement, more commonly, in low amounts of approximately 15 to 25 percent by weight, and GGBFS replaces cement at approximately 15 to 40 percent by weight. Fly ash and 
GGBFS replacements of Portland cement have already been recognized by the U.S. Green Building Council (USGBC) as a sustainable solution to help reduce the cement industry's carbon footprint. USGBC has developed the Leadership in Energy and Environmental Design (LEED) rating system which is a voluntary, consensus-based nation standard for developing high performance sustainable buildings. In order for a building to become a LEED certified project, a minimum of 40 points on a 110-point LEED rating system scale is needed for commercial buildings and 45 points on a 136point scale for homes. Fly ash and/or GGBFS replacement of Portland cement can contribute to points to reach this certification. In California there are many municipalities who require LEED certification on their newly constructed buildings (Kang and Kren 2007).

Fly ash is a fine-grained industrial waste particulate that comes from the combustion of coal. Fly ash can cause severe environmental problems if not disposed of correctly. The utilization of fly ash in concrete and grout instead of dumping the waste material in landfills is a solution to properly dispose of this material in a sustainable way. There are two types of fly ash that are defined by ASTM C 618 Standard Specification for Coal Fly Ash and Raw or Calcined Natural Pozzolan for Use in Concrete; Type C and Type F. Type F fly ash is more commonly used, so this thesis will focus on the use of Type F fly ash. Fly ash, a pozzolan, creates a pozzolanic reaction when combined with calcium hydroxide in the presence of water to form cementitious properties. Fly ash has 
a slower development of strength than that of cement and acts as a plasticizer, improving the workability of the grout mixture.

Blast furnace slag is a by-product of iron and steel production. Granulated blast furnace slag is formed when molten blast furnace slag is quenched in water, and GGBFS is formed by subsequent grinding, reducing the particle size to the same fineness of cement. There are three types of GGBFS that are defined by ASTM C 989 Standard Specification for Slag Cement for Use in Concrete and Mortars; Grade 120, Grade 100, and Grade 80. This thesis will focus on Grade 100. GGBFS hydrates like Portland cement, but has a slower development of strength than that of cement and improves the workability of the grout mixture.

\subsection{Economic Benefits}

In high seismic zones, structural designs require fully grouted walls for hollow concrete masonry. Hollow concrete masonry walls typically have close spacing of reinforcement due to high seismic demands. Grout is required to flow into all areas of the highly reinforced masonry wall to bind the reinforcement and masonry units together. For conventional grout, a mechanical vibrator is required for consolidation to eliminate air voids and to help ensure sufficient bond strength between materials. The vibrator may be difficult to get into small spaces because of the closely spaced reinforcement (Khayat 1999). Another feature of conventional grouting is pouring the grout at different heights or lifts: low lift and high lift. A low lift is approximately $4 \mathrm{ft}$. high and a high lift is approximately $12 \mathrm{ft}$. high. Grouting a low lift normally contains less error of 
consolidation (fewer voids) than a high lift when using a mechanical vibrator, but it takes several low lifts to reach the height of the high lift. Each lift must be consolidated before the next lift is placed, which takes more time. For high lifts, consolidation is harder to achieve, so the labor requires a more skilled worker. The processes of vibrating multiple lifts are labor-intensive and time-consuming which increases costs.

A self-consolidating grout would cut costs by allowing the grout to be poured from high lifts assuming it properly consolidates under its own weight without the use of a mechanical vibrator. Self-consolidating grouts, with the use of admixtures, already exist and are available commercially (Ryan and Farnsworth 2003). Admixtures in selfconsolidating grout are primarily used to increase the workability of the grout mixture so that less water is required (thereby increasing the strength of the grout). Admixtures are also used for various effects, including, controlled setting and hardening, improved strength, and better durability. Although admixtures commonly benefit a grout mixture, they can occasionally cause incompatibility problems due to their interaction with cement or other admixtures, can result in application errors in the field, and are relatively expensive (Rixom and Mailvaganam 1999). High replacement of Portland cement with fly ash and/or GGBFS may increase the grout's workability so that admixtures are not needed.

\subsection{Requirements of Self-Consolidating Grout}

According to ASTM C 476 Standard Specification for Grout for Masonry; a grout may qualify as a self-consolidating grout, the grout mixture needs to provide a slump 
flow of 24 to 30 inches (determined by ASTM C 1611 Standard Test Method for Slump Flow of Self-Consolidating Concrete), a Visual Stability Index (VSI) of not greater than one (determined by Appendix XI of ASTM C 1611), and a minimum compressive strength of 2000 psi after 28 days of curing (in accordance with ASTM C 1019 Standard Test Method for Sampling and Testing Grout). The slump flow test and VSI help to assure that the self-consolidating grout is fluid enough to flow under its own weight without vibration while remaining homogeneous. In addition, a self-consolidating grout must be able to flow through congested reinforcement while still fulfilling the strength requirements of conventional grout.

\subsubsection{Compressive Strength}

Initial research, Phase 1 (Mwangi and Baltimore 2009) and Phase 2 and 3 (Bradfield 2011), investigated the development of compressive strengths of grouts with partial Portland cement replacement with Type F fly ash, and combinations of Type F fly ash and GGBFS Grade 100. The compressive strengths were compared with the minimum compressive strength of 2000 psi after 28 days of curing prescribed by building code (IBC 2009) and ASTM C 476. The results of the testing indicated that partial fly ash and/or GGBFS replacement grout is a viable alternative to traditional grout. Phase 1 testing (Mwangi and Baltimore 2009), fly ash replacement of cement, included 180 specimens that were formed in the cells of hollow CMU, cured in both wet and dry conditions, and sawn cut to $4 \times 4 \times 8$ inches (nominal). The cured specimens were tested after 7, 14, 28, 42, and 56 days. The percentages of Portland cement replaced were 
$0 \%, 20 \%, 30 \%, 40 \%, 50 \%$, and $60 \%$. The specimens were prepared and tested in conformance to ASTM C 1019. The results of the testing showed that grouts with $20 \%$ and 30\% replacement (by weight) could be treated as traditional grout. Grout with $40 \%$ and 50\% replacement (by weight) requires a longer curing period to reach compressive strengths. The $60 \%$ grout replacement did not appear to meet strength standards. The longer cure period is characteristic of the pozzolanic nature of fly ash solidification. Thus in Phase 2 (Bradfield 2011), compression tests were again performed for similar specimens with fly ash replacement of cement, however longer cure periods were investigated. In Phase 2, 180 specimens were tested after 7, 14, 28, 42, 56 and 180 days. The percentages of Portland cement replaced were $0 \%, 20 \%, 30 \%, 40 \%, 50 \%$, and $60 \%$. The specimens were prepared and tested in conformance to ASTM C1019. The results of Phase 2 testing confirmed, from Phase 1, that grouts with 20\% and 30\% replacement (by weight) could be treated as traditional grout. Grout with $40 \%$ and 50\% replacement (by weight) required a longer curing period (42 days) to reach the required 28 day compressive strengths. The $60 \%$ grout replacement required 56 days to meet minimum strengths and 180 days to exceed these strengths. The Phase 3 testing (Bradfield 2011) included both fly ash and GGBFS for the replacement of Portland cement. Testing was after 7, 14, 28, 42, 56 and 180 days. The percentages of Portland cement replaced were $50 \%, 60 \%, 70 \%$ and $80 \%$. The amount of fly ash replacement was kept constant at $25 \%$ and the amount of GGBFS was varied to meet the total replacement percentage. The results showed that all percentages of Portland cement replacement required a 42 day 
cure time to reach compressive strengths. This research demonstrated that fly ash and/or GGBFS replacement of Portland cement could satisfy the compressive strength requirements of ASTM C 476 with a longer duration of curing time.

\subsubsection{Consolidation Characteristics}

Research by the National Concrete Masonry Association (NCMA) confirmed proper consolidation from self-consolidating grout that contained admixtures (Greenwald et al. 2006). The research documented the behavior using visual assessment throughout the height of $12.67 \mathrm{ft}$. masonry wall assemblies. Three sample walls, $12.67 \mathrm{ft}$. high, were constructed with separate vertically aligned grout columns intended to evaluate the influence of mechanical consolidation and placement of horizontal reinforcement. The grouts, which came from a local supplier, were pumped in one $12.67 \mathrm{ft}$. high lift. The conventional grout used a mechanical vibrator to consolidate the grout, while the selfconsolidating grout did not. After 14 days of curing the walls were cut into sections at various wall heights and the grouts were visually inspected for the presence of any segregation and air voids, particularly under the horizontal reinforcement and mortar fins. Specific conclusions were (1) all specimens indicated no visible segregation; and (2) all specimens exhibited complete grout fill under and around reinforcement and mortar fins. This research demonstrated that self-consolidating grout could achieve the same quality of consolidation as conventional grout. 


\subsubsection{Bond Strength}

Stress design of reinforced masonry uses the grout, CMU, and mortar together to resist the compression forces, while steel reinforcement resists the tension forces. For designed tension forces to be resisted by the reinforcement there must be a transfer of forces, or bond, between the grout and reinforcement. Rebar pullout tests, as shown in Figure A, determine the stress in reinforcement, $f_{\mathrm{s}}$, at a service load, $T$, caused by the bond.

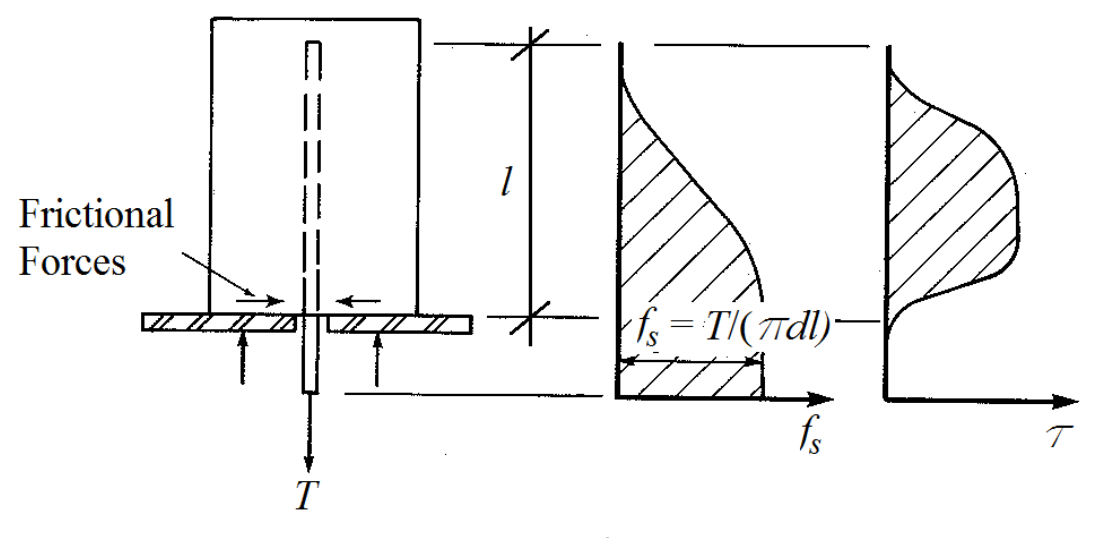
(a) Test Method
(b) Bar Stress
(c) Bond Stress

Figure A: Rebar Pullout Test

Source: Modified from Wight and MacGregor 2009 
The bond strength, $\tau$, is equal to the calculated stress in reinforcement, $f_{\mathrm{s}}$. From the rebar pullout test, the ultimate axial load, $T$, can used to determine the bond strength between the grout and reinforcement, given in the equation

$$
\tau=\frac{T}{\pi d_{b} l}
$$

Where

$$
\begin{aligned}
& \tau \text { is the bond strength (psi), } \\
& T \text { is the tensile axial force in the reinforcement (lb.), } \\
& d_{b} \text { is the nominal diameter of reinforcement (in.), and } \\
& l \quad \text { is the embedment length (in.). }
\end{aligned}
$$

According to the provisions of ACI 318, the embedment length of reinforcement for sufficient anchorage is inversely proportioned to the square root of the compressive strength, implying that the bond strength should be linearly proportional to the square root of compressive strength (Foroughi, Dilmaghani, and Famili 2008), as shown in the equation

$$
\tau=12.043 \sqrt{f_{g}}
$$

Where $\quad \tau$ is the bond strength (psi), and

$f_{g}$ is the compressive strength of grout (psi).

Equation 2 is applicable for conventional grouts, while a self-consolidating grout may not have the same relationship between the compressive strength and bond strength. By preforming separate tests, compression and rebar pullout, the relationship between the compressive strength and bond strength can help determine the validity of Equation 2 applied to self-consolidating grouts. 
Research using self-consolidating concrete has confirmed that adequate bond strength could be achieved and had similar characteristics to that of conventional concrete (Foroughi, Dilmaghani, and Famili 2008). The research investigated the bond between self-consolidating concrete and steel reinforcement by conducting rebar pullout tests from cubic specimens. The self-consolidating concrete was compared to conventional concrete that was mechanically vibrated. The results showed (1) that the selfconsolidating concrete specimens generated a higher bond to the reinforcement than conventional concrete; and (2) the correlation between bond strength and compressive strength of conventional concrete was more consistent.

The design of reinforced masonry structures requires that the reinforcement must be anchored so as to fully develop the reinforcing bar to its yield stress. For full development to be achieved, a minimum development length, $l_{\mathrm{d}}$, of the reinforcing bar must be provided through anchorage to the grout. The code (Masonry Building Code 2008) defines a minimum development length for reinforcement embedded in grout, shown in the equation

$$
l_{d}=\frac{0.13 d_{b}^{2} f_{y} \gamma}{K \sqrt{f_{m}^{\prime}}}
$$

Where $\quad l_{d}$ is the development length of straight reinforcement (in.),

$d_{b}$ is the nominal diameter of reinforcement (in.),

$f_{y}$ is the specified yield strength of steel for reinforcement (psi),

$\gamma$ is the reinforcement size factor (dimensionless),

$K$ is the dimension used to calculate reinforcement development (in.), and

$f_{m}^{\prime}$ is the specified compressive strength of masonry after 28 days of curing (psi). 


\subsection{LITERATURE REVIEW}

There has been many research papers related to this thesis that have provided similar conclusions to each other. The previous research papers described in the background and the following literature review section provides enough evidence to validate the value for this thesis.

The report "Evaluation of Self-Consolidating Concrete for Bridge Structure Applications" evaluated self-consolidating concrete for the homogeneity of the mix (Horta 2005). The purpose was to compare the consolidation properties of different selfconsolidating concrete mixtures; half of the mixtures were consolidated with a vibrator and the other half were not. Each self-consolidating concrete mixture was poured into wall panel formwork with vertical and horizontal reinforcement. After curing, the selfconsolidating concrete was evaluated on (1) surface finish, (2) compressive strength, and (3) aggregate distribution from cut specimens. (1) From visual inspection of the surface finish, the diameter of air voids greater than or equal to $1 / 8 \mathrm{in}$. were recorded. The results showed that the self-consolidating concrete without vibration experienced more air voids than the self-consolidating concrete with vibration. (2) Concrete compression tests evaluated the compressive strength of three inch diameter cores from the top, middle, and bottom of the walls. There were no significant differences in compressive strength between the self-consolidating grouts that were vibrated and those that were not vibrated.

(3) The walls were cut vertically into thirds and through visual inspection there were no segregations of aggregates in any mixture and were no significant differences of air voids 
between the self-consolidating concrete with and without mechanical vibration.

The report "Evaluating the Static Segregation Resistance of Hardened SelfConsolidating Concrete using Image Processing Technology" compared the segregation of aggregates from cut sections of cured self-consolidating concrete through the Hardened Visual Stability Index and an image processing technology (Fang and Labi 2006). The Hardened Visual Stability Index is a varying visual rating scale of aggregate segregation on a scale of 0 to $4: 0$ (stable), 1 (stable with slight variance in size), 2 (unstable), and 3 (unstable and clearly segregated aggregates). The image processing technology used a binary image of light colors and complex algorithms to evaluate a sample in terms of the Hardened Visual Stability Index. The findings concluded that the image processing technology was accurate for the report, but further field tests are needed to completely validate the reliability of the algorithms. Also, the Hardened Visual Stability Index may face errors in human judgment, subjectivity of ratings, and low efficiency.

The report "The Feasibility of Using Self-Consolidating Concrete (SCC) in Drilled Shaft Applications" compared conventional drilled shaft concrete and selfconsolidating concrete in a drilled shaft application (Hodgson et al. 2004). Drilled shafts were created with congested reinforcement and filled with either conventional drilled shaft concrete or self-consolidating concrete. The piles were exhumed and cross sections were cut to visually observe the segregation of aggregates and the presence of air voids near the reinforcement. The study concluded that the self-consolidating concrete and 
conventional drilled shaft concrete mixtures showed no significant signs of aggregate segregation throughout the cross sections. The self-consolidating concrete contained air voids from $1 / 16$ to $1 / 8$ inches in diameter. 


\subsection{EXPERIMENT}

Two experiments were conducted to investigate if high Portland cement replacement grout could be characterized as self-consolidating grout. The experimental grout mixtures used fly ash, or fly ash and GGBFS in combination, as the replacements for Portland cement. No admixtures were added to any of the grout mixtures. The experimental grouts were compared to a baseline grout mixture (conventional grout: mechanical consolidation and no Portland cement replacement). The same grout mixtures were used for both experiments so that they could be linked to each other.

The first experiment, The Compression Experiment, investigated the performance of the potential self-consolidating grouts through compressive strengths of individually grouted CMU at various curing times. The second experiment, The Wall Experiment, investigated the behavior and performance of the potential self-consolidating grouts (experimental grouts) throughout the height of a high lift wall assembly through visual assessment and physical evaluation. Specifically, the research focused on three different aspects of consolidation by comparing the potential self-consolidating grouts to conventional grouted masonry: a visual inspection of the flow characteristics around the mortar fins and reinforcement in the CMU cells, an evaluation of compressive strengths after 130 days of curing, and an evaluation of the bond between the reinforcements and grouts (rebar pullout tests).

All tests were conducted at the High Bay Laboratory and Concrete Laboratory in the Architectural Engineering department of the College of Architecture and 
Environmental Design at the California Polytechnic State University in San Luis Obispo, California.

\subsection{Materials}

Materials used in the investigation were:

- Portland cement Type II \& V complying with ASTM C 150

- Coal fly ash Type F complying to ASTM C 618

- Ground granulated blast furnace slag (GGBFS) Grade 100 complying with ASTM C 989

- Type S masonry mortar complying with ASTM C 270

- Hollow concrete masonry units (CMUs) complying with ASTM C 90

- Coarse aggregate (3/8 in.) pea gravel complying with ASTM C 404

- Fine aggregate washed concrete sand complying with ASTM C 404

- \#3 and \#5 Deformed Rebar complying with ASTM A 615

- Potable water

\subsection{Grout Mixture Proportions}

The grout mixture proportions including fine aggregate, coarse aggregate (3/8 in. pea gravel), total cementitious material, and water remained constant for all of the grout mixtures. The grout proportions, by volume, followed the upper bound on aggregates from Table 1 of ASTM C 476 and can be seen in Table 1. 
Table 1: Grout Proportions by Volume, Following Table 1 of ASTM C 476

\begin{tabular}{|c|c|c|c|c|}
\hline \multicolumn{5}{|c|}{ Grout Proportions by Volume } \\
\hline \multirow[t]{2}{*}{ Type } & \multirow{2}{*}{$\begin{array}{c}\text { Parts by } \\
\text { Volume of } \\
\text { Cementitious } \\
\text { Material }\end{array}$} & \multirow{2}{*}{$\begin{array}{c}\text { Parts by Volume } \\
\text { of Hydrated } \\
\text { Lime or Lime } \\
\text { Putty }\end{array}$} & \multicolumn{2}{|c|}{$\begin{array}{c}\text { Aggregate, } \\
\text { Measured in a Damp, Loose } \\
\text { Condition }\end{array}$} \\
\hline & & & Fine & Coarse \\
\hline $\begin{array}{l}\text { Coarse } \\
\text { Grout, } \\
(\max 3 / 8 \\
\text { in. agg.) }\end{array}$ & 1 & 0 & $\begin{array}{l}3 \text { times the sum } \\
\text { of the volumes of } \\
\text { cementitious } \\
\text { materials }\end{array}$ & $\begin{array}{c}2 \text { times the sum } \\
\text { of the volumes of } \\
\text { cementitious } \\
\text { materials }\end{array}$ \\
\hline
\end{tabular}

The only factor in the grout proportions that changed between each mixture was within the cementitious materials. There were three types of cementitious material tested: no-replacement of Portland cement, Type F fly ash replacement of Portland cement, and Type F fly ash and GGBFS Grade 100 replacement of Portland cement. The no-replacement grout, referred to as conventional grout or the "base mix design", represents the grout commonly used in industry and which requires vibration for consolidation.

There were three grout mixtures within both the fly ash replacements $(50 \mathrm{~F}, 60 \mathrm{~F}$, and 70F), and fly ash and GGBFS replacements (60SF, 70SF, and 80SF), known as the experimental grouts. The proportions for cementitious material for the fly ash and/or GGBFS replacement used are shown in Table 2. 
Table 2: Proportions of Fly Ash and GGBFS Replacement of Portland Cement

\begin{tabular}{|c|c|c|c|}
\hline \multirow{2}{*}{ Type F Fly Ash and GGBFS Replacements } \\
\cline { 2 - 4 } Test Name & $\begin{array}{c}\text { Cement } \\
\text { (\% Vol. })\end{array}$ & $\begin{array}{c}\text { Fly Ash } \\
(\% \text { Vol. })\end{array}$ & $\begin{array}{c}\text { GGBFS } \\
(\% \text { Vol. })\end{array}$ \\
\hline $50 \mathrm{~F}$ & 50 & 50 & 0 \\
\hline $60 \mathrm{~F}$ & 40 & 60 & 0 \\
\hline $70 \mathrm{~F}$ & 30 & 70 & 0 \\
\hline $60 \mathrm{SF}$ & 40 & 15 & 45 \\
\hline $70 \mathrm{SF}$ & 30 & 17.5 & 52.5 \\
\hline $80 \mathrm{SF}$ & 20 & 20 & 60 \\
\hline $100 \mathrm{C}$ & 100 & 0 & 0 \\
\hline
\end{tabular}

ASTM C 476 specifies that the proportion of water required for a conventional grout must provide a slump of 8 to 11 inches, as determined by ASTM C 143 Standard Test Method for Slump of Hydraulic-Cement Concrete. The "base mix design" was determined to have a water-to-cement ratio of 1.375 by volume, which provided an average slump of 9.75 inches, as determined following ASTM C 143. The water-tocementitious materials ratio was kept constant at 1.375 by volume for all of the grout mixtures.

According to ASTM C 476, in order for the experimental grouts to qualify as selfconsolidating, the grout mixtures needed to provide a slump flow of 24 to 30 inches (determined by ASTM C 1611), a Visual Stability Index (VSI) of not greater than 1 (determined by Appendix XI of ASTM C 1611), and a minimum compressive strength of 
2000 psi after 28 days of curing (in accordance with ASTM C 1019).

\subsection{The Compression Experiment}

Seven grout mixtures were tested: conventional grout, $50 \%, 60 \%$, and $70 \%$ fly ash replacement of cement, and 60\%, 70\%, and $80 \%$ fly ash and GGBFS replacement of cement, as shown in Table 2. The grout samples were dry cured within the cells of 8x8x16 in. CMUs. Three grout specimens per mixture were tested after 7, 14, 28, 42, 56, and 130 days of curing, as shown in Table 3. Altogether, a total of 126 specimens were tested for The Compression Experiment.

Table 3: Number of Grout Test Specimens for Each Curing Process

\begin{tabular}{|c|c|c|c|c|c|c|c|c|c|}
\hline \multicolumn{10}{|c|}{ Number of Grout Test Specimens for Each Curing Process } \\
\hline \multirow{3}{*}{$\begin{array}{c}\text { Test } \\
\text { Name }\end{array}$} & \multirow{2}{*}{\multicolumn{3}{|c|}{ Cementitious Material }} & \multicolumn{6}{|c|}{ Test Age (Days) } \\
\hline & & & & 7 & 14 & 28 & 42 & 56 & 130 \\
\hline & $\begin{array}{c}\text { Cement } \\
(\% \text { Vol.) }\end{array}$ & $\begin{array}{l}\text { Fly Ash } \\
\text { (\% Vol.) }\end{array}$ & $\begin{array}{l}\text { GGBFS } \\
(\% \text { Vol.) }\end{array}$ & \multicolumn{6}{|c|}{ Number of Specimens } \\
\hline $100 \mathrm{C}$ & 100 & 0 & 0 & 3 & 3 & 3 & 3 & 3 & 3 \\
\hline $50 \mathrm{~F}$ & 50 & 50 & 0 & 3 & 3 & 3 & 3 & 3 & 3 \\
\hline $60 \mathrm{~F}$ & 40 & 60 & 0 & 3 & 3 & 3 & 3 & 3 & 3 \\
\hline $70 \mathrm{~F}$ & 30 & 70 & 0 & 3 & 3 & 3 & 3 & 3 & 3 \\
\hline 60SF & 40 & 15 & 45 & 3 & 3 & 3 & 3 & 3 & 3 \\
\hline $70 \mathrm{SF}$ & 30 & 17.5 & 52.5 & 3 & 3 & 3 & 3 & 3 & 3 \\
\hline 80SF & 20 & 20 & 60 & 3 & 3 & 3 & 3 & 3 & 3 \\
\hline \multicolumn{10}{|c|}{ Total Number of Specimens $=126$} \\
\hline
\end{tabular}

Seven grout batches were prepared, one for each of the grout mixtures listed in Table 3. The material proportions were batched by volume into five gallon buckets and mixed in a mechanical mixer in accordance with ASTM C 476 as seen in Figure B. Each mix was batched only one time and a slump test, following ASTM C 143, was provided 
for the conventional grout or a slump flow test, following ASTM C 1611, was provided for the experimental grouts (shown in Appendix A).

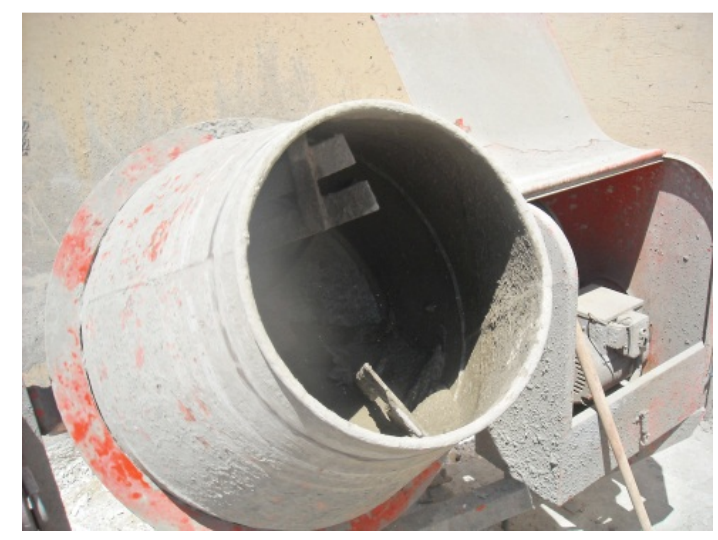

\section{Figure B: Grout Materials Mixing in Mechanical Mixer} Source: Author Photo

Grout specimens were made in accordance with ASTM C 1019, with one exception: the grouts were poured into the cores of 8x8x16 in. CMUs to form the specimens, as seen in Figure $\mathrm{C}(1)$, rather than constructing a grout mold using four CMUs. This exception was made in order to save space and mimic the same water absorption the grout experiences while curing in the core of the CMU, yet still providing the absorptive mold requirement in ASTM C 1019. The grouted CMUs were dry cured, complying with ASTM C 157 Standard Test Method for Length Change of Hardened Hydraulic-Cement Mortar and Concrete, as shown in Figure C(2). 

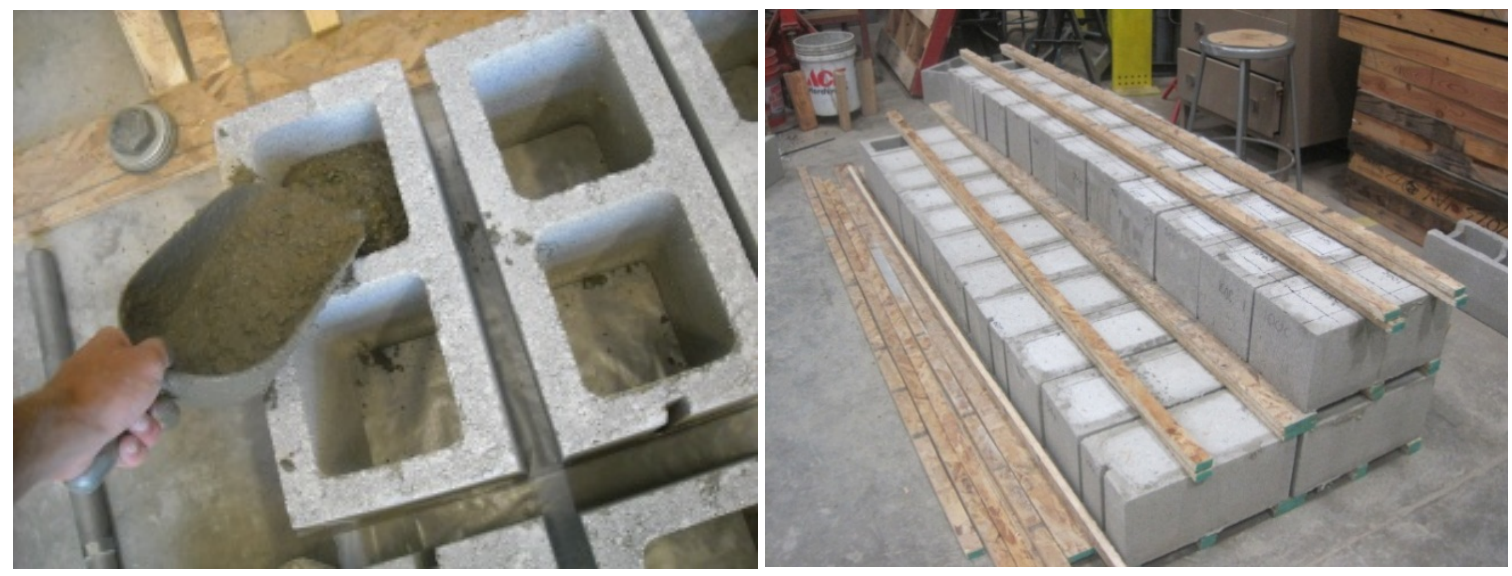

\section{Figure C: (1) Placing Grout in Cores of CMUs and (2) Dry Curing Grout Specimens}

Source: Author Photos

One day prior to testing, the compression test specimens were made by saw

cutting the grout specimens to $4 \times 4 \times 8$ in. (nominal) by using a 20 in. diameter diamond blade wet saw, satisfying the dimensional requirements of ASTM C 1019 as shown in

Figure D.
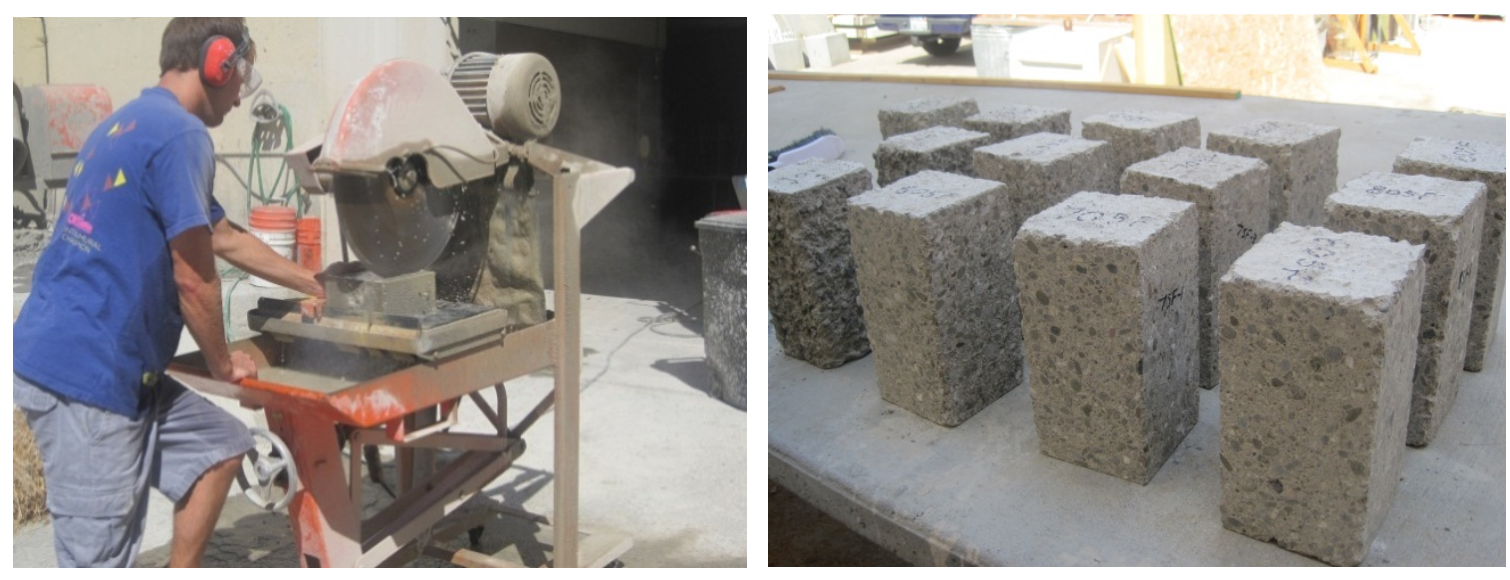

Figure D: (1) Wet Saw Cutting Specimens and (2) Final Grout Compression Specimens

Source: Author Photos

Performance of No Vibration/No Admixture Masonry Grout Containing High Replacement of Portland Cement with Fly Ash and Ground Granulated Blast Furnace Slag 
After cutting, the samples were returned to their curing environment until testing. The specimens were capped in accordance to ASTM C 1552 Standard Practice for Capping Concrete Masonry Units, Related Units and Masonry Prisms for Compression Testing, and tested in compression in accordance with ASTM C 1019 as shown in Figure E.
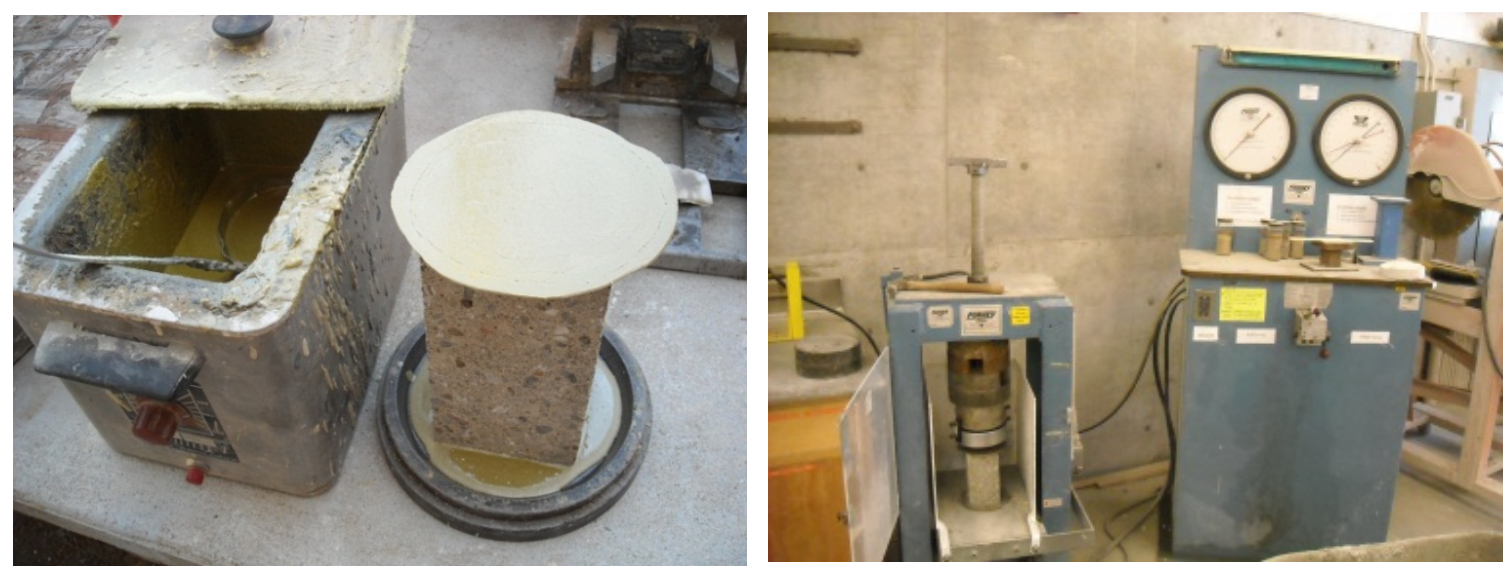

Figure E: (1) Capping of Grout Compression Specimens and (2) Compression Testing

Source: Author Photos

\subsection{The Wall Experiment}

\subsubsection{Wall Design}

Four walls were constructed by professional masons in one lift for the Wall

Experiment. All of the walls were built with a running bond using double square core, single wythe $8 \times 8 \times 16$ in. CMU, and 19 courses high for a total height of $12.67 \mathrm{ft}$., as seen in Figure $F(1)$. Full mortar bedding was used to prevent the grout from flowing into adjacent grout columns. Cleanouts were provided in the first course of all the columns to be grouted as shown in Figure $F(2)$.

Performance of No Vibration/No Admixture Masonry Grout Containing High Replacement of Portland Cement with Fly Ash and Ground Granulated Blast Furnace Slag 

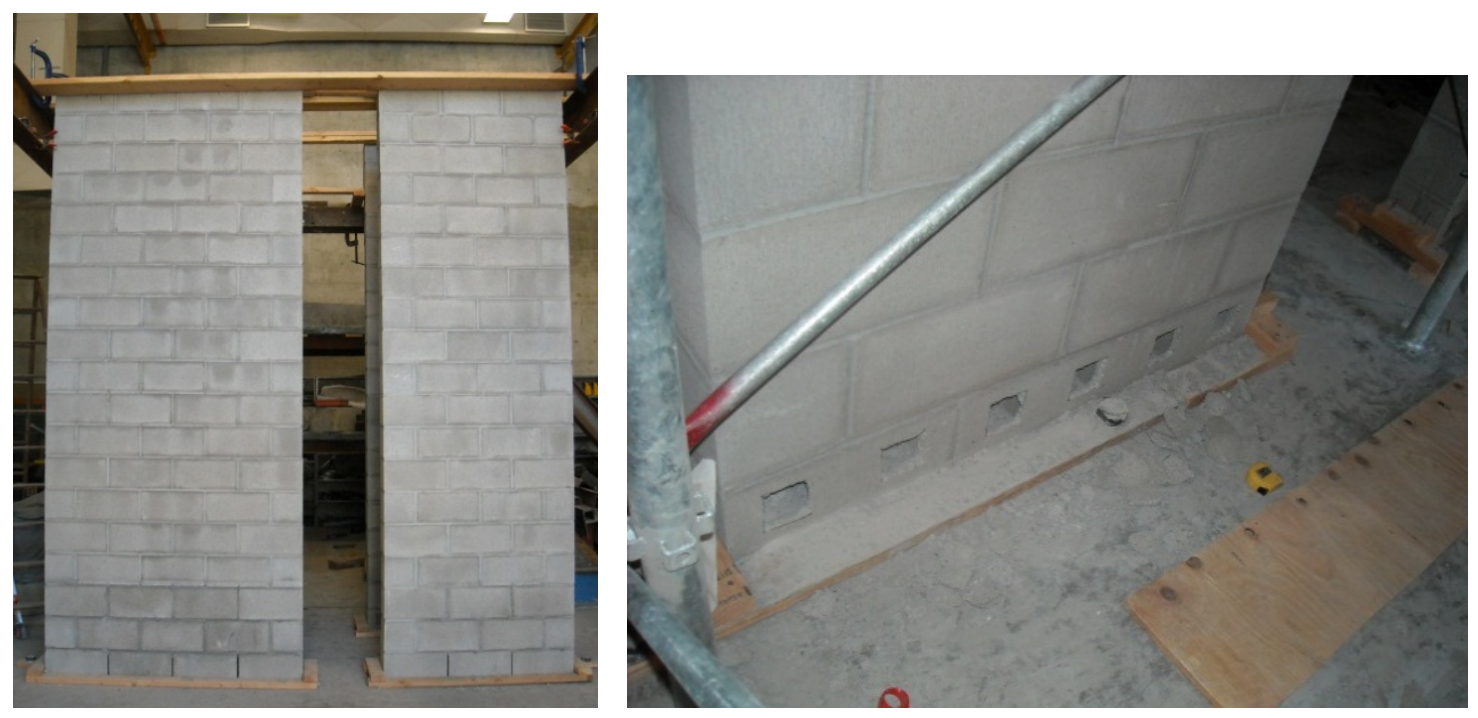

\section{Figure F: (1) Wall Elevation and (2) Location of Cleanouts}

Source: Author Photos

The walls were labeled 1, 2, 3, and 4. Walls 1, 2, and 3 were used for the evaluation of compression strengths and visual inspection of the flow characteristics around the mortar fins and reinforcement of the grouts at varying heights along the wall. Wall 4 was used for the evaluation of the bond between the reinforcements and grouts at varying heights along the wall.

Walls 1, 2, and 3 were 4.0 feet wide, and consisted of six grout columns. The walls had two No. 5 horizontal reinforcement bars placed at bond beam CMUs at 2.0 feet on center vertically, as shown in Figure G(1). The bond beams were constructed on-site by cutting and chipping away typical CMUs as seen in Figure G(2). 

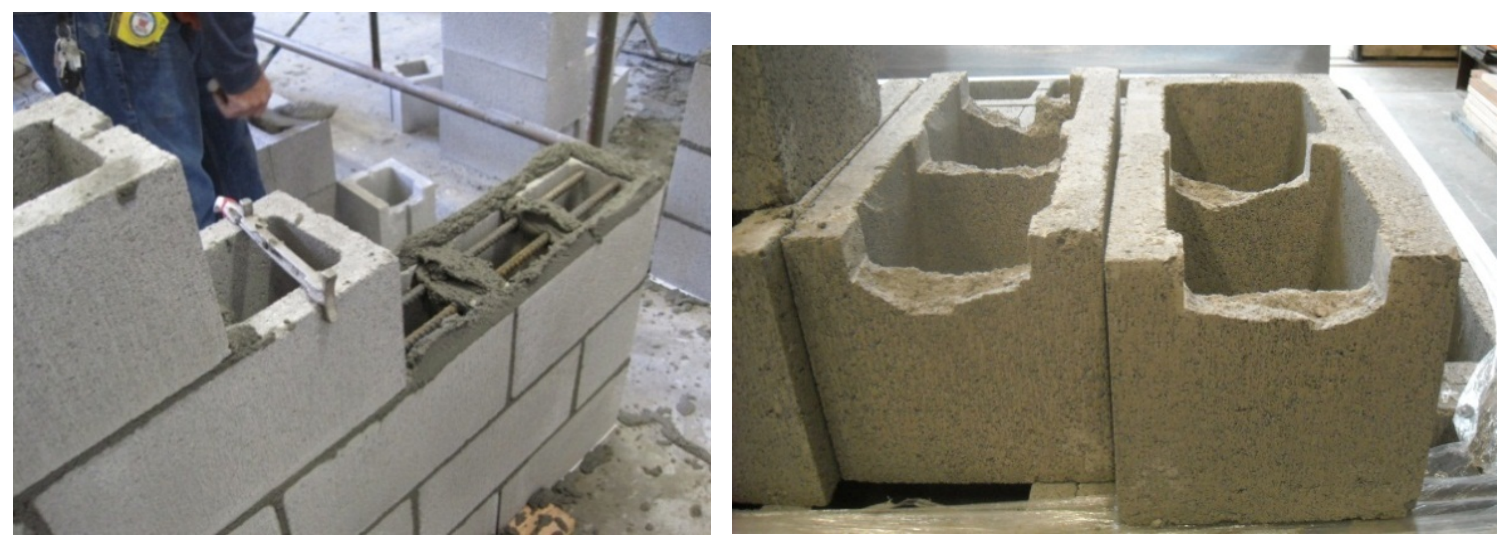

Figure G: (1) Horizontal Steel Placement and (2) Constructed Bond Beams

Source: Author Photos

The two No.5 reinforcement bars at each reinforcement layer were spaced equally, resulting in three spaces approximately $1 \frac{1 / 4}{4}$ in. wide, as shown in Figure H.

(2) \#3

Reinforcement at $2 \mathrm{ft}$. O.C.

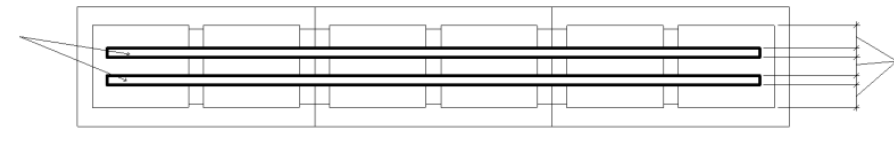
$\sim 1 \frac{1 / 4}{\text { in. equal }}$ spacing, Typ. Vertically

\section{Figure H: Plan View of Horizontal Reinforcement on Bond Beams} Source: Author Diagram

Wall 4 was $5.33 \mathrm{ft}$. wide, and consisted of eight grout columns. The wall had one No. 3 vertical reinforcing bar placed as close to the middle of each grout column as possible, throughout the entire height of the column, as shown in Figure I. 


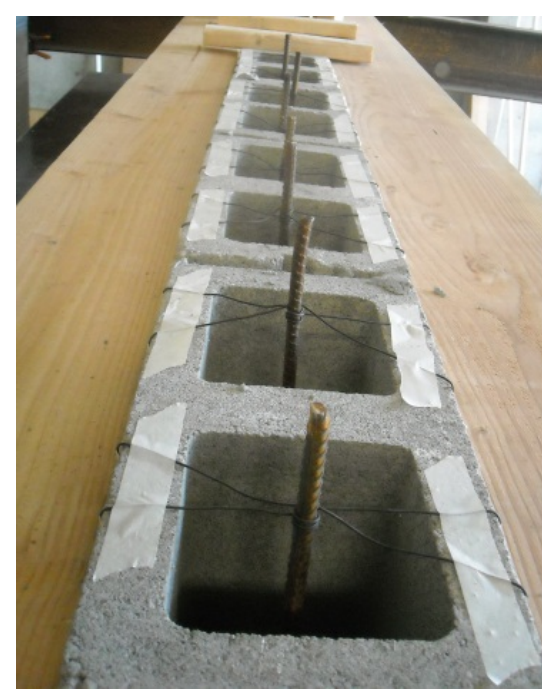

Figure I: Vertical Steel Placement

Source: Author Photo

Figures $\mathrm{J}(1)$ and $\mathrm{J}(2)$ illustrate each wall, indicating corresponding grout type, reinforcement locations, and mechanical consolidation. Fly ash replacement grouts were used in wall 1, fly ash and GGBFS replacement grouts used in wall 2, conventional grout used in wall 3, and all grouts used in wall 4. For walls 1 and 2, each mixture of grout was used in two grout columns. For wall 3, three grout columns were vibrated and two were not. The first grout column in wall 3 (Column ID: 3-1-1) was not properly mechanically vibrated, so that column was ignored in the experiment. For wall 4, each mixture of grout was used in one grout column. 


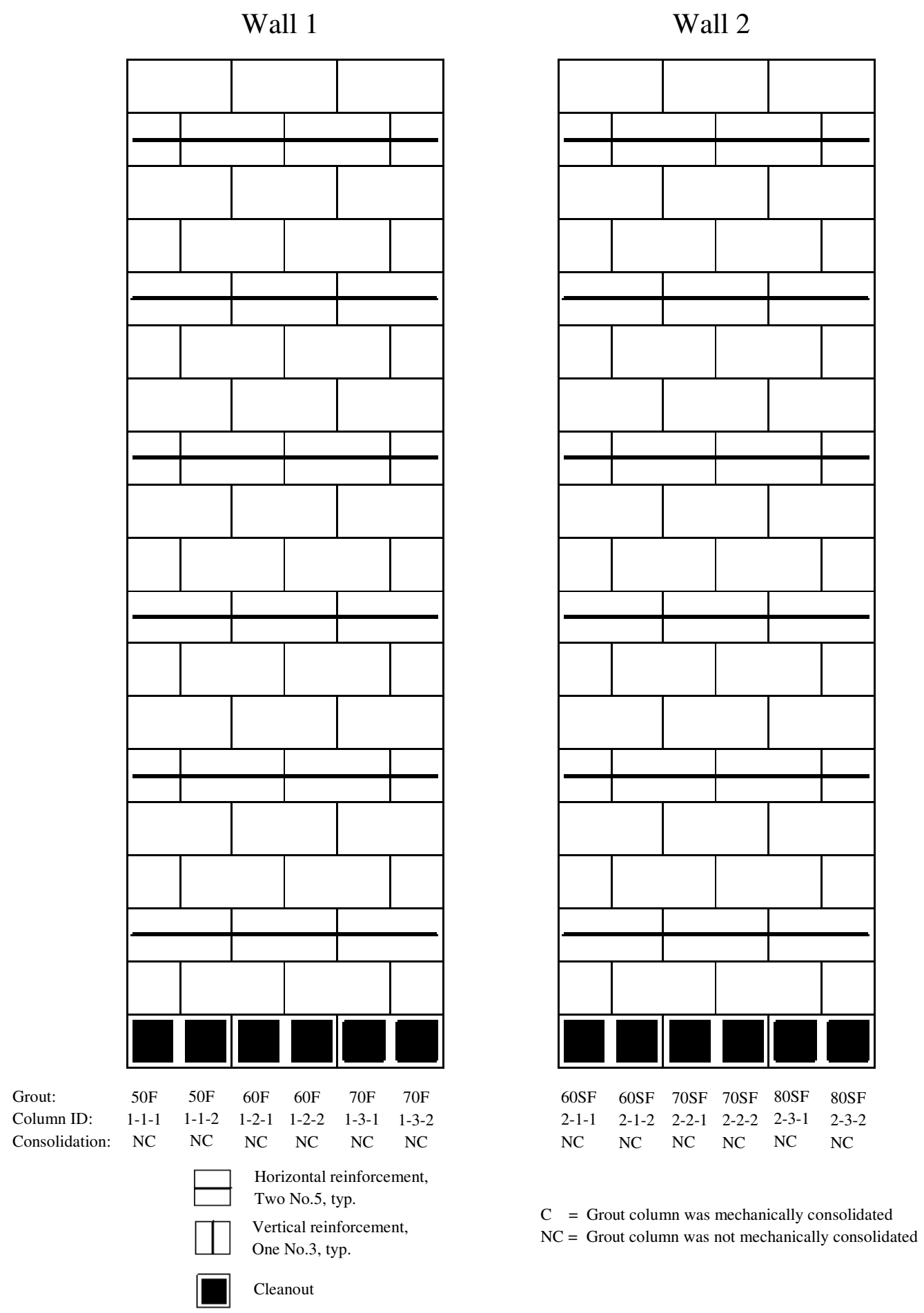

Figure J (1): Wall Configuration Elevations

Source: Author Diagrams

Performance of No Vibration/No Admixture Masonry Grout Containing High Replacement of Portland Cement with Fly Ash and Ground Granulated Blast Furnace Slag 

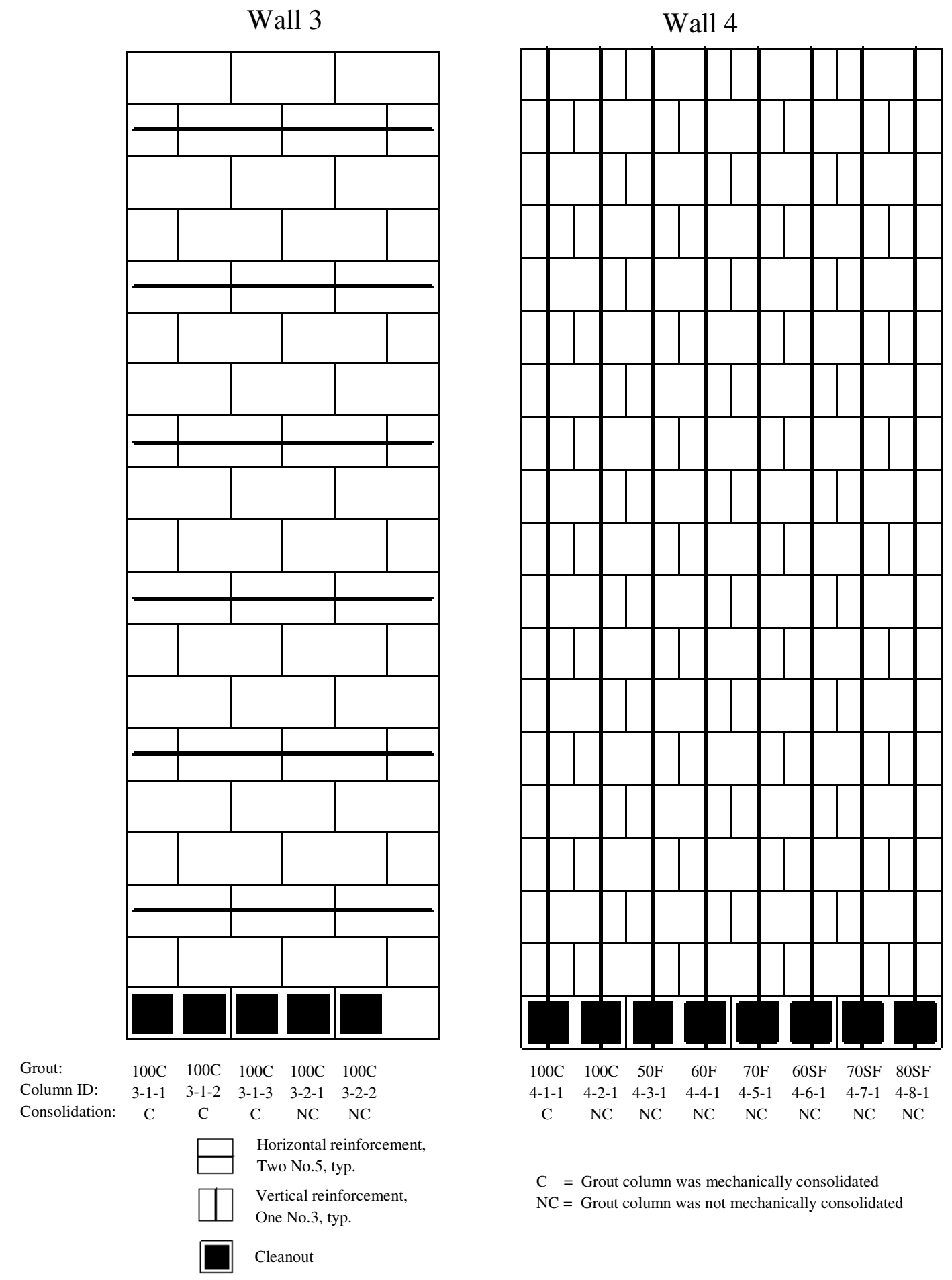

Figure J (2): Wall Configuration Elevations

Source: Author Diagrams

Performance of No Vibration/No Admixture Masonry Grout Containing High Replacement of Portland Cement with Fly Ash and Ground Granulated Blast Furnace Slag 


\subsubsection{Constructing the Walls}

The walls were constructed in an indoor facility, the High Bay Laboratory at California Polytechnic State University in San Luis Obispo, California. Before the first courses of CMUs were positioned, sections of cardboard matching the width and thickness of the walls were placed on the floor. The cardboard served as a membrane between the grout and floor, insuring that a bond between the two would not be made. This was important later in the procedure when the walls were tilted and lowered down in order to help ensure the walls did not crack. Following the design of the wall, the walls were erected by professional masons in one lift, as shown in Figure K.

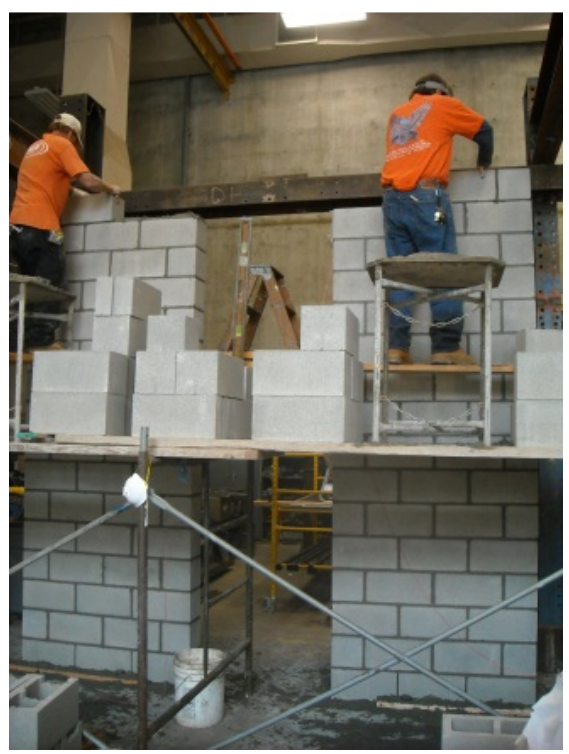

Figure K: Professional Masons Building Walls 1 and 2 Source: Author Photo

\subsubsection{Grouting the Walls}

The walls were grouted between 77 to 81 days on site after the walls were erected.

The materials were batched by volume and mixed in a mechanical mixer in accordance Performance of No Vibration/No Admixture Masonry Grout Containing High Replacement of Portland Cement with Fly Ash and Ground Granulated Blast Furnace Slag 
with ASTM C 476 as shown in Figure B. A slump test, following ASTM C 143, was conducted for the conventional grouts (shown in Appendix A.5) and a slump flow test, following ASTM C 1611, was conducted for the experimental grouts (shown in Appendix A.6). The grout was transported in five gallon buckets to the top of the walls where it was remixed by hand to ensure the aggregates did not settle during the transportation, as shown in Figure L(1). The grout was poured into the grout column through a funnel at the top, as shown in Figure L(2).
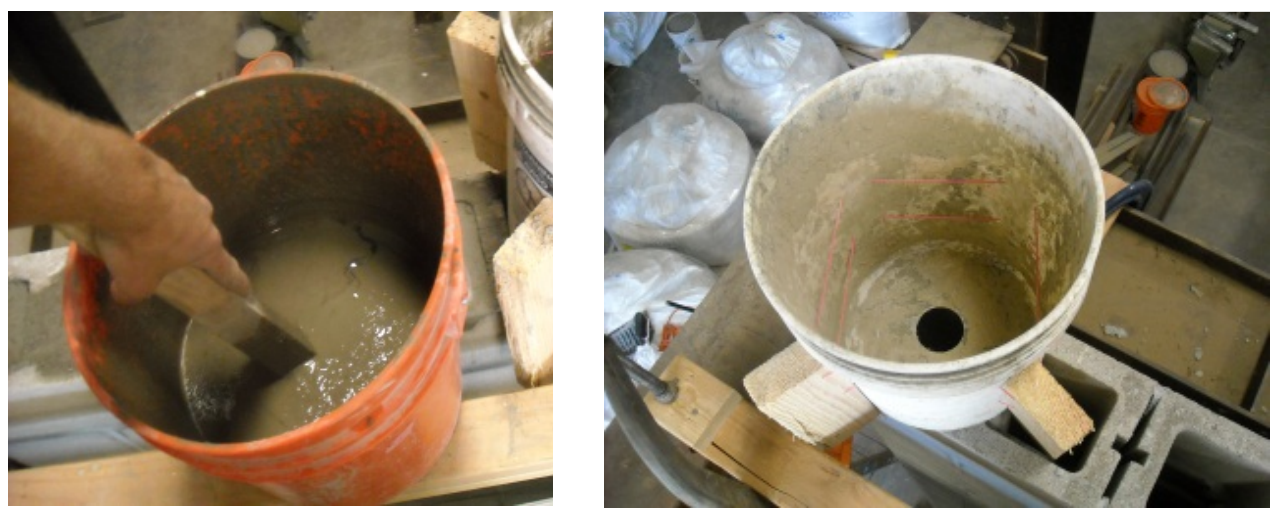

\section{Figure L: (1) Remixing Grout by hand and (2) Grout Funnel Leading into One} Grout Column Source: Author Photos

Each grout column took approximately 30 minutes to complete. A flashlight was used to check if there was any seepage of the grout into the adjacent grout columns. There was no noticeable seepage found for all groutings. For the conventional grout columns with mechanical consolidation, a $13 \mathrm{ft}$. long, 1 in. diameter, mechanical internal-type vibrator was lowered into the center of the cells and all the way to the bottom of the column before the grout was poured. After approximately one third of the 
grout column was poured, the vibrator was turned on, left for 5 seconds, and slowly lifted out one third of the way as shown in Figure M. This process was repeated two more times until the grout column was completely grouted and vibrated. The total time of vibration per grout column was approximately 30 seconds.

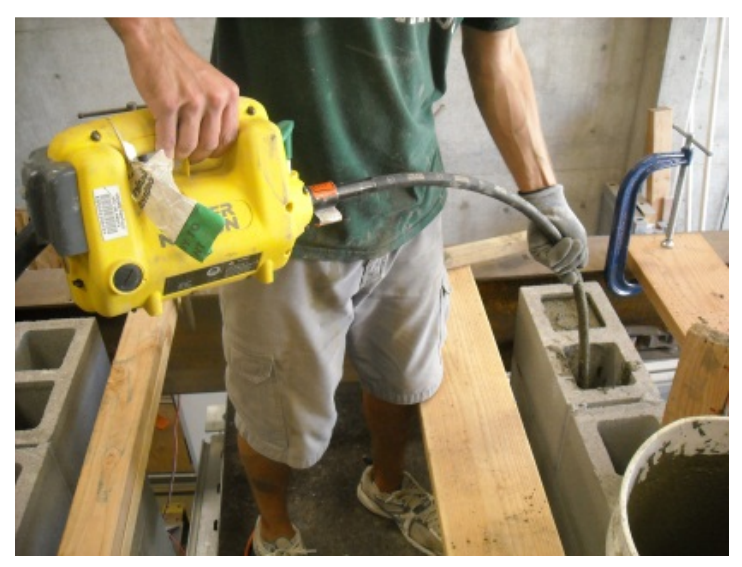

\section{Figure M: Mechanical Vibration}

Source: Author Photo

The conventional grout columns with mechanical consolidation were grouted and vibrated before the other grouts in the same walls were poured to ensure that the grouts did not receive any form of mechanical consolidation. Table 4 lists the grouting column order.

\section{Table 4: Grouting Schedule for Wall Experiment}

\begin{tabular}{|c|c|}
\hline \multicolumn{2}{|c|}{ Grouting Schedule } \\
\hline Date & Column Grouting Order Per Day \\
\hline $7 / 27 / 2012$ & $1-1-1,1-1-2,1-2-1,1-2-2,1-3-1,1-3-2$ \\
\hline $7 / 28 / 2012$ & $3-1-1,3-1-2,3-1-3,4-1-1,3-2-1,3-2-2,4-2-1$ \\
\hline $7 / 29 / 2012$ & $2-1-1,2-1-2,2-2-1,2-2-2,2-3-1,2-3-2$ \\
\hline $7 / 30 / 2012$ & $4-3-1,4-4-1,4-5-1,4-6-1,4-7-1,4-8-1$ \\
\hline
\end{tabular}

Performance of No Vibration/No Admixture Masonry Grout Containing High Replacement of Portland Cement with Fly Ash and Ground Granulated Blast Furnace Slag 


\subsubsection{Lowering the Walls}

The walls were lowered to a horizontal position approximately 70 days after being grouted. The walls were confined by lumber and straps, tilted using a forklift, and lowered using an overhead crane, as shown in Figure N.
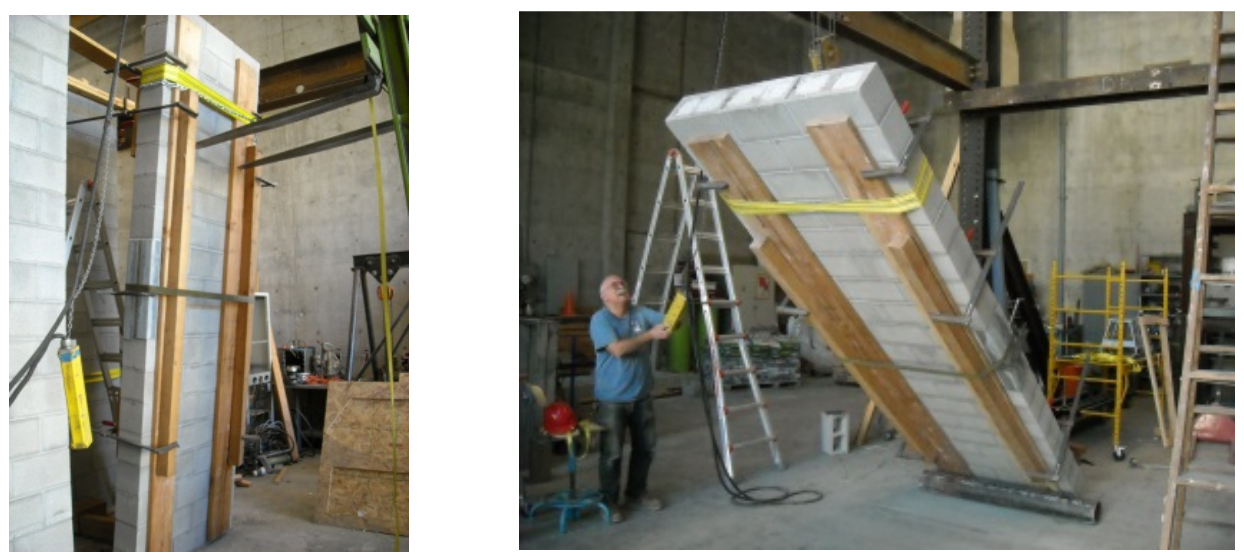

Figure N: (1) Fork Lift Tilting Wall and (2) Overhead Crane Lowering Wall Source: Author Photos

Once the wall was in a horizontal position, the forklift and overhead crane were used to transport the wall approximately $20 \mathrm{ft}$. outside of the laboratory, resting on empty CMUs, as shown in Figure O.

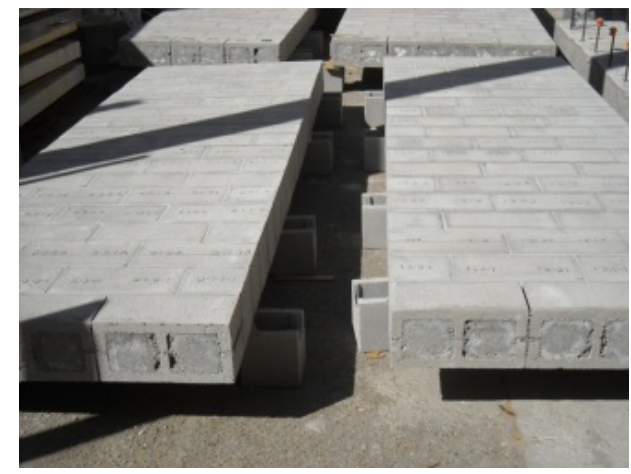

\section{Figure O: Walls Resting Horizontally}

Source: Author Photo

Performance of No Vibration/No Admixture Masonry Grout Containing High Replacement of Portland Cement with Fly Ash and Ground Granulated Blast Furnace Slag 


\subsubsection{Labeling the Walls}

For walls 1, 2, and 3, there were six different heights along the wall where both the wall compression specimens and reinforcement specimens were taken from each grout column. The location of each specimen was identified by a 3-digit grout column ID code, as shown in Figures $\mathrm{J}(1)$ and $\mathrm{J}(2)$, with an added marker at the end to indicate the height along the column where that specimen came from. For wall compression specimens, the last markers were numbers that varied from 1-6, 1 being the closest to the bottom of the wall and 6 being the closest to the top of the wall. The wall compression specimens were taken at heights of $12,36,60,84,108$, and 132 inches from the bottom of the wall. For the reinforcement specimens, the last markers were letters in alphabetical order from A-F, A, starting closest to the bottom of the wall and, F, nearest the top. The reinforcement specimens were taken at heights of 20,44, 68, 92, 116, and 140 inches from the bottom of the wall.

For Wall 4, there were three different heights along the wall where rebar pullout specimens were taken. The additional last digit was marked number 1 for specimens taken at 16 in., 2 for specimens taken at 64 in., and 3 for specimens taken at 128 in. from the bottom of the wall. Locations of the specimens from the walls are shown in Figures $\mathrm{P}(1)$ and $\mathrm{P}(2)$, on the following pages. 
Wall 1

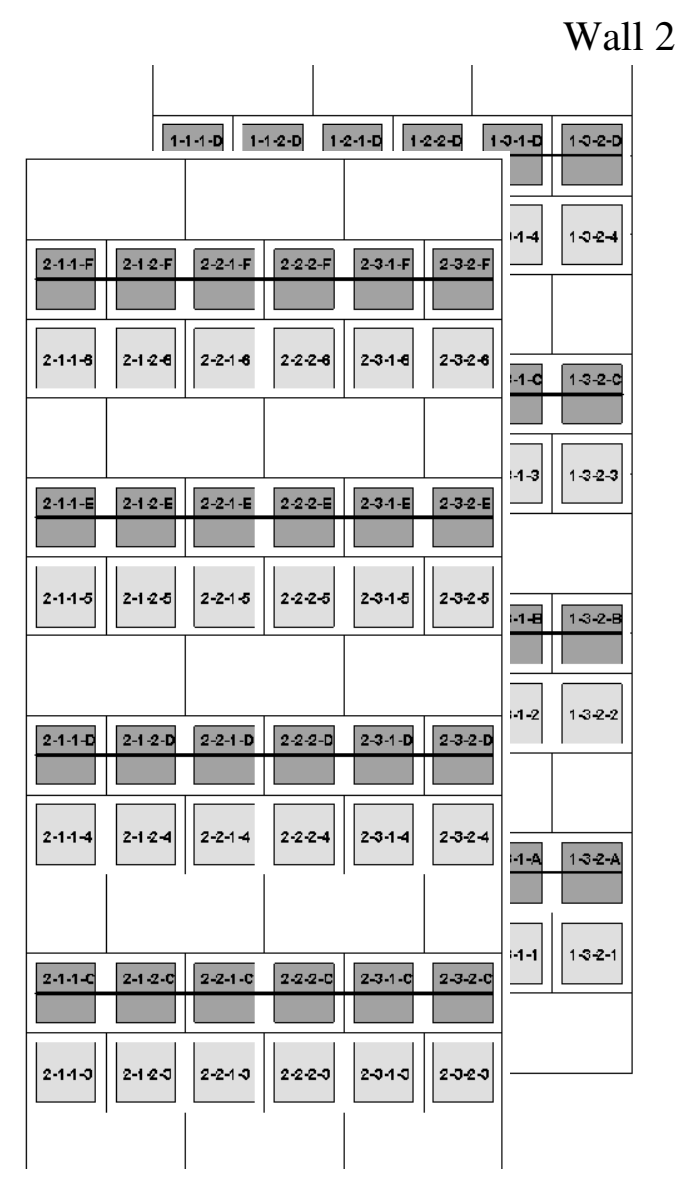

\footnotetext{
1-1-1-1 Wall Compression Specimen

Reinforcement Specimen
}

Figure P (1): Location of Specimens Source: Author Diagram

Wall 3

Wall 4

Performance of No Vibration/No Admixture Masonry Grout Containing High Replacement of Portland Cement with Fly Ash and Ground Granulated Blast Furnace Slag 


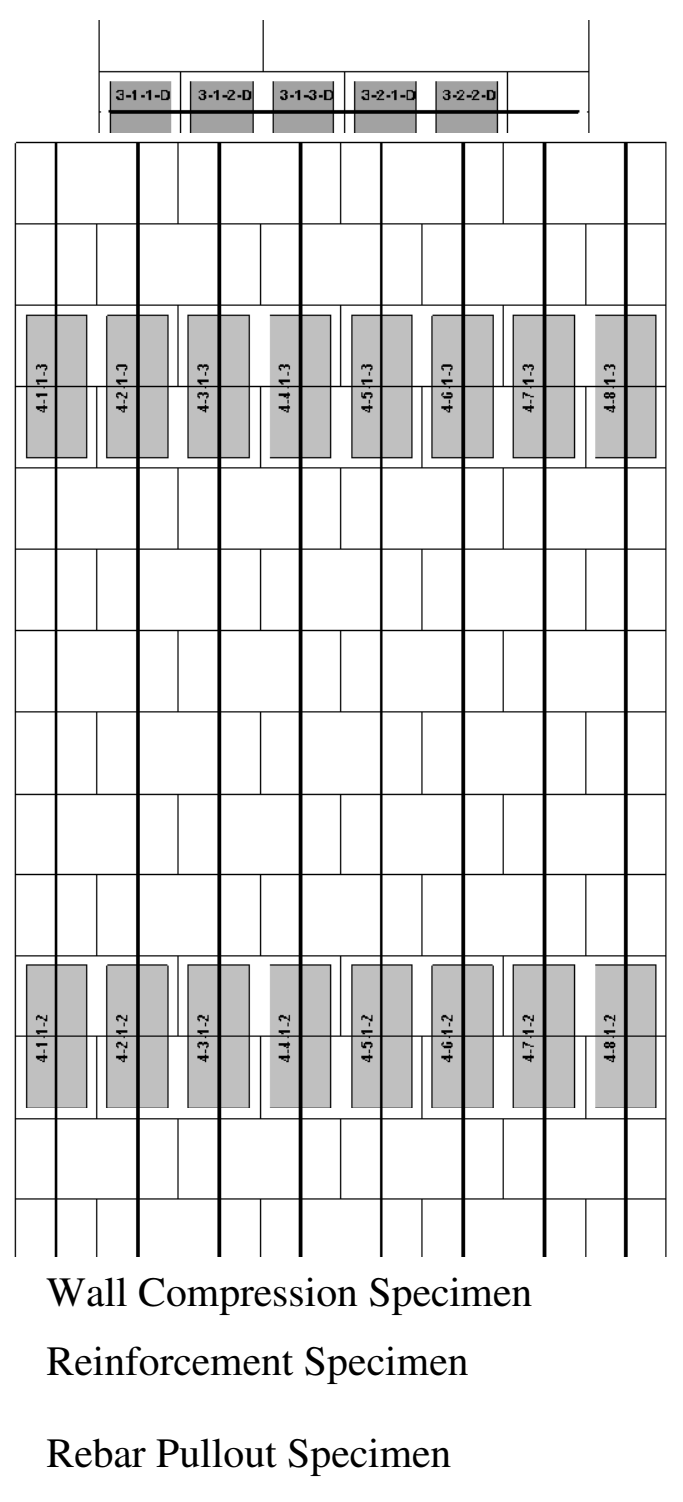

Figure P (2): Location of Specimens Source: Author Diagram

\subsubsection{Cutting the Walls}

The walls were cut by a demolition contractor using 16 and 18 in. diameter diamond bladed saws and a 14 in. diameter hydraulic ring saw in order to retrieve the test specimens. For walls 1, 2, and 3, a horizontal cut across each course was made, as shown 
in Figure Q(1). For wall 4, two horizontal cuts were made to split the wall into thirds and vertical cuts were made in-between each grout column, as shown in Figure $Q(2)$.
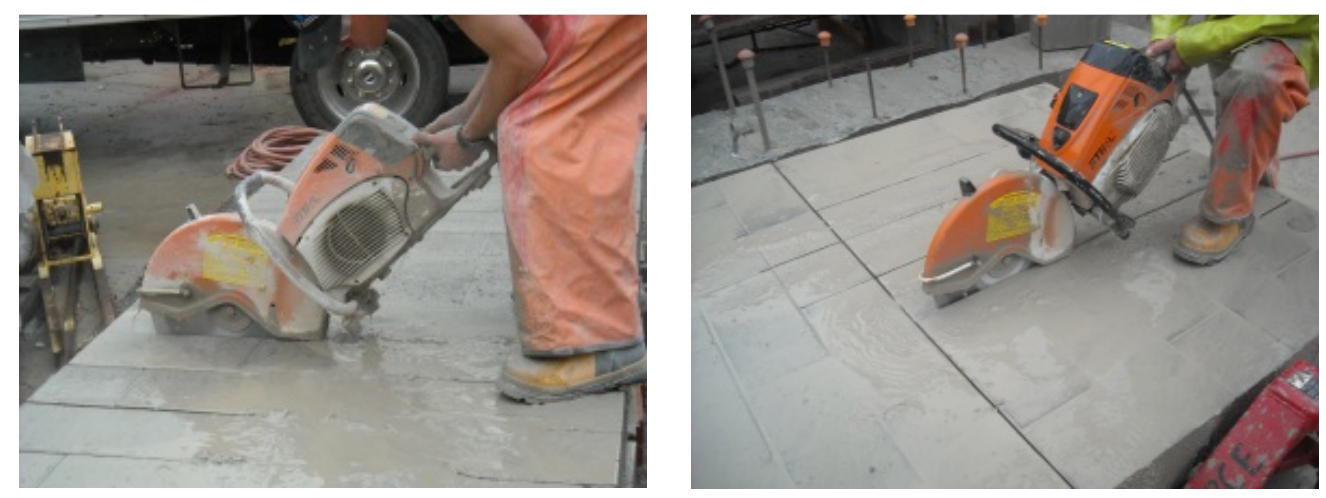

Figure Q: Cutting Walls: (1) Horizontally and (2) Vertically

Source: Author Photos

For walls 1, 2, and 3, a hand saw with a 14 in. diameter diamond blade was used to cut through the horizontal reinforcement at the mortar joints in order to separate each CMU, as shown in Figure R.

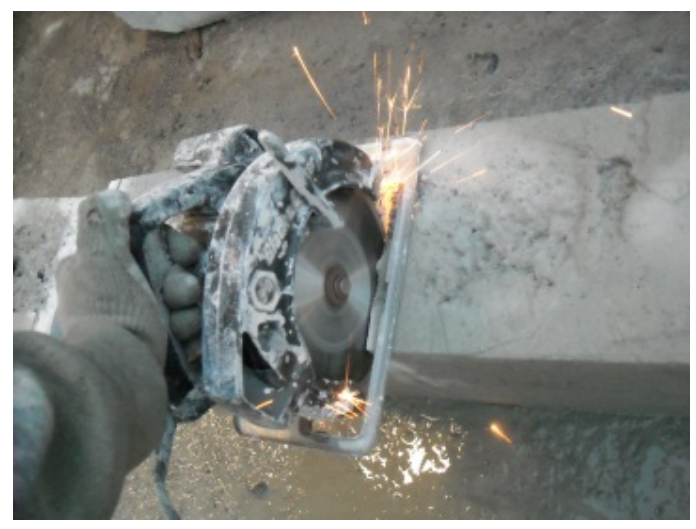

Figure R: Cutting through Reinforcement Using a Hand Saw Source: Author Photo

Performance of No Vibration/No Admixture Masonry Grout Containing High Replacement of Portland Cement with Fly Ash and Ground Granulated Blast Furnace Slag 
A 20 in. diamond blade wet saw was used to cut the wall compression specimens into 4x4x8 in. (nominal) grout units, as shown in Figure D, and the reinforcement specimens were cut once vertically across the middle of each grout cell containing reinforcement in order to see the consolidation characteristics adjacent to the reinforcement. In total, 96 wall compression test specimens and 96 reinforcement specimens were retrieved from the walls, as shown in Figure $S$.
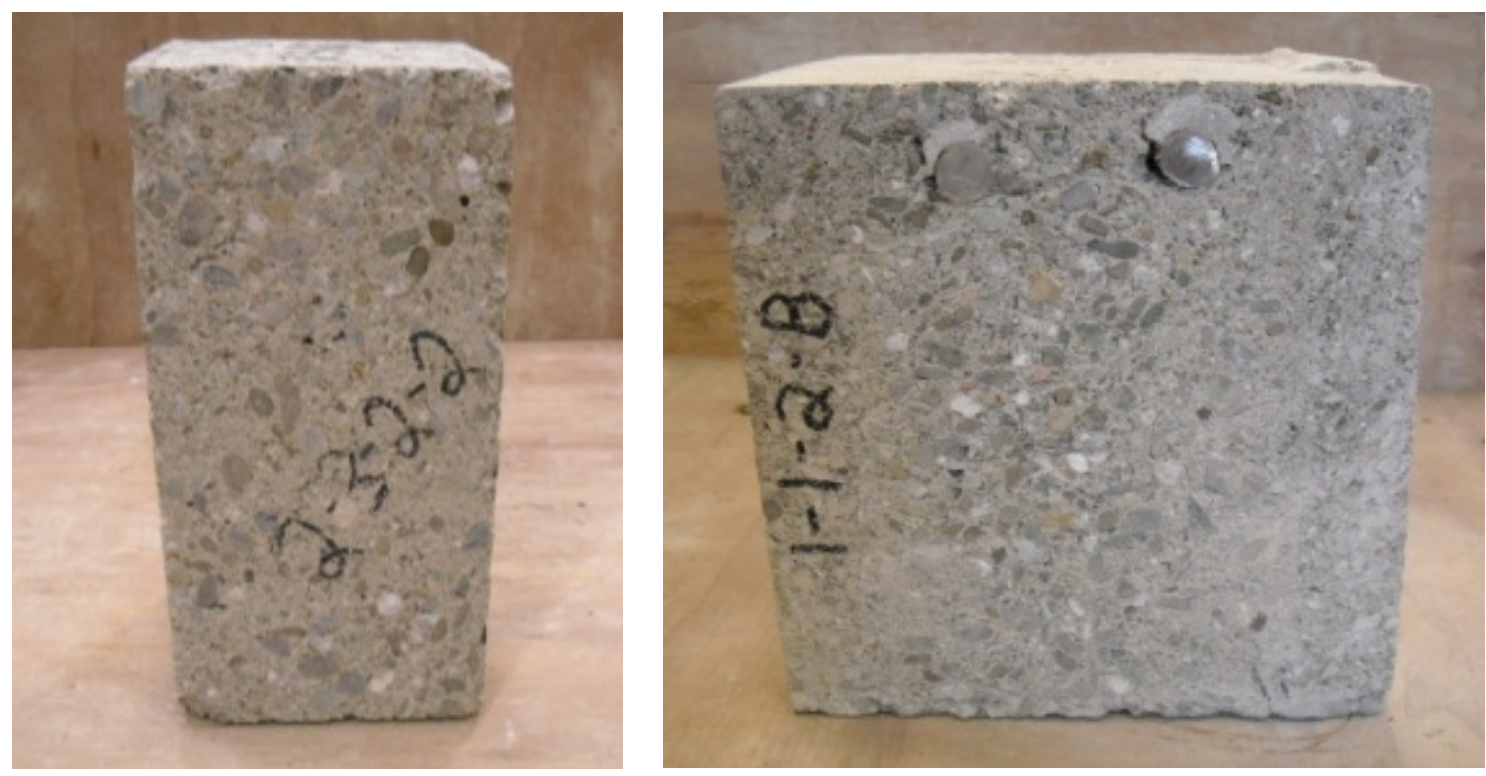

\section{Figure S: (1) Side View of Wall Compression Specimen and (2) Reinforcement Specimen}

Source: Author Photos

For wall 4, the unwanted grout in each rebar pullout section was chiseled away from the reinforcement using a jack hammer and a hand chisel in order to prepare specimens for rebar pullout test, as shown in Figure T. 

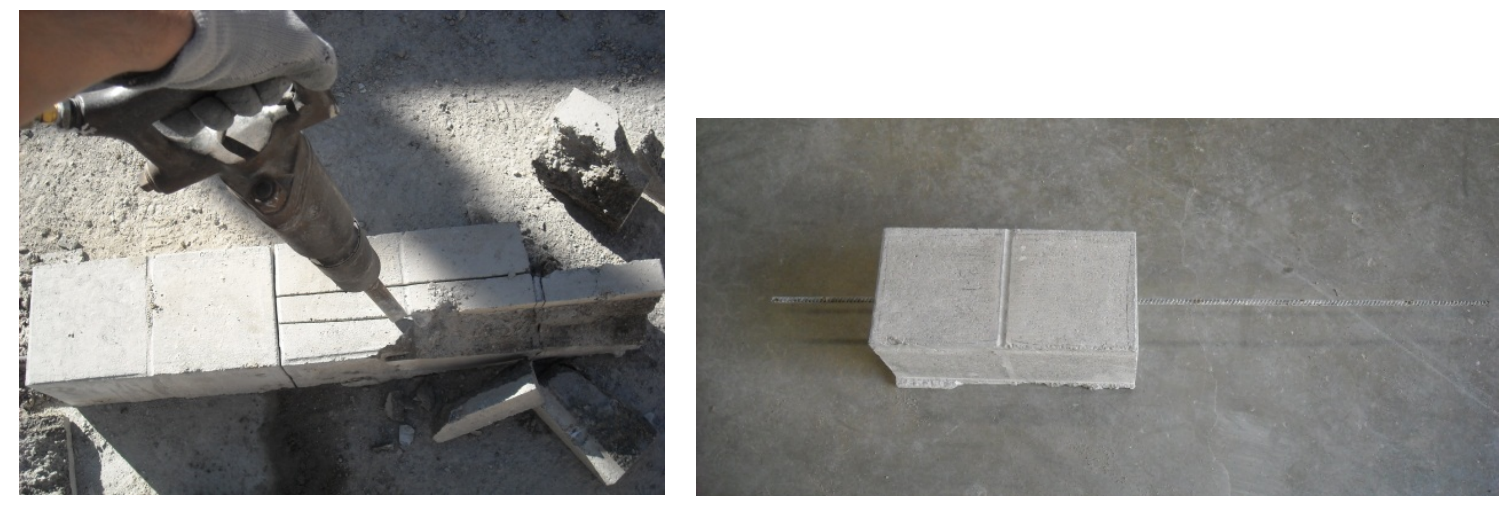

Figure T: (1) Chiseling Away Grout from Reinforcement and (2) Rebar Pullout Specimen

Source: Author Photos

\subsubsection{Testing of Specimens}

4.4.7.1 Wall Compression Tests. The retrieved wall compression specimens were capped and prepared for testing in accordance with ASTM C 1552, shown in Figure E(1).

The specimens were tested in compression, after 130 day of curing, in accordance with ASTM C 1019, as shown in Figure U.

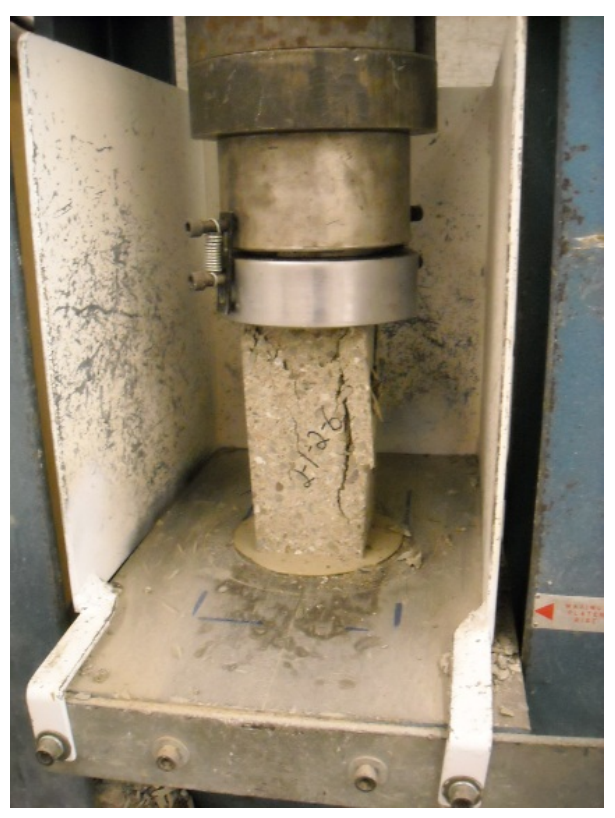

Performance of No Vibration/No Admixture Masonry Grout Containing High Replacement of Portland Cement with Fly Ash and Ground Granulated Blast Furnace Slag 


\section{Figure U: Compression Testing of Wall Compression Test Specimen 2-1-2-6}

Source: Author Photo

4.4.7.2 Wall Consolidation Inspection. The consolidation characteristics (segregation of aggregates and presence of air voids) were visually examined from the wall compression and reinforcement specimens. The sizes of air voids were recorded for (1) the top view (before final cutting) from the wall compression specimens (indicated consolidation around the mortar fins shown in Figure V), (2) the side view from the retrieved wall compression specimens (indicated consolidation on specimen's surface shown in Figure S(1)), and (3) the reinforcement specimens (revealed consolidation adjacent to the reinforcement shown in Figure $S(2)$ ).

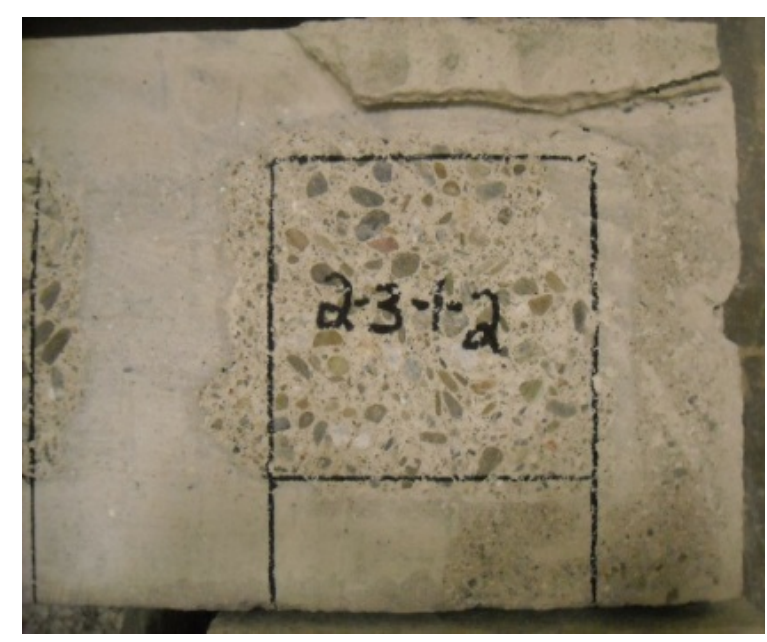

Figure V: Top View of Wall Compression Specimen

Source: Author Photo 
The reinforcement specimens were graded on an acceptance level modified from shotcrete core consolidation grades (ACI 560.2-95 1995), as shown in Table 5.

Table 5: Modified Shotcrete Core Consolidation Grades

\begin{tabular}{|c|c|c|c|c|c|}
\hline \multirow{2}{*}{ Location of voids } & \multicolumn{5}{|c|}{ Visually Inspected Diameter of Air Voids (Inches) } \\
\cline { 2 - 6 } & \multicolumn{5}{|c|}{ Grade } \\
\cline { 2 - 6 } & 1 & 2 & 3 & 4 & 5 \\
\hline General & $\leq 1 / 8$ & $\leq 3 / 8$ & $\leq 3 / 8$ & $\leq 3 / 8$ & $>3 / 8$ \\
\hline Near Reinforcement & None & $\leq 1 / 2$ & $\leq 5 / 8$ & $\leq 1$ & $>1$ \\
\hline
\end{tabular}

Shotcrete is concrete or mortar conveyed through a hose and pneumatically projected at high velocity onto a surface. Shotcrete is consolidated by material impact and quality control procedures must be established to assure that the final product function as designed (ACI 506.2-95 1995). The acceptance of consolidation quality is obtained from drilled cores containing reinforcement and visually inspected for compliance with the specified shotcrete core grades. Determination of grade is computed by taking the mean of a minimum of three test specimens. A mean grade of 2.5 or less is acceptable and individual shotcrete cores with a grade greater than 3 are unacceptable. 
4.4.7.3 Rebar Pullout Tests. The rebar pullout specimens were tested at approximately 170 days of curing in accordance with ASTM C 900 Standard Test Method for Pullout Strength of Hardened Concrete, as shown in Figure W.

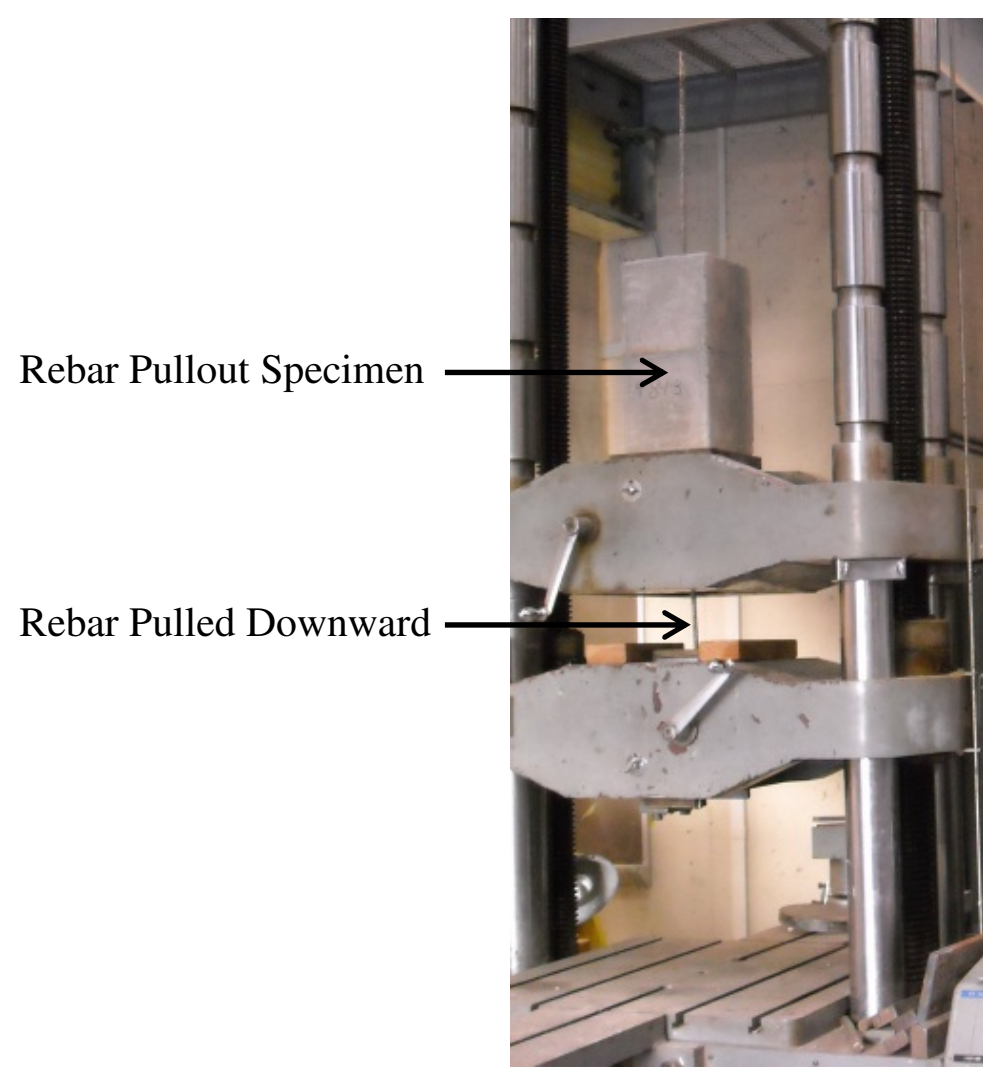

Figure W: Rebar Pullout Test

Source: Author Photo

Performance of No Vibration/No Admixture Masonry Grout Containing High Replacement of Portland Cement with Fly Ash and Ground Granulated Blast Furnace Slag 


\subsection{RESULTS}

\subsection{Slump/Slump Flow}

The conventional grout was determined to have a water-to-cement ratio of 1.375 (by volume), which provided an average slump of 9.75 inches (presented in Appendix A.1), following ASTM C 143.

The experimental grouts were found to have a slump flow between 24 to 30 inches for all mixtures, following ASTM C 1611; therefore, satisfying one of the requirements to be considered a self-consolidating grout according to ASTM C 476. For both types of cement replacement (fly ash and fly ash/GGBFS), it was found that, in general, the slump flow increased in diameter as the amount of cement in the mixture decreased, as shown in Figure X.

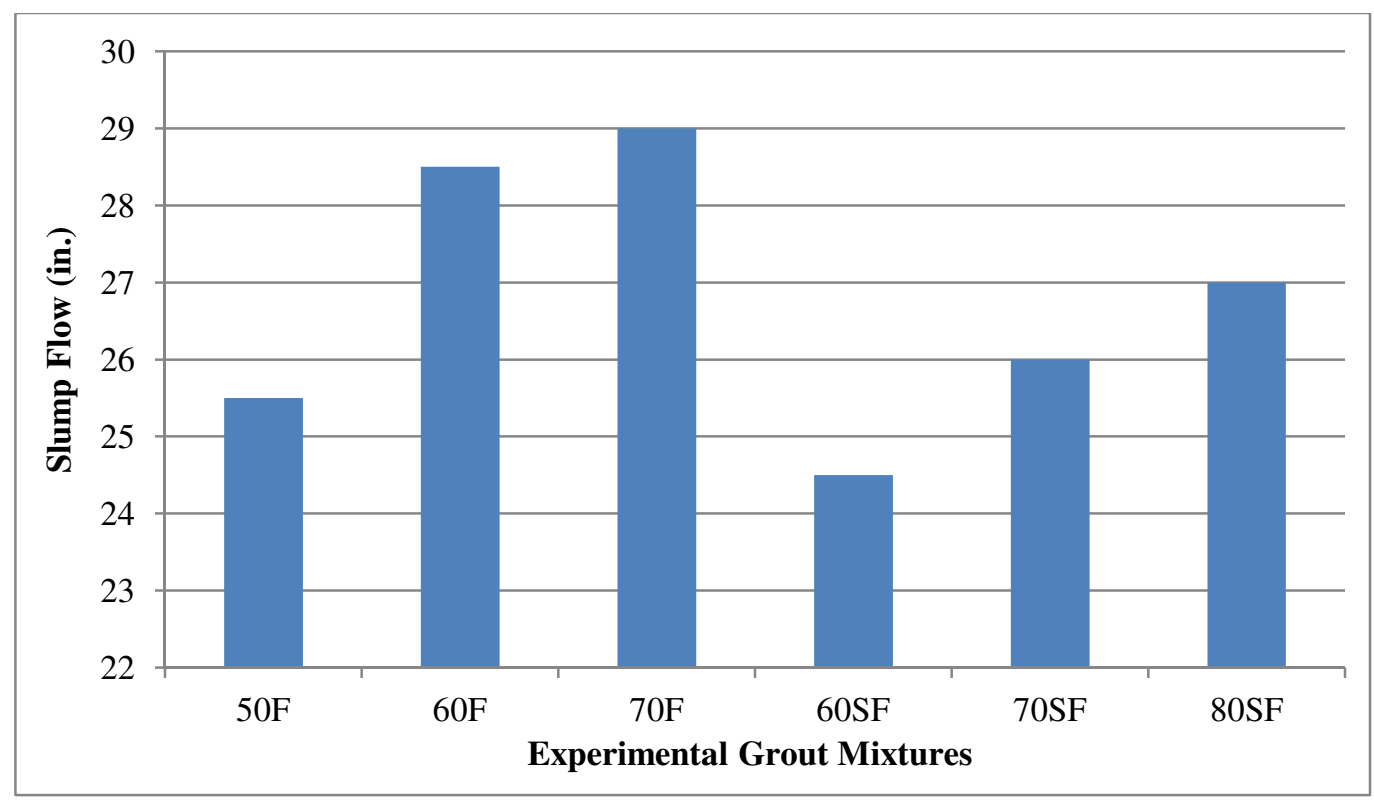

Figure X: Average Slump Flows of Experimental Grouts

Source: Author Figure

Performance of No Vibration/No Admixture Masonry Grout Containing High Replacement of Portland Cement with Fly Ash and Ground Granulated Blast Furnace Slag 
All experimental grouts were found to have a VSI of 1 (Stable) as there was no evidence of segregation but a slight bleeding was observed as a sheen on the grout mass. None of the mixtures were considered unstable because there was no noticeable mortar halo and/or aggregate pile in the center of the grout mass. The slump flow results are presented in Appendix A.2, and an example photograph of the slump flow is shown in Figure Y. Providing a VSI of 1 satisfied another requirement of ASTM C476 for the experimental grouts to be considered self-consolidating grouts.

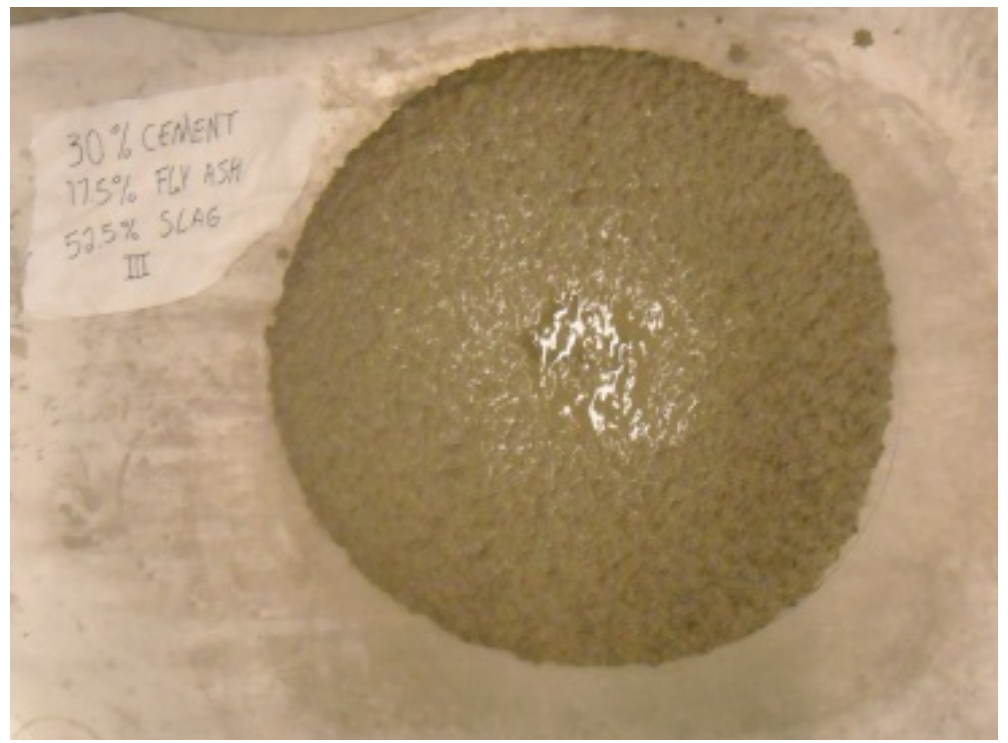

Figure Y: Slump Flow Picture of 70SF Batch 3

Source: Author Photo

\subsection{The Compression Experiment}

For each of the seven grout mixtures (100C, 50F, 60F, 70F, 60SF, 70SF, 80SF), three specimens were tested in compression at each curing time $(7,14,28,42,56$, and 130 days) in accordance with the applicable requirements of ASTM C 1019. A net compressive strength was determined for each specimen. From the net compressive 
strength of each specimen, a corrected net compressive strength was determined by multiplying by a correction factor based on the height-to-thickness ratio of the specimen, from Table 1 of ASTM C 1314 Standard Test Method for Compressive Strength of Masonry Prisms, in order to better account for the load carrying capacity. The corrected net compressive strengths for each group of three specimens were averaged and are presented in Appendix B. These averaged corrected net compressive strengths are shown in Figure Z.

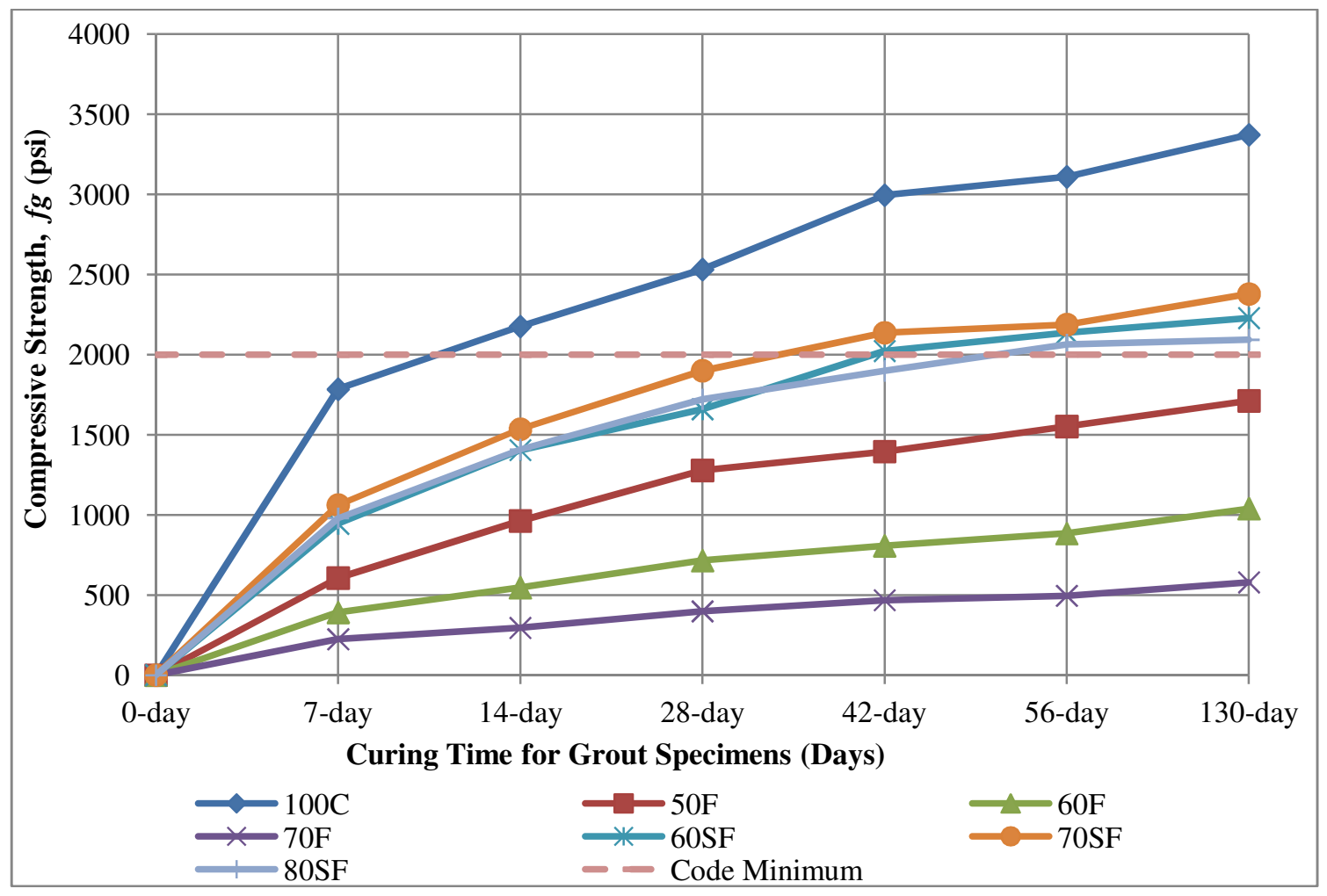

Figure Z: Average Corrected Net Compressive Strength of Grouts from the Compression Experiment

Source: Author Figure 
The tested grout compressive strengths are compared to the minimum requirements of the International Building Code (IBC 2012) and ASTM C 476, in order to determine their feasibility. The minimum requirements, call for the grout to have a compressive strength of at least 2,000 psi after 28 days of curing. Figure $\mathrm{Z}$ illustrates that only the convention grout, $100 \mathrm{C}$, met this requirement. By the tested cure time of 56 days, grout mixtures $60 \mathrm{SF}, 70 \mathrm{SF}$, and $80 \mathrm{SF}$ passed the 2,000 psi minimum. Grout mixtures $50 \mathrm{~F}, 60 \mathrm{~F}$, and $70 \mathrm{~F}$ did not meet this requirement through the tested cure time of 130 days.

\subsection{Wall Experiment}

\subsubsection{Wall Compression Tests}

Grout compression specimens cut from various heights along walls 1, 2, and 3 were tested in accordance of ASTM C 1019. Corrected net compressive strengths were determined and are presented in Appendix C. The curing time of these specimens were 130 days, matching the longest tested curing time of the compression specimens from the Compression Experiment. The wall compression test specimens were normalized by the average compressive strength results from the Compression Experiment at the curing time of 130 days, as provided in Appendix D. The normalized data demonstrates the similarity of compressive strengths achieved between The Wall Experiment and The Compression Experiment.

The compression test results from Wall 1 of the Wall Experiment specimens are shown in Figure AA, on the next page (data provided in Appendix C). 


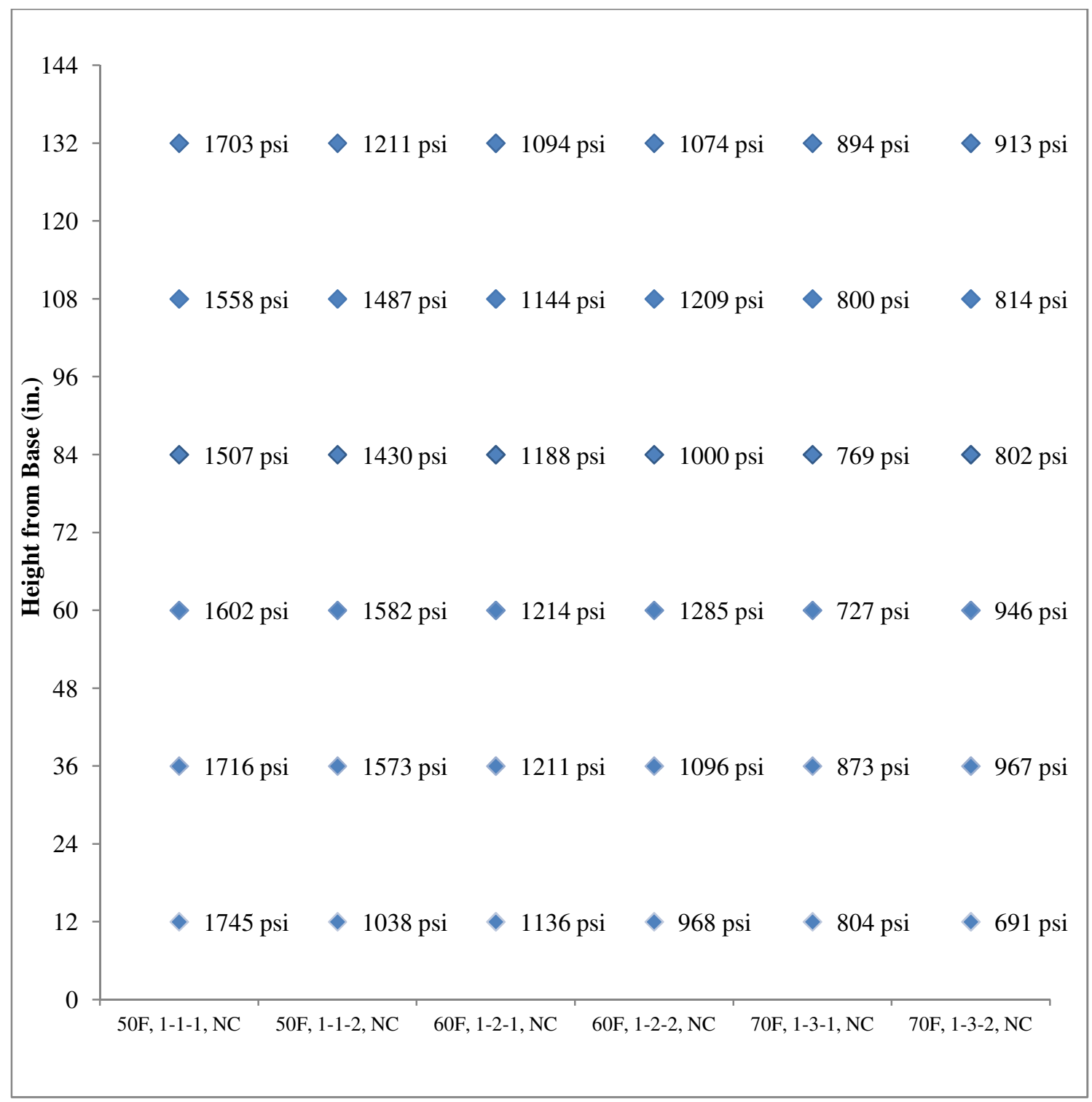

Figure AA: Wall 1 Grout Specimen's Corrected Net Compressive Strength Test Results

Source: Author Figure

Performance of No Vibration/No Admixture Masonry Grout Containing High Replacement of Portland Cement with Fly Ash and Ground Granulated Blast Furnace Slag 
The compression test results from Wall 2 of the Wall Experiment specimens are shown in Figure BB (data provided in Appendix C).

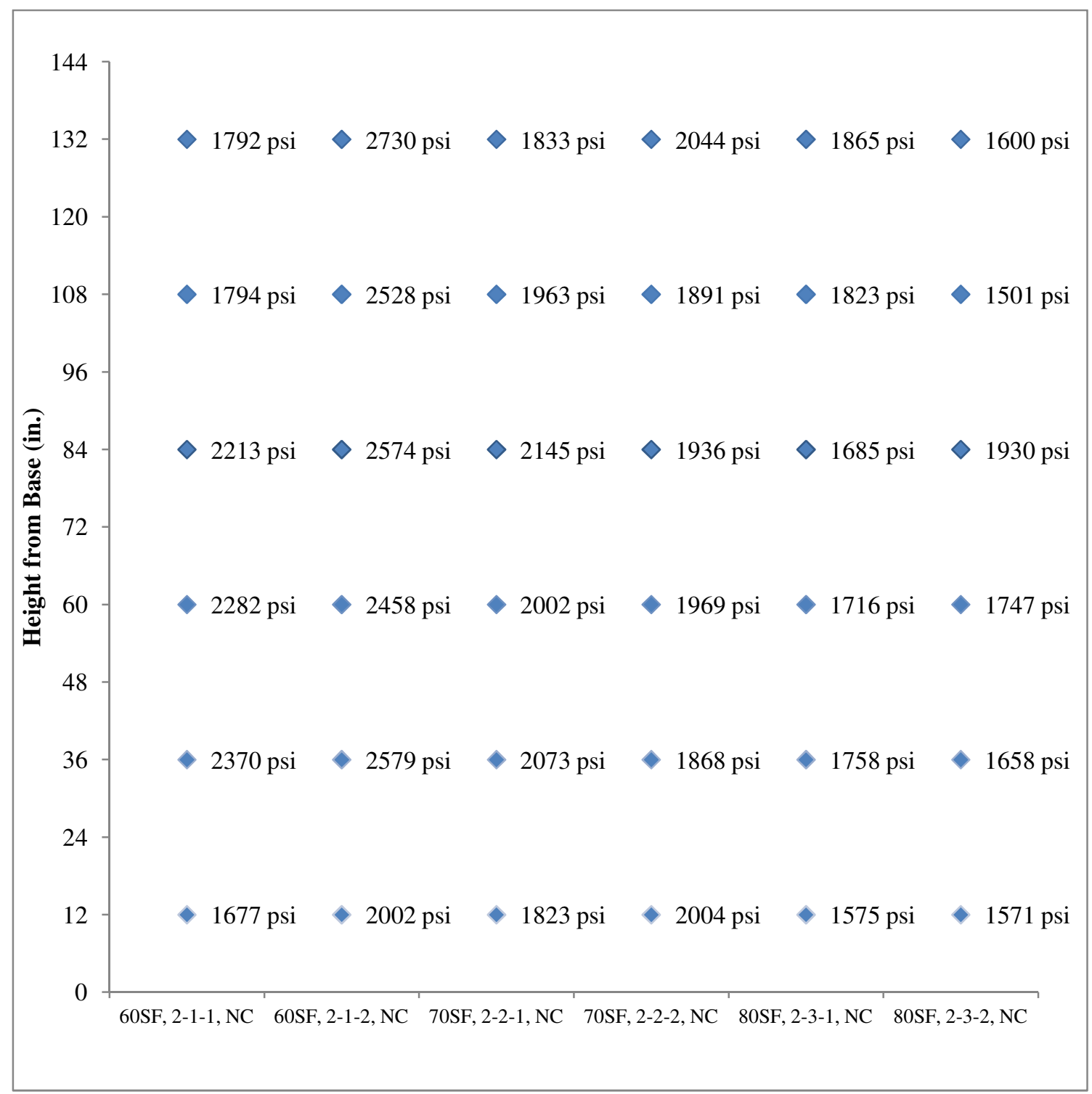

Figure BB: Wall 2 Grout Specimen's Corrected Net Compressive Strength Test Results

Source: Author Figure

Performance of No Vibration/No Admixture Masonry Grout Containing High Replacement of Portland Cement with Fly Ash and Ground Granulated Blast Furnace Slag 
The compression test results from Wall 3 of the Wall Experiment specimens are shown in Figure CC (data provided in Appendix C).

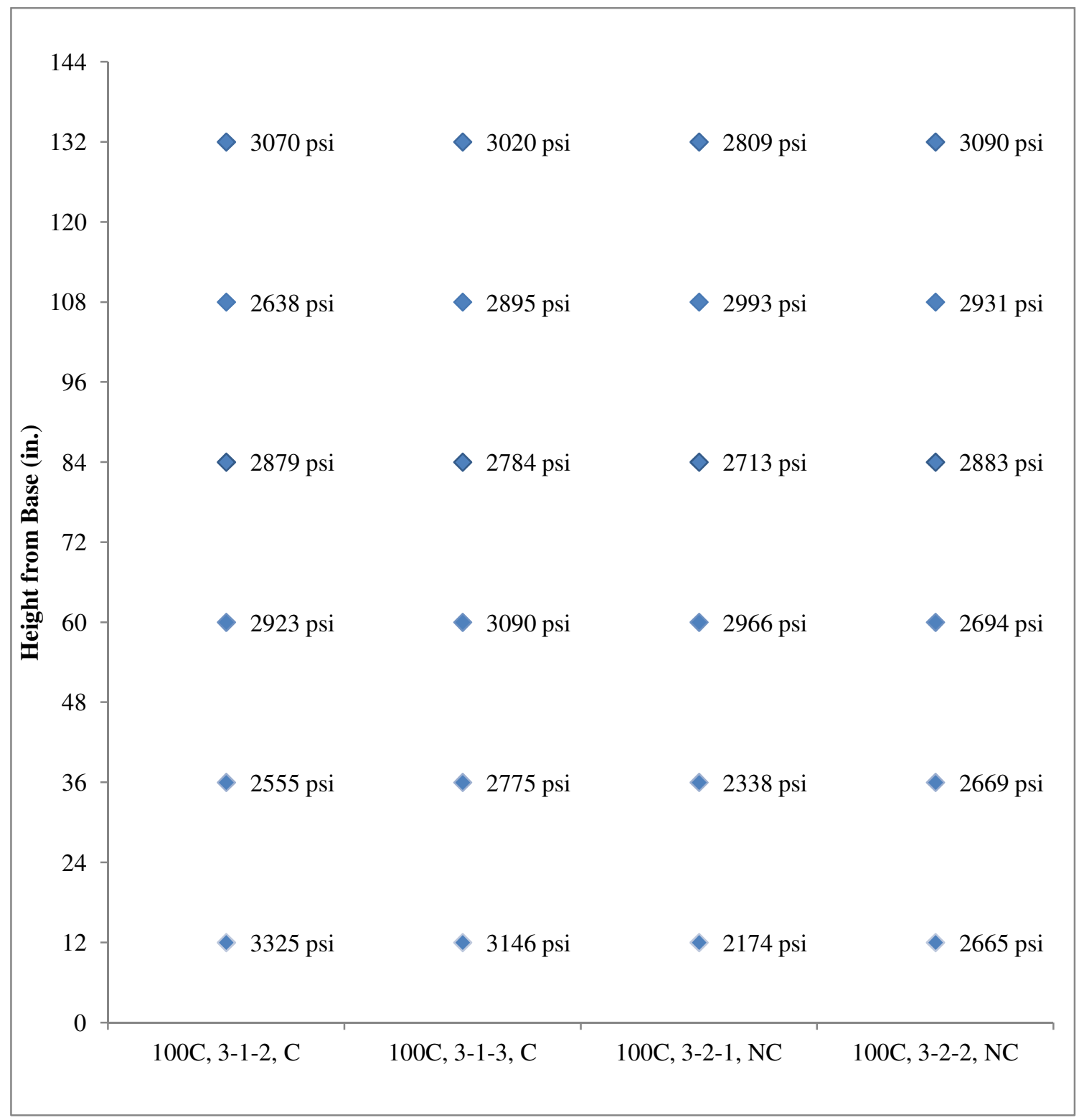

Figure CC: Wall 3 Grout Specimen's Corrected Net Compressive Strength Test Results

Source: Author Figure

Performance of No Vibration/No Admixture Masonry Grout Containing High Replacement of Portland Cement with Fly Ash and Ground Granulated Blast Furnace Slag 
The compressive strength results for the grout specimens with identical data sets combined (averaged compressive strength of specimens with the same grout type and at the same height along the wall), are shown in Figure DD (data found in Appendix D).

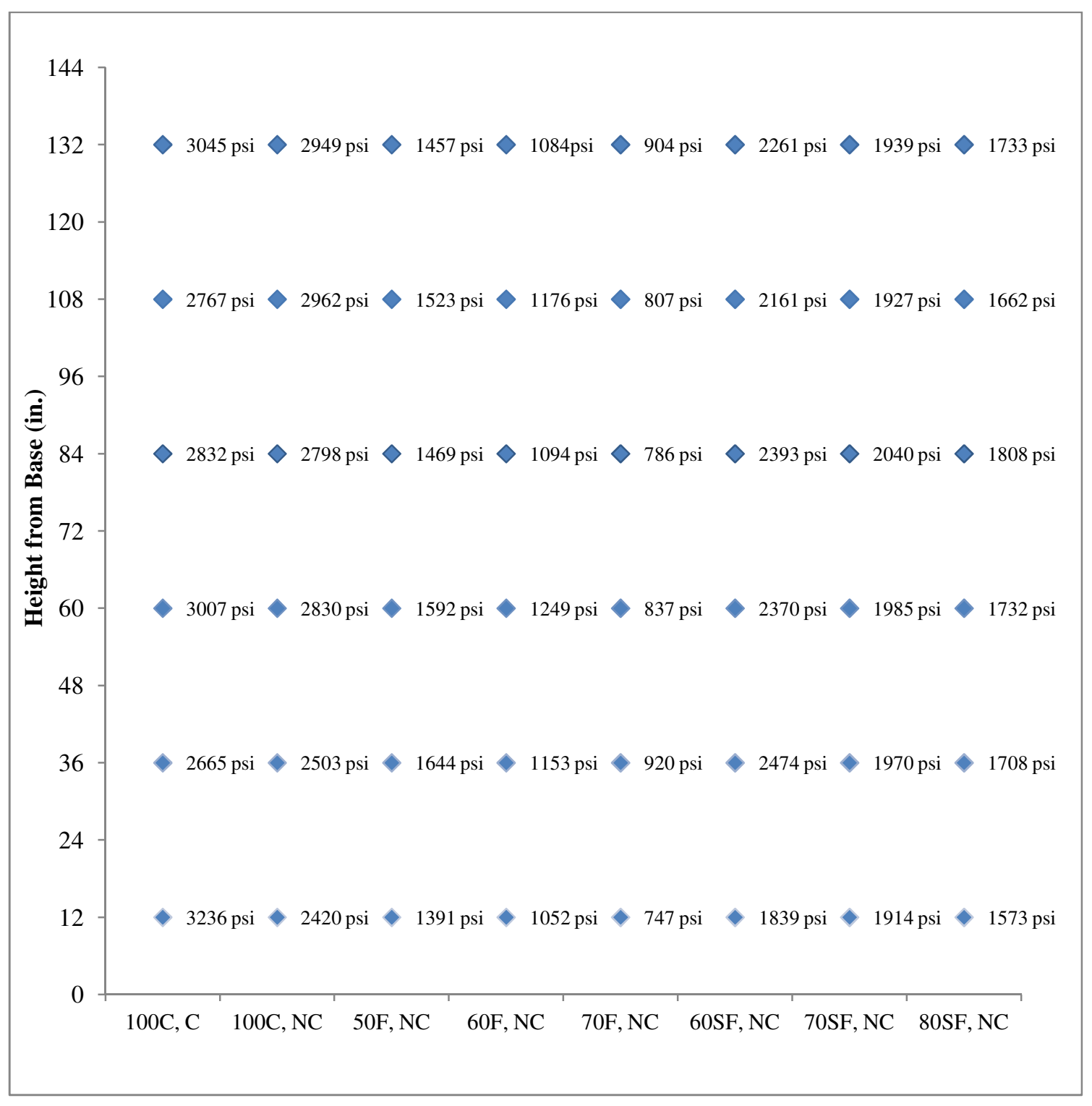

Figure DD: Compressive Strength Test Results of the Identical Data Sets Combined Source: Author Figure

Performance of No Vibration/No Admixture Masonry Grout Containing High Replacement of Portland Cement with Fly Ash and Ground Granulated Blast Furnace Slag 
The average corrected net compressive strengths of each grout mixture (over the entire wall height) are shown in Figure EE (data found in Appendix D).

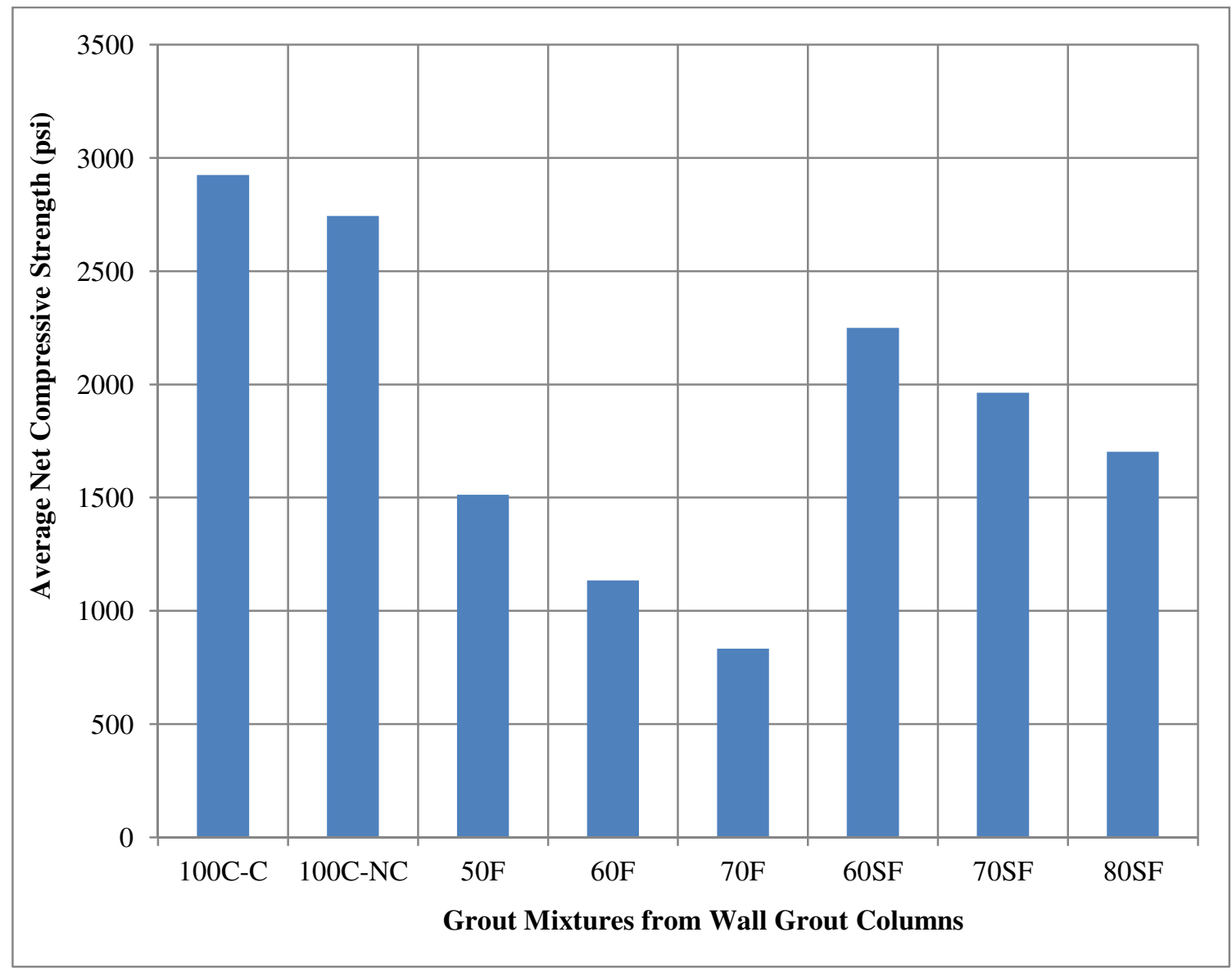

Figure EE: Average Corrected Net Compressive Strengths of Grout Mixtures along the Entire Height of the Wall from the Wall Experiment after 130 Days of Curing Source: Author Figure

Performance of No Vibration/No Admixture Masonry Grout Containing High Replacement of Portland Cement with Fly Ash and Ground Granulated Blast Furnace Slag 


\subsubsection{Effect of Mechanical Consolidation on Compressive Strength of}

Conventional Grout. The compressive strengths from wall 3 provide a direct comparison of mechanical consolidation (100C-C) to no mechanical consolidation (100C-NC) for conventional grout. The data summarized in Table 6 indicates that the differences between the consolidated and nonconsolidated compressive strengths are not significant. The overall average of all compressive strengths for the conventional grout nonconsolidated was a $6 \%$ decrease in compressive strength from the conventional grout consolidated.

Table 6: Difference in Conventional Grout Compressive Strength Due to Mechanical Consolidation

\begin{tabular}{|c|c|c|c|}
\hline $\begin{array}{c}\text { Height } \\
\text { from } \\
\text { Base } \\
\text { (in.) }\end{array}$ & $\begin{array}{c}\text { Average Corrected } \\
\text { Net Compressive } \\
\text { Strength of } \\
100 \mathrm{C}-\mathrm{C}(\mathrm{psi})\end{array}$ & $\begin{array}{c}\text { Average Corrected } \\
\text { Net Compressive } \\
\text { Strength of } \\
\text { 100C-NC }(\mathrm{psi})\end{array}$ & $\begin{array}{c}\text { NC \% } \\
\text { increase or } \\
\text { decrease } \\
\text { over C }\end{array}$ \\
\hline 132 & 3045 & 2949 & $-3 \%$ \\
\hline 108 & 2767 & 2962 & $7 \%$ \\
\hline 84 & 2832 & 2798 & $-1 \%$ \\
\hline 60 & 3007 & 2830 & $-6 \%$ \\
\hline 36 & 2665 & 2503 & $-6 \%$ \\
\hline 12 & 3236 & 2420 & $-25 \%$ \\
\hline
\end{tabular}

Performance of No Vibration/No Admixture Masonry Grout Containing High Replacement of Portland Cement with Fly Ash and Ground Granulated Blast Furnace Slag 


\subsubsection{Comparing the Corrected Net Compressive Strengths of the Wall}

Experiment and the Compression Experiment. The average net corrected

compressive strength from each mixture in the Wall Experiment is compared to the average net corrected compressive strength from the Compression Experiment. Both experiments are compared on compressive strength tests from 130 days of curing. The data in Table 7 indicates there is a moderate correlation between the two experiments.

Table 7: Difference in Net Corrected Compressive Strength of the Wall Experiment and Compression Experiment after 130 Days of Curing

\begin{tabular}{|c|c|c|c|}
\hline $\begin{array}{c}\text { Grout } \\
\text { Mixture }\end{array}$ & $\begin{array}{c}\text { Average Corrected Net } \\
\text { Compressive Strength } \\
\text { of Wall Experiment } \\
\text { (psi) }\end{array}$ & $\begin{array}{c}\text { Average Corrected Net } \\
\text { Compressive Strength } \\
\text { of Compression } \\
\text { Experiment (psi) }\end{array}$ & $\begin{array}{c}\text { \% increase or } \\
\text { decrease of Wall } \\
\text { Experiment over } \\
\text { Compression } \\
\text { Experiment }\end{array}$ \\
\hline $100 \mathrm{C}-\mathrm{C}$ & 2925 & 3372 & $-13 \%$ \\
\hline $100 \mathrm{C}-\mathrm{NC}$ & 2744 & 3372 & $-19 \%$ \\
\hline $50 \mathrm{~F}$ & 1513 & 1712 & $-12 \%$ \\
\hline $60 \mathrm{~F}$ & 1135 & 1039 & $9 \%$ \\
\hline $70 \mathrm{~F}$ & 833 & 579 & $44 \%$ \\
\hline $60 \mathrm{SF}$ & 2250 & 2228 & $1 \%$ \\
\hline $70 \mathrm{SF}$ & 1963 & 2379 & $-17 \%$ \\
\hline $80 \mathrm{SF}$ & 1702 & 2093 & $-19 \%$ \\
\hline
\end{tabular}

Performance of No Vibration/No Admixture Masonry Grout Containing High Replacement of Portland Cement with Fly Ash and Ground Granulated Blast Furnace Slag 


\subsubsection{Comparing Compressive Strengths with Visual Examination of Air Voids on}

Specimens. The top and side profiles of the compression specimens were visually examined and their air voids were measured, as shown in Appendix E. For all specimens and their profiles, no segregation of aggregates were noticed. Since the air voids were only examined on the surface of the compression specimens, the interior air voids of the specimens were unknown. Also, from the top profile, air voids around the mortar fins were recorded. Since the compression specimens were cut from the center of the grout columns, the imperfections around the mortar fins were not a part of the compression tests and had no influence on the tested compressive strengths.

Some of the compression specimens taken from the same mixture and height, but differing grout columns, had similar size air voids on the surface but their compressive strength would vary significantly. This indicates that the lower compressive strength specimens may have had larger air voids in their interior than exterior.

\subsubsection{Consolidation Characteristics}

The consolidation characteristics (segregation of aggregates and presence of air voids) were visually examined from cuts made throughout each grout column. The consolidation characteristics from the wall compression specimens are provided in Appendix E, and the consolidation characteristics and grades from the reinforcement specimens are provided in Appendix F.

All specimens showed no sign of segregation of aggregates and there was not a significant change in the size of air voids along the height of each grout column. 
From inspection of the wall compression specimens, all grouts were noticed to have an average of $1 / 16$ to $1 / 8$ inch diameter air voids located along the sides sections and next to the mortar fins of the top sections. There were two experimental specimens that had air voids greater than 3/8 inch in diameter and would qualify as Grade 5 or unacceptable according to the modified shotcrete consolidation grades in Table 5.

Each reinforcement specimen was graded on an acceptance level from Table 5. The average grades for each mixture are presented in Figure FF.

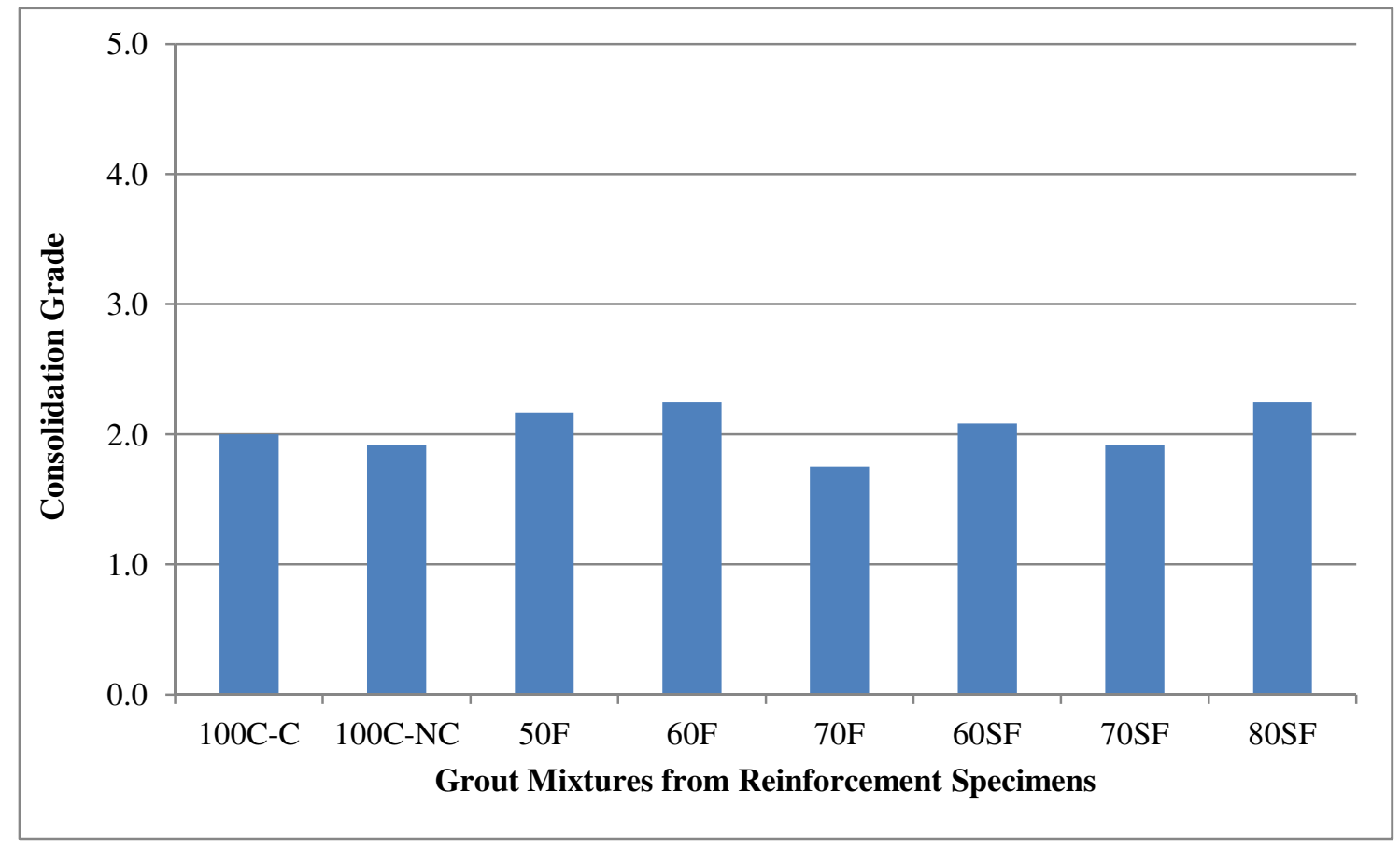

Figure FF: Average Consolidation Grade for Each Grout Mixture Source: Author Figure

The mean consolidation grades for all grouts were less than 2.5 , indicating that the consolidations were acceptable. There were five out of 96 total reinforcement 
specimens that were not acceptable; three specimens (60SF and two 80SF) were Grade 4, and two specimens (50SF and 60SF) were Grade 5.

Examples from the specimens visually inspected are shown in Figures GG, HH, and II.

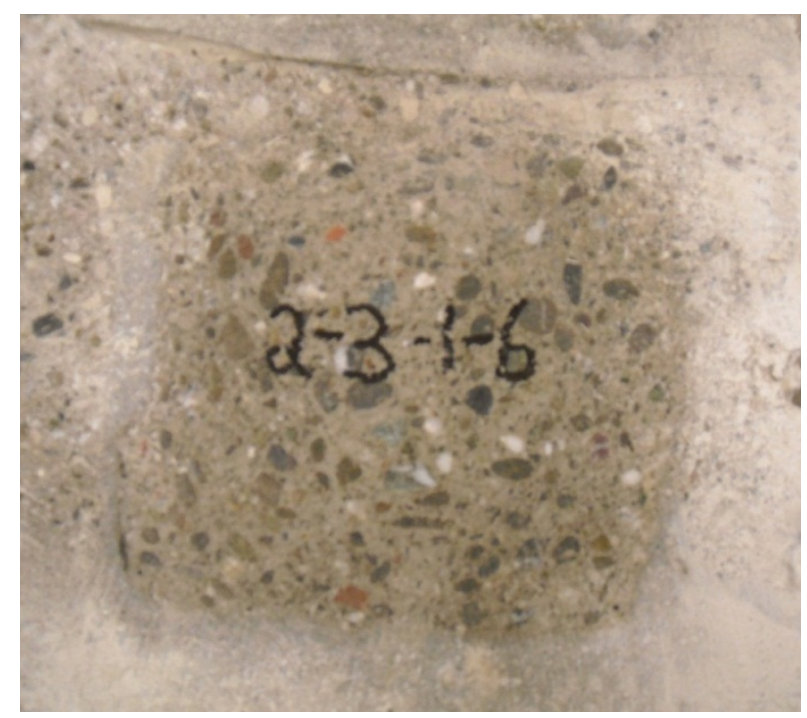

Figure GG: Top View of Wall Compression Specimen 2-3-1-6 before Final Cutting Source: Author Photo 


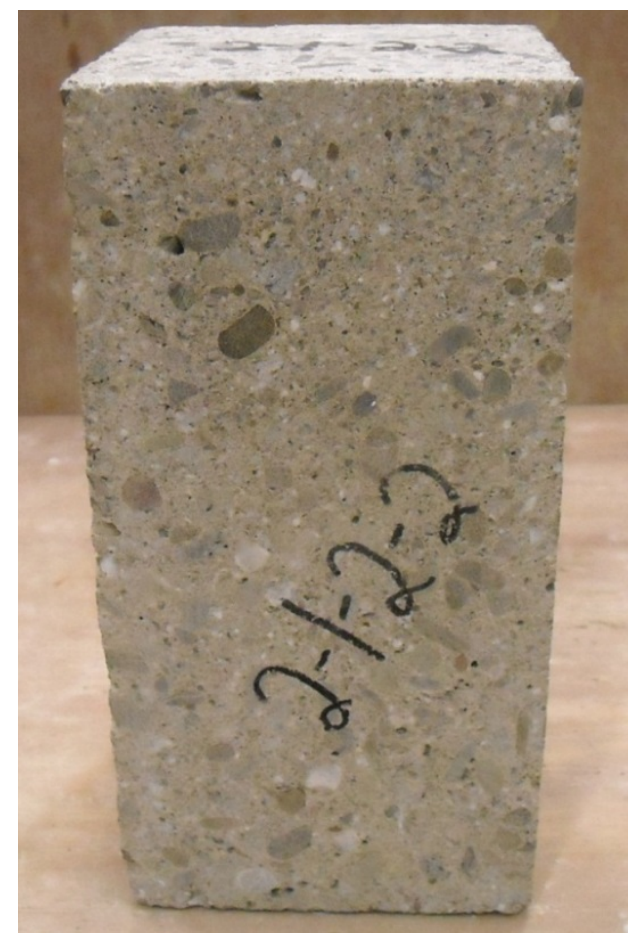

Figure HH: Side View of Wall Compression Specimen 2-1-2-2

Source: Author Photo

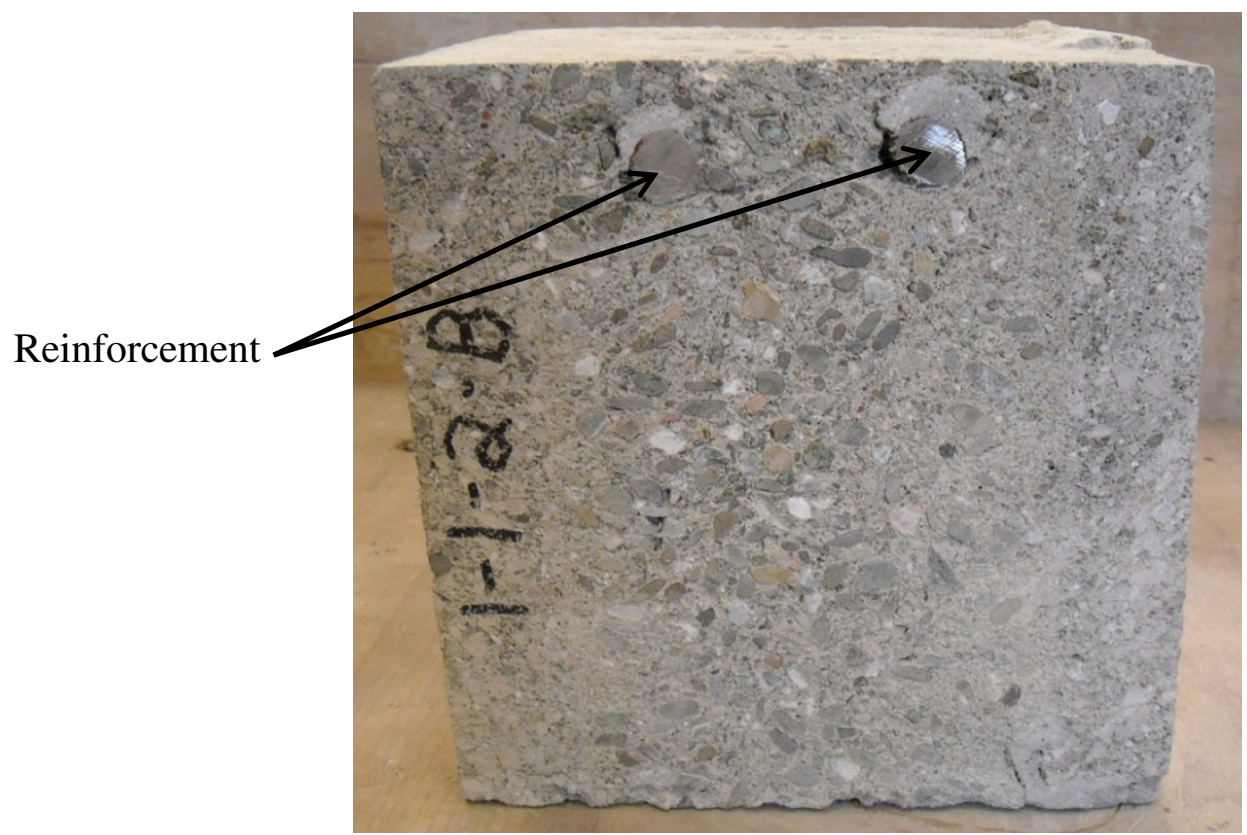

Figure II: Cross Section of Reinforcement Specimen 1-1-2-B Source: Author Photo

Performance of No Vibration/No Admixture Masonry Grout Containing High Replacement of Portland Cement with Fly Ash and Ground Granulated Blast Furnace Slag 


\subsubsection{Rebar Pullout}

Three rebar pullout specimens per grout mixture were tested. All specimens failed from the reinforcement pulling out of the grout, as shown in Figure JJ. The average bond strength for each mixture is shown in Figure KK and is provided in Appendix G.1. In order to determine if the grouts had the same relationship between compressive strength and bond strength, as in Equation 2, the average bond strength for each mixture was normalized to the square root of the average net corrected compressive strengths from The Wall Experiment, as provided in Appendix G.2.

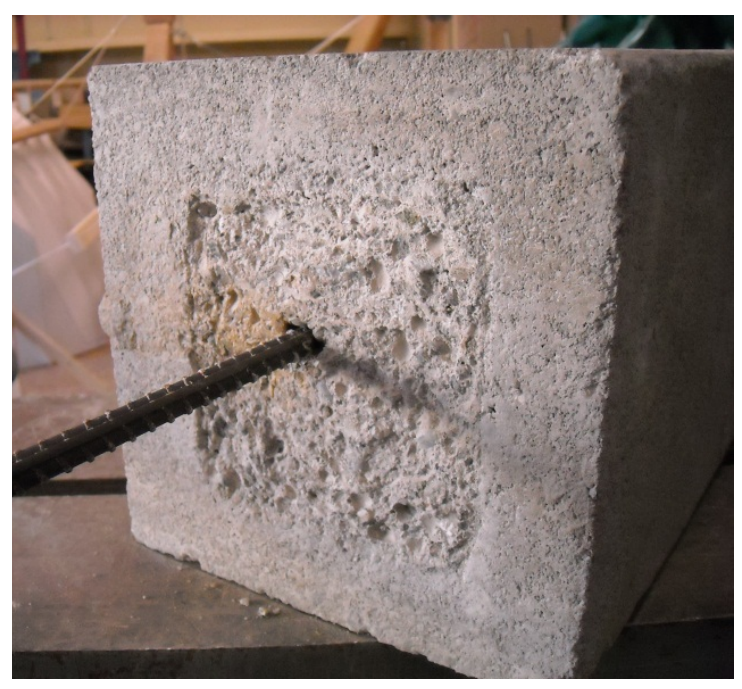

Figure JJ: Failure mode: Reinforcement Pull Out of Grout Source: Author Photo 


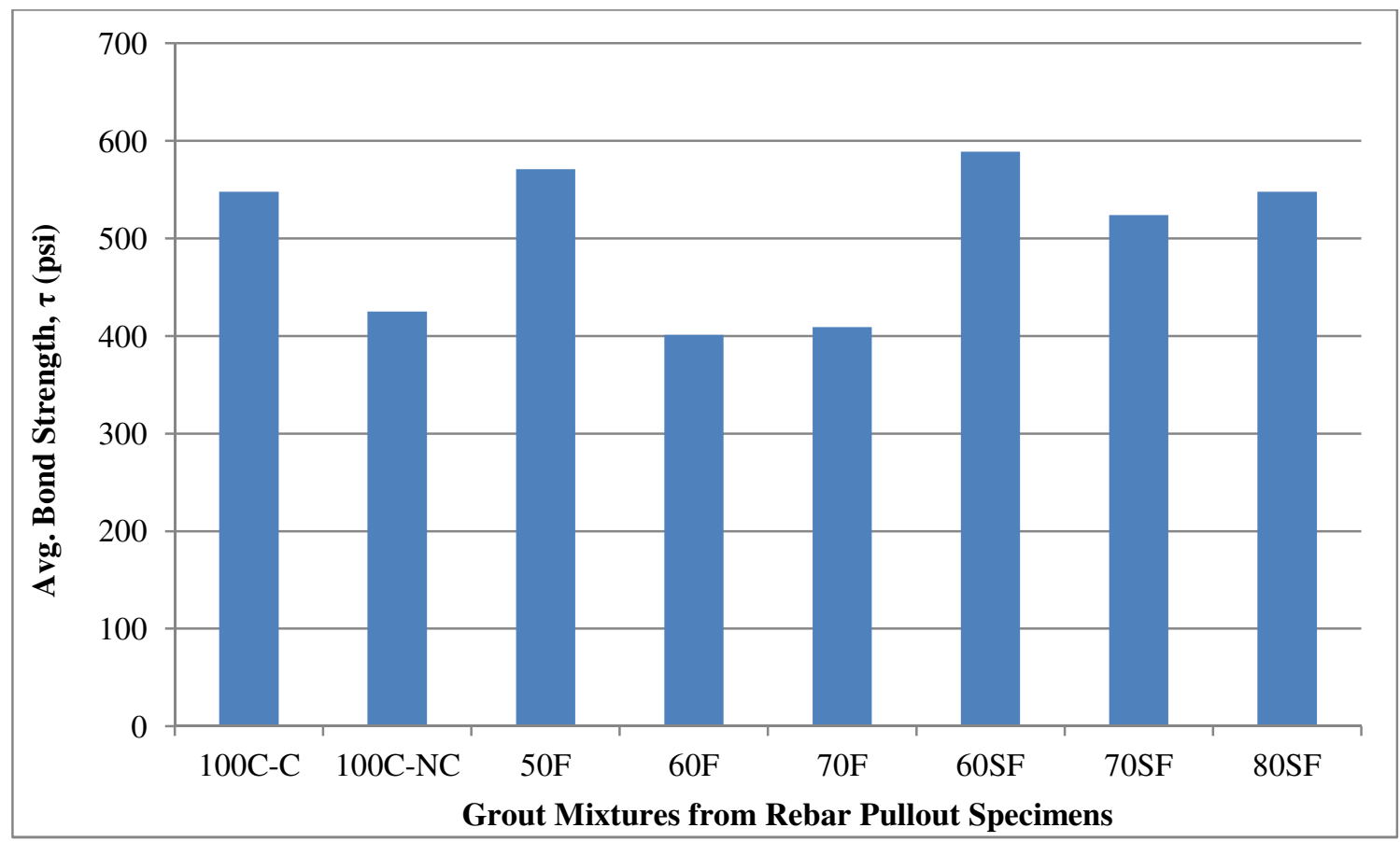

Figure KK: Average Bond Strength for Each Grout Mixture

Source: Author Figure

In all of the rebar pullout specimens, the reinforcement pulled out of the grout

before the reinforcing bars could yield. Since Equation 3 requires the reinforcement to yield in order to determine the minimum development length, the equation was modified, as shown in the equation

$$
l_{d}=\frac{0.13 d_{b}^{2}\left(\frac{T}{A_{s}}\right) \gamma}{K \sqrt{f_{g}}}
$$

Where $\quad l_{d}$ is the development length of straight reinforcement (in.),

$d_{b}$ is the nominal diameter of reinforcement (in.),

$T$ is the tensile axial force in the reinforcement (lb.),

$A_{s}$ is the effective cross-sectional area of reinforcement (in. ${ }^{2}$ ),

$\gamma$ is the reinforcement size factor (dimensionless),

$K$ is the dimension used to calculate reinforcement development (in.), and

$f_{g}$ is the compressive strength of grout (psi).

Performance of No Vibration/No Admixture Masonry Grout Containing High Replacement of Portland Cement with Fly Ash and Ground Granulated Blast Furnace Slag 
Even though the reinforcement did not yield, it still experienced an amount of stress, $f_{\mathrm{s}}$, at the applied load, $T$. Also, Equation 3 assumes a conventional grout compressive strength after 28 days of curing because the compressive strength should be above the code minimum of 2000 psi. From The Compression Experiment, the conventional grout passed the minimum after 28 day of curing, so the compressive strength, $f_{\mathrm{g}}$, after 28 days of curing was used in Equation 4. The fly ash and GGBFS replacement grouts all passed the code minimum after 56 days of curing, while the fly ash replacement grouts were not close to the minimum through 130 days of curing; therefore, the compressive strength of the fly ash, and fly ash and GGBFS replacement grouts after 56 days of curing were used in Equation 4 (provided in Appendix G.3).

The required theoretical development lengths of reinforcements, $l_{\mathrm{d}}$, found from Equation 4 were normalized to the actual embedment lengths, $l$, of the rebar pullout specimens, as shown in Figure LL. The normalized values less than 1.0 indicate that minimum development length for the applied load was achieved from the specimen, whereas values greater than 1.0 indicate that minimum development lengths for the applied load exceeded the embedment length of the specimen. 


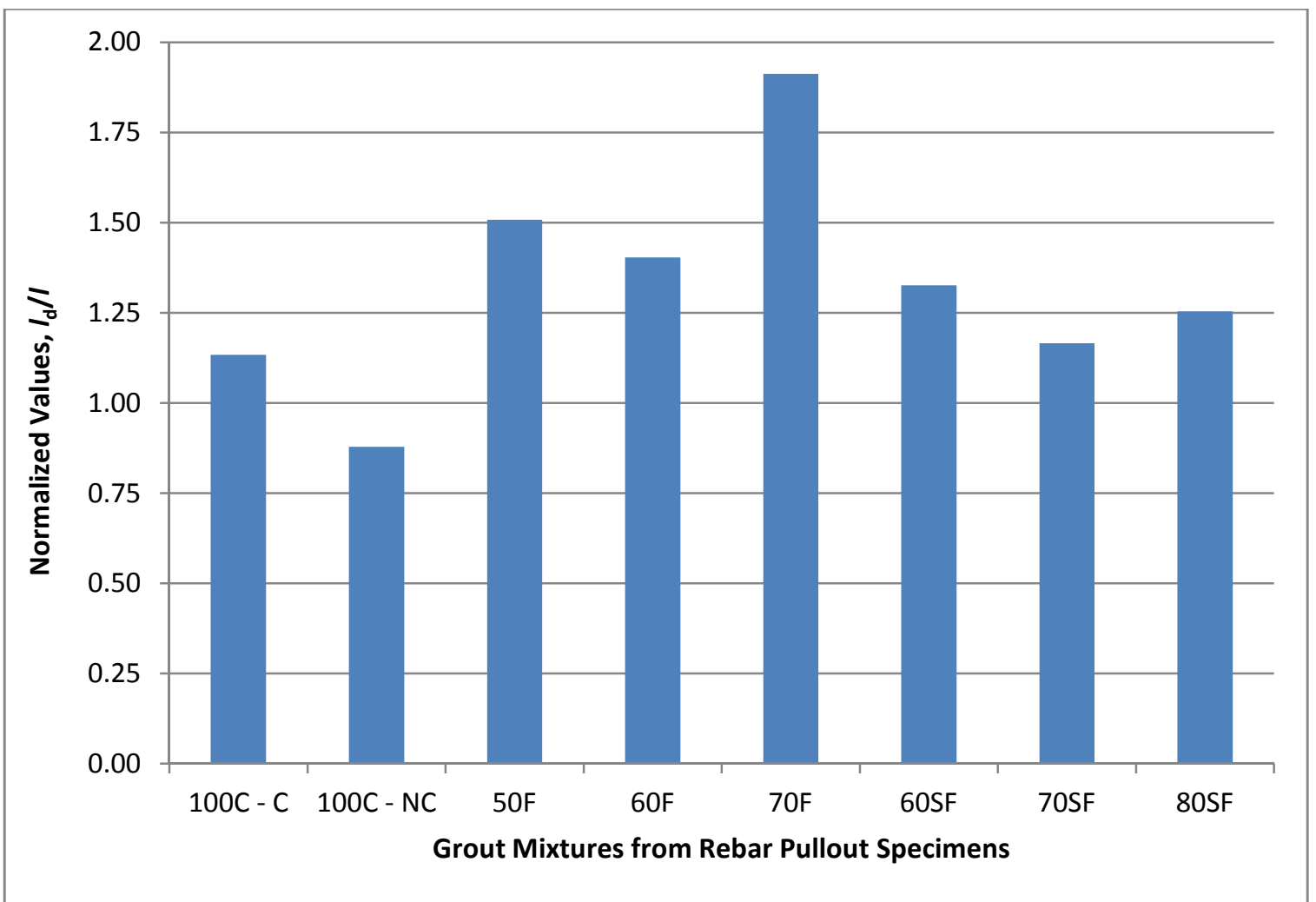

Figure LL: Average per Mixture of the Theoretical Development Lengths of Reinforcements Normalized to the Actual Embedment Lengths of the Rebar Pullout Specimens

Source: Author Figure 


\subsection{CONCLUSIONS}

The purpose of this thesis was to investigate if high Type F fly ash and/or GGBFS replacement of Portland cement in grout, without the use of admixtures and mechanical consolidation, can function as self-consolidating grout. After the completion of the experimental testing performed, the following conclusions were made.

Overall, the Type F fly ash and GGBFS replacements of Portland cement (60SF, 70SF, and 80SF) can function as self-consolidating grouts (with delayed curing time of 56 days), whereas the Type F fly ash replacements of Portland cement (50F, 60F, and 70F) are not viable self-consolidating grouts.

The experimental grouts, fly ash and/or GGBFS replacement of Portland cement satisfied the flow requirements of a self-consolidating grout mixture. All experimental grouts specimens were visually examined to have no segregation of aggregates and there were no significant variations of air void sizes throughout the height of each grout column. The experimental grouts were observed to have no significant differences in consolidation characteristics compared to the mechanically consolidated conventional grout. The average consolidation grades for all grout mixtures were less than 2.5, indicating that the consolidations were acceptable.

In order to be considered a self-consolidating grout according to ASTM C 476, the grout must provide a slump flow between 24 to 30 inches, a VSI of no more than 1, and a minimum compressive strength of 2000 psi after 28 days of curing. All experimental grouts met the slump flow and VSI requirements. From The Compression 
Experiment, the experimental grout mixtures where Portland cement was replaced with Type F fly ash and GGBFS (60SF, 70SF, and 80SF) met the minimum compressive strength requirement after 56 days of curing rather than 28 days. The compressive strengths of these specimens were significantly lower than the conventional grout but still met the code minimum. The experimental grout mixtures where Portland cement was replaced with Type F fly ash alone $(50 \mathrm{~F}, 60 \mathrm{~F}$, and $70 \mathrm{~F})$ does not appear to be a viable grout alternative because of their low compressive strength.

From the Wall Experiment, the results on compressive strengths of the grouts in produced similar results to the Compression Experiment for a curing time of 130 days, affirming the validity of the data obtained. Also, there was not any significant variation in compressive strengths of the samples taken from differing heights along the walls. The grout mixtures with fly ash and GGBFS replacement of cement after 130 days of curing were close to the 2000 psi minimum for both experiments. From the Wall Experiment, only the 60SF met the minimum compressive strength requirement and although the 70SF and 80SF did not differ significantly from each experiment, they did not met the requirement. The experimental grout mixtures where Portland cement was replaced with Type F fly ash alone did not meet the minimum compressive strength requirement for both experiments; therefore, they do not appear to be a viable grout alternative.

The average bond strengths from the rebar pullout specimens normalized to the square root of the average net corrected compressive strengths from The Wall 
Experiment match Equation 2 adequately. This indicates that the self-consolidating grouts share a similar relationship as the conventional grout, between their compressive strength and bond strength. The code (MSJC 2011) requires that the reinforcement must be anchored so as to fully develop the reinforcing bar to its yield stress. From required development lengths of reinforcement normalized to the embedment lengths of the rebar pullout specimens, as shown in Figure LL, the fly ash and GGBFS replacement grouts had similar normalized values as the consolidated conventional grout, whereas the fly ash replacement grouts had normalized values that were significantly greater. Therefore, the fly ash replacement grouts do not meet the code minimum development lengths required. 


\section{REFERENCES}

(ACI 506.2-95 1995) Specification for Shotcrete, American Concrete Institute, Michigan: 1995. Print.

(Bonen and Shah 2005) Bonen, David, and Surendra Shah. "Fresh and Hardened Properties of Self-Consolidating Concrete." Progress in Structural Engineering and Materials. (2005): Vol. 7.1: 14-26. Web. 18 April 2011.

(Bradfield 2011) Bradfield, Maribeth. "High Supplemental Cementitious Material (SCM) Grout Phase 2 and 3 Research." Masonry Chronicles. (2011). Web. 1 May 2011.

(Fang and Labi 2006) Fang, Chuanxin, and Samuel Labi. "Evaluating the Static Segregation Resistance of Hardened Self-Consolidating Concrete using Image Processing Technology". Transportation Research Board. (2006). Web. 17 May 2011.

(Foroughi, Dilmaghani, and Famili 2008) Foroughi-Asl, A., S. Dilmaghani, and H. Famili. "Bond Strength of Reinforcement Steel in Self-Compacting Concrete." International Journal of Civil Engineering. (2008): Vol. 6: 1. 1 February 2013.

(Greenwald et al. 2006) Greenwald, Jeffrey, Donald L. Breeding, M. Doug Luttrell, Douglas H. Ross, Christopher C. Carter, and Eman Rouhani. "Self-Consolidating Grout Investigation: Compressive Strength, Shear Bond, Consolidation and Flow." National Concrete Masonry Association. (2006): 04-355. Web. 18 April 2011.

(Hodgson et al. 2004) Hodgson, Donald, Anton Schindler, Dan Brown, and Mary Stroup-Gardiner. "The Feasibility of Using Self-Consolidating Concrete (SCC) in Dilled Shaft Applications". Transportation Research Board. (2004). Web. 17 May 2011.

(Horta 2005) Horta, Alen. Evaluation of Self-Consolidating Concrete for Bridge Structure Applications. MS Thesis. Georgia Institute of Technology, Atlanta, (2005). Web. 17 May 2011. 
(Huntzinger et al. 2009) Huntzinger, Deborah, John Gierke, Komar Kawatra, Timothy Eisele, and Lawrence Sutter. "Carbon Dioxide Sequestration in Cement Kiln Dust through Mineral Carbonation.” Environmental Science \& Technology. (2009): Vol. 43: 6. Web. 5 May 2011.

(IBC 2012) 2012 International Building Code. International Code Council, Illinois: 2011. Print.

(Kang and Kren 2007) Kang, Grace, and Alan Kren. "Structural Engineering Strategies Towards Sustainable Design.” SEAONC Sustainable Design Committee. (2007). Web. 2 February 2013.

(Khayat 1999) Khayat, K.H. "Workability, Testing, and Performance of SelfConsolidating Concrete.” ACI Materials Journal. (1999): 96-M43. Web. 18 April 2011.

(MSJC 2011) 2011 Building Code Requirements and Specification for Masonry Structures, Masonry Standards Joint Committee, Colorado: 2011. Print.

(Mwangi and Baltimore 2009) Mwangi, James, and Craig Baltimore. "Going Green in Concrete Masonry Construction by Use of Less Cement in Grout." Masonry Chronicles. (2009). Web. 20 April 2011.

(Rixom and Mailvaganam 1999) Rixom, Rodger, and Noel Mailvaganam. Chemical Admixtures for Concrete. New York: Routledge, 1999. Print.

(Ryan and Farnsworth 2003) Ryan, Robert, and Jennie Farnsworth. "Self-Consolidating Grout: This Isn't Your Father's Grout Mix." Mason Contractors Association of America. (2003). Web. 2 February 2013.

(Wight and MacGregor 2009) Wight, James K., and James G. MacGregor. Reinforced Concrete: Mechanics \& Design. $5^{\text {th }}$ Ed. New Jersey: Pearson Education, Inc., 2009. Print.

(Worrell et al. 2001) Worrell, Ernst, Lynn Price, Nathan Martin, Chris Hendriks, and Leticia Ozawa Meida. "Carbon Dioxide Emissions from the Global Cement Industry." Annual Review of Energy and the Environment. (2001): Vol. 26: 303-329. Web. 14 April 2011. 
American Society for Testing and Materials. ASTM Standards, ASTM International:

- A 615 Standard Specification for Deformed and Plain Carbon-Steel Bars for Concrete Reinforcement, 2012.

- C 90 Standard Specification for Loadbearing Concrete Masonry Units, 2011.

- C 143 Standard Test Method for Slump of Hydraulic-Cement Concrete, 2010.

- C 150 Standard Specifications for Portland Cement, 2012.

- C 157 Standard Test Method for Length Change of Hardened Hydraulic-Cement Mortar and Concrete, 2008.

- C 270 Standard Specification for Mortar for Unit Masonry, 2012.

- C 404 Standard Specification for Aggregates for Masonry Grout, 2011.

- C 476 Standard Specifications for Grout Masonry, 2010.

- C 618 Standard Specification for Coal Fly Ash and Raw or Calcined Natural Pozzolan for Use in Concrete, 2008.

- C 900 Standard Test Method for Pullout Strength of Hardened Concrete, 2012.

- C 989 Standard Specification for Slag Cement for Use in Concrete and Mortars, 2011.

- C 1019 Standard Test Method for Sampling and Testing Grout, 2011.

- C 1314 Standard Test Method for Compressive Strength of Masonry Prisms, 2011.

- C 1552 Standard Practice for Capping Concrete Masonry Units, Related Units and Masonry Prisms for Compression Testing, 2009.

- C 1611 Standard Test Method of Slump Flow of Self-Consolidating Concrete, 2009. 


\section{Appendices}

\section{Appendix A - Slump Flow Tests/Slump Tests}

\section{A.1 Slump Test Investigation of Conventional Grout}

\section{ASTM C 143 Test Report:}

Standard Test Method for Slump of Hydraulic-Cement Concrete
Date: $\quad$ 7/13/2012
Testing Lab:
CAED Concrete Lab

Grout Test Type:

Conventional Grout:

*No Admixtures

$\frac{100 \mathrm{C}}{0 \%}$ Replacement of Portland Cement

Used

\begin{tabular}{|c|c|c|c|c|c|}
\hline \multicolumn{6}{|c|}{ Conventional Grout Proportions by Volume } \\
\hline \multirow[t]{2}{*}{ Type } & \multirow[t]{2}{*}{$\begin{array}{l}\text { Parts by volume of } \\
\text { Portland Cement }\end{array}$} & \multirow[t]{2}{*}{$\begin{array}{l}\text { Parts by Volume of } \\
\text { Hydrated Lime or } \\
\text { Lime Putty }\end{array}$} & \multicolumn{2}{|c|}{$\begin{array}{l}\text { Aggregate, } \\
\text { Measured in a } \\
\text { Damp, Loose } \\
\text { Condition } \\
\end{array}$} & \multirow[t]{2}{*}{ Water } \\
\hline & & & Fine & Coarse & \\
\hline $100 \mathrm{C}$ & 1 & 0 & $\begin{array}{l}3 \text { times } \\
\text { the sum } \\
\text { of the } \\
\text { volumes } \\
\text { of } \\
\text { Portland } \\
\text { Cement }\end{array}$ & $\begin{array}{l}2 \text { times } \\
\text { the sum } \\
\text { of the } \\
\text { volumes } \\
\text { of } \\
\text { Portland } \\
\text { Cement }\end{array}$ & $\begin{array}{c}1.375 \\
\text { times the } \\
\text { sum of } \\
\text { the } \\
\text { volumes } \\
\text { of } \\
\text { Portland } \\
\text { Cement }\end{array}$ \\
\hline
\end{tabular}

\begin{tabular}{|c|c|}
\hline \multicolumn{2}{|c|}{ Slump Test } \\
\hline Test \# & Slump (in.) \\
\hline 1 & 9.75 \\
\hline 2 & 9.75 \\
\hline 3 & 9.50 \\
\hline Average & 9.75 \\
\hline
\end{tabular}

Performance of No Vibration/No Admixture Masonry Grout Containing High Replacement of Portland Cement with Fly Ash and Ground Granulated Blast Furnace Slag 


\section{A.2 Slump Flow Test Investigation of Experimental Grouts}

ASTM C 1611 Test Report:

Standard Test Method for Slump Flow of Self-Consolidating Concrete

Filling Procedure B (Inverted Mold)

Date: $\quad$ 7/13/2012

Testing Lab:

CAED Concrete Lab

Grout Test Type:

Experimental Grout:

$50 \mathrm{~F}$
$50 \%$ Replacement of Portland Cement

*No Admixtures Used

\begin{tabular}{|c|c|c|c|c|c|c|c|}
\hline \multicolumn{8}{|c|}{ Experimental Grout Proportions by Volume } \\
\hline \multirow{3}{*}{$\begin{array}{l}\text { Grout } \\
\text { Mixture }\end{array}$} & \multicolumn{3}{|c|}{$\begin{array}{c}\text { Parts by Volume of } \\
\text { Cementitious Material }\end{array}$} & \multirow{3}{*}{$\begin{array}{c}\text { Parts by } \\
\text { Volume of } \\
\text { Hydrated } \\
\text { Lime or Lime } \\
\text { Putty }\end{array}$} & \multirow{2}{*}{\multicolumn{2}{|c|}{$\begin{array}{l}\text { Aggregate, Measured in a } \\
\text { Damp, Loose Condition }\end{array}$}} & \multirow{3}{*}{ Water } \\
\hline & \multirow{2}{*}{$\begin{array}{l}\text { Portland } \\
\text { Cement }\end{array}$} & \multirow{2}{*}{$\begin{array}{c}\text { Type F } \\
\text { Fly } \\
\text { Ash }\end{array}$} & \multirow{2}{*}{ GGBFS } & & & & \\
\hline & & & & & Fine & Coarse & \\
\hline $50 \mathrm{~F}$ & 0.5 & 0.5 & 0 & 0 & $\begin{array}{l}3 \text { times the } \\
\text { sum of the } \\
\text { volumes of } \\
\text { cementitious } \\
\text { materials }\end{array}$ & $\begin{array}{l}2 \text { times the } \\
\text { sum of the } \\
\text { volumes of } \\
\text { cementitious } \\
\text { materials }\end{array}$ & $\begin{array}{c}1.375 \text { times } \\
\text { the sum of } \\
\text { the volumes } \\
\text { of } \\
\text { cementitious } \\
\text { materials }\end{array}$ \\
\hline
\end{tabular}

\begin{tabular}{|c|c|c|c|c|c|}
\hline \multicolumn{7}{|c|}{ Slump Flow Test } \\
\hline $\begin{array}{c}\text { Slump } \\
\text { Test \# }\end{array}$ & $\begin{array}{c}\text { Largest Diameter of } \\
\text { Circular Spread of } \\
\text { Grout, } \mathrm{d}_{1}, \text { (in.) }\end{array}$ & $\begin{array}{c}\text { Diameter } \\
\text { Perpendicular to } \\
\mathrm{d}_{1}, \mathrm{~d}_{2}, \text { (in.) }\end{array}$ & $\begin{array}{c}\text { Slump Flow, } \\
\text { Average of } \\
\mathrm{d}_{1} \text { and } \mathrm{d}_{2} \text { (in.) }\end{array}$ & $\begin{array}{c}\text { Visual } \\
\text { Stability Index }\end{array}$ & $\begin{array}{c}\mathrm{T}_{50}, \\
\text { (seconds) }\end{array}$ \\
\hline 1 & 26.50 & 24.50 & 25.5 & 1 & 1.0 \\
\hline 2 & 25.75 & 24.50 & 25.0 & 1 & 1.0 \\
\hline 3 & 26.50 & 25.75 & 26.0 & 1 & 1.0 \\
\hline \multicolumn{5}{|c|}{ Average: } \\
\hline
\end{tabular}

* Slump flow $=\left(\mathrm{d}_{1}+\mathrm{d}_{2}\right) / 2$

Performance of No Vibration/No Admixture Masonry Grout Containing High Replacement of

Portland Cement with Fly Ash and Ground Granulated Blast Furnace Slag 
A.2 Slump Flow Test Investigation of Experimental Grouts

ASTM C 1611 Test Report:

Standard Test Method for Slump Flow of Self-Consolidating Concrete

Filling Procedure B (Inverted Mold)

Date: $\quad 7 / 13 / 2012$

Testing Lab:

CAED Concrete Lab

Grout Test Type:

Experimental Grout:

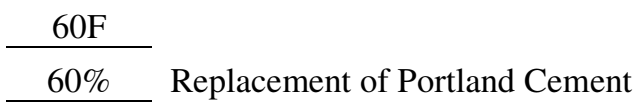

*No Admixtures Used

\begin{tabular}{|c|c|c|c|c|c|c|c|}
\hline \multicolumn{8}{|c|}{ Experimental Grout Proportions by Volume } \\
\hline \multirow{3}{*}{$\begin{array}{l}\text { Grout } \\
\text { Mixture }\end{array}$} & \multicolumn{3}{|c|}{$\begin{array}{c}\text { Parts by Volume of } \\
\text { Cementitious Material }\end{array}$} & \multirow{3}{*}{$\begin{array}{c}\text { Parts by } \\
\text { Volume of } \\
\text { Hydrated } \\
\text { Lime or Lime } \\
\text { Putty } \\
\end{array}$} & \multirow{2}{*}{\multicolumn{2}{|c|}{$\begin{array}{l}\text { Aggregate, Measured in a } \\
\text { Damp, Loose Condition }\end{array}$}} & \multirow{3}{*}{ Water } \\
\hline & \multirow{2}{*}{$\begin{array}{l}\text { Portland } \\
\text { Cement }\end{array}$} & \multirow{2}{*}{$\begin{array}{l}\text { Type F } \\
\text { Fly } \\
\text { Ash } \\
\end{array}$} & \multirow{2}{*}{ GGBFS } & & & & \\
\hline & & & & & Fine & Coarse & \\
\hline $60 \mathrm{~F}$ & 0.4 & 0.6 & 0 & 0 & $\begin{array}{l}3 \text { times the } \\
\text { sum of the } \\
\text { volumes of } \\
\text { cementitious } \\
\text { materials }\end{array}$ & $\begin{array}{l}2 \text { times the } \\
\text { sum of the } \\
\text { volumes of } \\
\text { cementitious } \\
\text { materials }\end{array}$ & $\begin{array}{l}1.375 \text { times } \\
\text { the sum of } \\
\text { the volumes } \\
\text { of } \\
\text { cementitious } \\
\text { materials }\end{array}$ \\
\hline
\end{tabular}

\begin{tabular}{|c|c|c|c|c|c|}
\hline \multicolumn{6}{|c|}{ Slump Flow Test } \\
\hline $\begin{array}{c}\text { Slump } \\
\text { Test \# }\end{array}$ & $\begin{array}{c}\text { Largest Diameter of } \\
\text { Circular Spread of } \\
\text { Grout, } \mathrm{d}_{1}, \text { (in.) }\end{array}$ & $\begin{array}{c}\text { Diameter } \\
\text { Perpendicular to } \\
\mathrm{d}_{1}, \mathrm{~d}_{2}, \text { (in.) }\end{array}$ & $\begin{array}{c}\text { Slump Flow, } \\
\text { Average of } \\
\mathrm{d}_{1} \text { and } \mathrm{d}_{2} \text { (in.)* }\end{array}$ & $\begin{array}{c}\text { Visual } \\
\text { Stability } \\
\text { Index }\end{array}$ & $\begin{array}{c}\mathrm{T}_{50}, \\
\text { (seconds) }\end{array}$ \\
\hline 1 & 29.25 & 27.25 & 28.5 & 1 & 1.0 \\
\hline 2 & 29.00 & 27.00 & 28.0 & 1 & 0.8 \\
\hline 3 & 29.00 & 27.50 & 28.5 & 1 & 0.8 \\
\hline
\end{tabular}

Average: $\quad 28.5 \mathrm{in}$.

* Slump flow $=\left(\mathrm{d}_{1}+\mathrm{d}_{2}\right) / 2$

Performance of No Vibration/No Admixture Masonry Grout Containing High Replacement of Portland Cement with Fly Ash and Ground Granulated Blast Furnace Slag 
A.2 Slump Flow Test Investigation of Experimental Grouts

ASTM C 1611 Test Report:

Standard Test Method for Slump Flow of Self-Consolidating Concrete

Filling Procedure B (Inverted Mold)

Date: $\quad 7 / 13 / 2012$

Testing Lab:

CAED Concrete Lab

Grout Test Type:

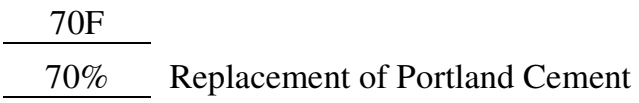

Experimental Grout:

*No Admixtures Used

\begin{tabular}{|c|c|c|c|c|c|c|c|}
\hline \multicolumn{8}{|c|}{ Experimental Grout Proportions by Volume } \\
\hline \multirow{3}{*}{$\begin{array}{l}\text { Grout } \\
\text { Mixture }\end{array}$} & \multicolumn{3}{|c|}{$\begin{array}{c}\text { Parts by Volume of } \\
\text { Cementitious Material }\end{array}$} & \multirow{3}{*}{$\begin{array}{c}\text { Parts by } \\
\text { Volume of } \\
\text { Hydrated } \\
\text { Lime or Lime } \\
\text { Putty }\end{array}$} & \multirow{2}{*}{\multicolumn{2}{|c|}{$\begin{array}{l}\text { Aggregate, Measured in a } \\
\text { Damp, Loose Condition }\end{array}$}} & \multirow{3}{*}{ Water } \\
\hline & \multirow{2}{*}{$\begin{array}{l}\text { Portland } \\
\text { Cement }\end{array}$} & \multirow{2}{*}{$\begin{array}{l}\text { Type } \\
\text { F Fly } \\
\text { Ash }\end{array}$} & \multirow{2}{*}{ GGBFS } & & & & \\
\hline & & & & & Fine & Coarse & \\
\hline $70 \mathrm{~F}$ & 0.3 & 0.7 & 0 & 0 & $\begin{array}{l}3 \text { times the } \\
\text { sum of the } \\
\text { volumes of } \\
\text { cementitious } \\
\text { materials }\end{array}$ & $\begin{array}{l}2 \text { times the } \\
\text { sum of the } \\
\text { volumes of } \\
\text { cementitious } \\
\text { materials }\end{array}$ & $\begin{array}{l}1.375 \text { times } \\
\text { the sum of } \\
\text { the volumes } \\
\text { of } \\
\text { cementitious } \\
\text { materials }\end{array}$ \\
\hline
\end{tabular}

\begin{tabular}{|c|c|c|c|c|c|}
\hline \multicolumn{7}{|c|}{ Slump Flow Test } \\
\hline $\begin{array}{c}\text { Slump } \\
\text { Test \# }\end{array}$ & $\begin{array}{c}\text { Largest Diameter of } \\
\text { Circular Spread of } \\
\text { Grout, } \mathrm{d}_{1} \text {, (in.) }\end{array}$ & $\begin{array}{c}\text { Diameter } \\
\text { Perpendicular to } \\
\mathrm{d}_{1}, \mathrm{~d}_{2}, \text { (in.) }\end{array}$ & $\begin{array}{c}\text { Slump Flow, } \\
\text { Average of } \\
\mathrm{d}_{1} \text { and } \mathrm{d}_{2} \text { (in.) }\end{array}$ & $\begin{array}{c}\text { Visual } \\
\text { Stability Index }\end{array}$ & $\begin{array}{c}\mathrm{T}_{50}, \\
\text { (seconds) }\end{array}$ \\
\hline 1 & 29.00 & 27.00 & 28.0 & 1 & 1.0 \\
\hline 2 & 30.50 & 29.00 & 30.0 & 1 & 0.8 \\
\hline 3 & 30.25 & 28.25 & 29.5 & 1 & 0.8 \\
\hline
\end{tabular}

Average:

29.0 in.

* Slump flow $=\left(\mathrm{d}_{1}+\mathrm{d}_{2}\right) / 2$

Performance of No Vibration/No Admixture Masonry Grout Containing High Replacement of Portland Cement with Fly Ash and Ground Granulated Blast Furnace Slag 
A.2 Slump Flow Test Investigation of Experimental Grouts

ASTM C 1611 Test Report:

Standard Test Method for Slump Flow of Self-Consolidating Concrete

Filling Procedure B (Inverted Mold)

Date: $\quad 7 / 13 / 2012$

Testing Lab:

CAED Concrete Lab

Grout Test Type:

Experimental Grout:

$60 \mathrm{SF}$
$60 \%$ Replacement of Portland Cement

*No Admixtures Used

\begin{tabular}{|c|c|c|c|c|c|c|c|}
\hline \multicolumn{7}{|c|}{ Experimental Grout Proportions by Volume } \\
\hline \multirow{2}{*}{$\begin{array}{c}\text { Grout } \\
\text { Mixture }\end{array}$} & \multicolumn{2}{|c|}{$\begin{array}{c}\text { Parts by Volume of } \\
\text { Cementitious Material }\end{array}$} & $\begin{array}{c}\text { Parts by } \\
\text { Volume of } \\
\text { Hydrated }\end{array}$ & \multicolumn{2}{|c|}{$\begin{array}{c}\text { Aggregate, Measured in a } \\
\text { Damp, Loose Condition }\end{array}$} & Water \\
\cline { 3 - 6 } & $\begin{array}{c}\text { Portland } \\
\text { Cement }\end{array}$ & $\begin{array}{c}\text { Type } \\
\text { F Fly } \\
\text { Ash }\end{array}$ & GGBFS & $\begin{array}{c}\text { Lime or Lime } \\
\text { Putty }\end{array}$ & Fine & Coarse & \\
\cline { 5 - 7 } & 0.4 & 0.15 & 0.45 & 0 & $\begin{array}{c}3 \text { times the } \\
\text { sum of the } \\
\text { volumes of } \\
\text { cementitious } \\
\text { materials }\end{array}$ & $\begin{array}{c}2 \text { times the } \\
\text { sum of the } \\
\text { volumes of } \\
\text { cementitious } \\
\text { materials }\end{array}$ & $\begin{array}{c}1.375 \text { times } \\
\text { the sum of } \\
\text { thelumes } \\
\text { of } \\
\text { cementitious } \\
\text { materials }\end{array}$ \\
\hline
\end{tabular}

\begin{tabular}{|c|c|c|c|c|c|}
\hline \multicolumn{6}{|c|}{ Slump Flow Test } \\
\hline $\begin{array}{c}\text { Slump } \\
\text { Test \# }\end{array}$ & $\begin{array}{c}\text { Largest Diameter of } \\
\text { Circular Spread of } \\
\text { Grout, } \mathrm{d}_{1} \text {, (in.) }\end{array}$ & $\begin{array}{c}\text { Diameter } \\
\text { Perpendicular to } \\
\mathrm{d}_{1}, \mathrm{~d}_{2} \text {, (in.) }\end{array}$ & $\begin{array}{c}\text { Slump Flow, } \\
\text { Average of } \\
\mathrm{d}_{1} \text { and } \mathrm{d}_{2} \text { (in.) }\end{array}$ & $\begin{array}{c}\text { Visual } \\
\text { Stability } \\
\text { Index }\end{array}$ & $\begin{array}{c}\mathrm{T}_{50}, \\
\text { (seconds) }\end{array}$ \\
\hline 1 & 25.00 & 23.00 & 24.0 & 1 & 1.0 \\
\hline 2 & 24.25 & 23.75 & 24.0 & 1 & 1.2 \\
\hline 3 & 25.75 & 24.75 & 25.5 & 1 & 1.2 \\
\hline
\end{tabular}

Average: $\quad 24.5 \mathrm{in}$.

* Slump flow $=\left(\mathrm{d}_{1}+\mathrm{d}_{2}\right) / 2$

Performance of No Vibration/No Admixture Masonry Grout Containing High Replacement of Portland Cement with Fly Ash and Ground Granulated Blast Furnace Slag 
A.2 Slump Flow Test Investigation of Experimental Grouts

ASTM C 1611 Test Report:

Standard Test Method for Slump Flow of Self-Consolidating Concrete

Filling Procedure B (Inverted Mold)

Date: $\quad 7 / 13 / 2012$

Testing Lab:

CAED Concrete Lab

Grout Test Type:

Experimental Grout:

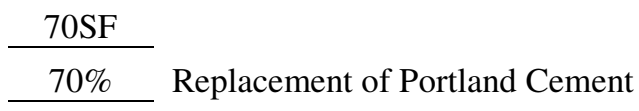

*No Admixtures Used

\begin{tabular}{|c|c|c|c|c|c|c|c|}
\hline \multicolumn{8}{|c|}{ Experimental Grout Proportions by Volume } \\
\hline \multirow{3}{*}{$\begin{array}{l}\text { Grout } \\
\text { Mixture }\end{array}$} & \multicolumn{3}{|c|}{$\begin{array}{c}\text { Parts by Volume of } \\
\text { Cementitious Material }\end{array}$} & \multirow{3}{*}{$\begin{array}{c}\text { Parts by } \\
\text { Volume of } \\
\text { Hydrated } \\
\text { Lime or Lime } \\
\text { Putty } \\
\end{array}$} & \multirow{2}{*}{\multicolumn{2}{|c|}{$\begin{array}{l}\text { Aggregate, Measured in a } \\
\text { Damp, Loose Condition }\end{array}$}} & \multirow{3}{*}{ Water } \\
\hline & \multirow{2}{*}{$\begin{array}{l}\text { Portland } \\
\text { Cement }\end{array}$} & \multirow{2}{*}{$\begin{array}{l}\text { Type F } \\
\text { Fly } \\
\text { Ash }\end{array}$} & \multirow{2}{*}{ GGBFS } & & & & \\
\hline & & & & & Fine & Coarse & \\
\hline $70 \mathrm{SF}$ & 0.3 & 0.175 & 0.525 & 0 & $\begin{array}{l}3 \text { times the } \\
\text { sum of the } \\
\text { volumes of } \\
\text { cementitious } \\
\text { materials }\end{array}$ & $\begin{array}{l}2 \text { times the } \\
\text { sum of the } \\
\text { volumes of } \\
\text { cementitious } \\
\text { materials }\end{array}$ & $\begin{array}{l}1.375 \text { times } \\
\text { the sum of } \\
\text { the volumes } \\
\text { of } \\
\text { cementitious } \\
\text { materials }\end{array}$ \\
\hline
\end{tabular}

\begin{tabular}{|c|c|c|c|c|c|}
\hline \multicolumn{6}{|c|}{ Slump Flow Test } \\
\hline $\begin{array}{c}\text { Slump } \\
\text { Test \# }\end{array}$ & $\begin{array}{c}\text { Largest Diameter of } \\
\text { Circular Spread of } \\
\text { Grout, } \mathrm{d}_{1}, \text { (in.) }\end{array}$ & $\begin{array}{c}\text { Diameter } \\
\text { Perpendicular to } \\
\mathrm{d}_{1}, \mathrm{~d}_{2}, \text { (in.) }\end{array}$ & $\begin{array}{c}\text { Slump Flow, } \\
\text { Average of } \\
\mathrm{d}_{1} \text { and } \mathrm{d}_{2} \text { (in.)* }\end{array}$ & $\begin{array}{c}\text { Visual } \\
\text { Stability } \\
\text { Index }\end{array}$ & $\begin{array}{c}\mathrm{T}_{50}, \\
\text { (seconds) }\end{array}$ \\
\hline 1 & 26.50 & 25.75 & 26.0 & 1 & 1.0 \\
\hline 2 & 26.50 & 25.25 & 26.0 & 1 & 1.0 \\
\hline 3 & 27.50 & 25.75 & 26.5 & 1 & 1.2 \\
\hline
\end{tabular}

Average: $\quad 26.0$ in.

* Slump flow $=\left(\mathrm{d}_{1}+\mathrm{d}_{2}\right) / 2$

Performance of No Vibration/No Admixture Masonry Grout Containing High Replacement of

Portland Cement with Fly Ash and Ground Granulated Blast Furnace Slag 
A.2 Slump Flow Test Investigation of Experimental Grouts

ASTM C 1611 Test Report:

Standard Test Method for Slump Flow of Self-Consolidating Concrete

Filling Procedure B (Inverted Mold)

Date: $\quad 7 / 13 / 2012$

Testing Lab:

CAED Concrete Lab

Grout Test Type:

Experimental Grout:

$80 \mathrm{SF}$

*No Admixtures Used

$80 \%$ Replacement of Portland Cement

\begin{tabular}{|c|c|c|c|c|c|c|c|}
\hline \multicolumn{8}{|c|}{ Experimental Grout Proportions by Volume } \\
\hline \multirow{3}{*}{$\begin{array}{l}\text { Grout } \\
\text { Mixture }\end{array}$} & \multicolumn{3}{|c|}{$\begin{array}{c}\text { Parts by Volume of } \\
\text { Cementitious Material }\end{array}$} & \multirow{3}{*}{$\begin{array}{l}\text { Parts by } \\
\text { Volume of } \\
\text { Hydrated } \\
\text { Lime or } \\
\text { Lime Putty }\end{array}$} & \multirow{2}{*}{\multicolumn{2}{|c|}{$\begin{array}{l}\text { Aggregate, Measured in a } \\
\text { Damp, Loose Condition }\end{array}$}} & \multirow{3}{*}{ Water } \\
\hline & \multirow{2}{*}{$\begin{array}{l}\text { Portland } \\
\text { Cement }\end{array}$} & \multirow{2}{*}{$\begin{array}{l}\text { Type F } \\
\text { Fly } \\
\text { Ash }\end{array}$} & \multirow{2}{*}{ GGBFS } & & & & \\
\hline & & & & & Fine & Coarse & \\
\hline $80 \mathrm{SF}$ & 0.2 & 0.2 & 0.6 & 0 & $\begin{array}{l}3 \text { times the } \\
\text { sum of the } \\
\text { volumes of } \\
\text { cementitious } \\
\text { materials }\end{array}$ & $\begin{array}{l}2 \text { times the } \\
\text { sum of the } \\
\text { volumes of } \\
\text { cementitious } \\
\text { materials }\end{array}$ & $\begin{array}{l}1.375 \text { times } \\
\text { the sum of } \\
\text { the volumes } \\
\text { of } \\
\text { cementitious } \\
\text { materials }\end{array}$ \\
\hline
\end{tabular}

\begin{tabular}{|c|c|c|c|c|c|}
\hline \multicolumn{7}{|c|}{ Slump Flow Test } \\
\hline $\begin{array}{c}\text { Slump } \\
\text { Flow } \#\end{array}$ & $\begin{array}{c}\text { Largest Diameter of } \\
\text { Circular Spread of } \\
\text { Grout, } \mathrm{d}_{1}, \text { (in.) }\end{array}$ & $\begin{array}{c}\text { Diameter } \\
\text { Perpendicular to } \\
\mathrm{d}_{1}, \mathrm{~d}_{2}, \text { (in.) }\end{array}$ & $\begin{array}{c}\text { Slump Flow, } \\
\text { Average of } \\
\mathrm{d}_{1} \text { and } \mathrm{d}_{2} \text { (in.)* }\end{array}$ & $\begin{array}{c}\text { Visual Stability } \\
\text { Index }\end{array}$ & $\begin{array}{c}\mathrm{T}_{50}, \\
\text { (seconds) }\end{array}$ \\
\hline 1 & 26.00 & 27.50 & 27.0 & 1 & 1.0 \\
\hline 2 & 27.00 & 26.00 & 26.5 & 1 & 1.2 \\
\hline 3 & 27.75 & 27.00 & 27.5 & 1 & 1.2 \\
\hline
\end{tabular}

Average: $\quad 27.0$ in.

* Slump flow $=\left(\mathrm{d}_{1}+\mathrm{d}_{2}\right) / 2$

Performance of No Vibration/No Admixture Masonry Grout Containing High Replacement of Portland Cement with Fly Ash and Ground Granulated Blast Furnace Slag 


\section{A.3 Slump Test for The Compression Experiment}

ASTM C 143 Test Report:

Standard Test Method for Slump of Hydraulic-Cement Concrete

Date: $\quad$ 8/8/2012 Testing Lab: $\quad$ CAED Concrete Lab

Grout Test Type: $\quad$ 100C

Conventional Grout: $\quad \quad 0 \% \quad$ Replacement of Portland Cement

*No Admixtures Used

Grout Proportions by Volume as in Appendix A.1

\begin{tabular}{|c|c|}
\hline \multicolumn{2}{|c|}{ Slump Test } \\
\hline Type & Slump (in.) \\
\hline 100C & 9.5 \\
\hline
\end{tabular}

Performance of No Vibration/No Admixture Masonry Grout Containing High Replacement of Portland Cement with Fly Ash and Ground Granulated Blast Furnace Slag 


\section{A.4 Slump Flow Tests for The Compression Experiment}

ASTM C 1611 Test Report:

Standard Test Method for Slump Flow of Self-Consolidating Concrete

Filling Procedure B (Inverted Mold)

Date:

$8 / 8 / 2012$

Testing Lab:

CAED Concrete Lab

*No Admixtures Used

Grout Proportions by Volume as in Appendix A.2

Portland Cement Replacement as in Table 2

\begin{tabular}{|c|c|c|c|c|c|}
\hline \multicolumn{5}{|c|}{ Slump Flow Test } \\
\hline $\begin{array}{c}\text { Grout } \\
\text { Mixture }\end{array}$ & $\begin{array}{c}\text { Largest Diameter of } \\
\text { Circular Spread of } \\
\text { Grout, } \mathrm{d}_{1}, \text { (in.) }\end{array}$ & $\begin{array}{c}\text { Diameter } \\
\text { Perpendicular to } \\
\mathrm{d}_{1}, \mathrm{~d}_{2}, \text { (in.) }\end{array}$ & $\begin{array}{c}\text { Slump Flow, } \\
\text { Average of } \\
\mathrm{d}_{1} \text { and } \mathrm{d}_{2} \text { (in.)* }\end{array}$ & $\begin{array}{c}\text { Visual } \\
\text { Stability } \\
\text { Index }\end{array}$ & $\begin{array}{c}\mathrm{T}_{50}, \\
\text { (seconds) }\end{array}$ \\
\hline $50 \mathrm{~F}$ & 25.50 & 25.25 & 25.5 & 1 & 1.0 \\
\hline $60 \mathrm{~F}$ & 29.50 & 27.50 & 28.5 & 1 & 1.0 \\
\hline $70 \mathrm{~F}$ & 30.25 & 28.25 & 29.5 & 1 & 1.0 \\
\hline $60 \mathrm{SF}$ & 25.00 & 23.00 & 24.0 & 1 & 1.2 \\
\hline $70 \mathrm{SF}$ & 27.00 & 25.00 & 26.0 & 1 & 1.0 \\
\hline $80 \mathrm{SF}$ & 28.00 & 26.25 & 27.0 & & 1 \\
\hline
\end{tabular}

* Slump flow $=\left(\mathrm{d}_{1}+\mathrm{d}_{2}\right) / 2$

Performance of No Vibration/No Admixture Masonry Grout Containing High Replacement of Portland Cement with Fly Ash and Ground Granulated Blast Furnace Slag 


\section{A.5 Slump Test for The Wall Experiment}

ASTM C 143 Test Report:

Standard Test Method for Slump of Hydraulic-Cement Concrete

Date: $\quad$ See Table $4 \quad$ Testing Lab: $\quad$ CAED Concrete Lab

Grout Test Type:

Conventional Grout:

*No Admixtures Used

Grout Proportions by Volume as in Appendix A.1

\begin{tabular}{|c|c|c|}
\hline \multicolumn{3}{|c|}{ Slump Test } \\
\hline $\begin{array}{c}\text { Grout } \\
\text { Mixture }\end{array}$ & $\begin{array}{c}\text { Grout } \\
\text { Column } \\
\text { ID }\end{array}$ & Slump (in.) \\
\hline 100C-C & $3-1-1$ & 10.00 \\
\hline 100C-C & $3-1-2$ & 9.75 \\
\hline 100C-C & $3-1-3$ & 9.75 \\
\hline 100C-NC & $3-2-1$ & 9.75 \\
\hline 100C-NC & $3-2-2$ & 9.75 \\
\hline 100C-C & $4-1-1$ & 9.75 \\
\hline 100C-NC & $4-2-1$ & 9.50 \\
\hline
\end{tabular}

$100 \mathrm{C}$

$0 \% \quad$ Replacement of Portland Cement 


\section{A.6 Slump Flow Tests for The Wall Experiment}

\section{ASTM C 1611 Test Report:}

Standard Test Method for Slump Flow of Self-Consolidating Concrete

Filling Procedure B (Inverted Mold)

Date:

See Table 4

Testing Lab:

CAED Concrete Lab

*No Admixtures Used

Grout Proportions by Volume as in Appendix A.2

Portland Cement Replacement as in Table 2

\begin{tabular}{|c|c|c|c|c|c|c|}
\hline \multicolumn{7}{|c|}{ Slump Flow Test } \\
\hline $\begin{array}{c}\text { Grout } \\
\text { Mixture }\end{array}$ & $\begin{array}{l}\text { Grout } \\
\text { Column } \\
\text { ID }\end{array}$ & $\begin{array}{l}\text { Largest Diameter } \\
\text { of Circular Spread } \\
\text { of Grout, } \mathrm{d}_{1} \text {, (in.) }\end{array}$ & $\begin{array}{c}\text { Diameter } \\
\text { Perpendicular } \\
\text { to } \mathrm{d}_{1}, \mathrm{~d}_{2} \text {, (in.) }\end{array}$ & $\begin{array}{c}\text { Slump Flow, } \\
\text { Average of } \\
\mathrm{d}_{1} \text { and } \mathrm{d}_{2} \\
\text { (in.) }{ }^{*}\end{array}$ & $\begin{array}{l}\text { Visual } \\
\text { Stability } \\
\text { Index }\end{array}$ & $\begin{array}{c}\mathrm{T}_{50}, \\
\text { (seconds) }\end{array}$ \\
\hline $50 \mathrm{~F}$ & $1-1-1$ & 25.00 & 25.50 & 25.5 & 1 & 1.0 \\
\hline $50 \mathrm{~F}$ & $1-1-2$ & 25.75 & 26.50 & 26.0 & 1 & 0.8 \\
\hline $60 \mathrm{~F}$ & $1-2-1$ & 28.00 & 28.00 & 28.0 & 1 & 1.4 \\
\hline $60 \mathrm{~F}$ & $1-2-2$ & 29.25 & 27.75 & 28.5 & 1 & 0.8 \\
\hline $70 \mathrm{~F}$ & $1-3-1$ & 29.50 & 29.00 & 29.5 & 1 & 1.0 \\
\hline $70 \mathrm{~F}$ & $1-3-2$ & 28.75 & 28.25 & 28.5 & 1 & 1.0 \\
\hline $60 \mathrm{SF}$ & $2-1-1$ & 24.00 & 24.00 & 24.0 & 1 & 1.6 \\
\hline $60 \mathrm{SF}$ & $2-1-2$ & 26.00 & 24.00 & 25.0 & 1 & 1.0 \\
\hline $70 \mathrm{SF}$ & $2-2-1$ & 26.50 & 26.00 & 26.5 & 1 & 0.8 \\
\hline 70SF & $2-2-2$ & 26.50 & 25.00 & 26.0 & 1 & 1.0 \\
\hline $80 \mathrm{SF}$ & $2-3-1$ & 27.25 & 26.00 & 27.0 & 1 & 1.2 \\
\hline $80 \mathrm{SF}$ & $2-3-2$ & 27.50 & 26.00 & 27.0 & 1 & 1.2 \\
\hline $50 \mathrm{~F}$ & $4-3-1$ & 26.50 & 25.50 & 26.0 & 1 & 1.2 \\
\hline $60 \mathrm{~F}$ & 4-4-1 & 28.75 & 27.50 & 28.0 & 1 & 0.8 \\
\hline $70 \mathrm{~F}$ & $4-5-1$ & 31.00 & 29.00 & 30.0 & 1 & 1.2 \\
\hline $60 \mathrm{SF}$ & $4-6-1$ & 24.50 & 23.50 & 24.0 & 1 & 1.2 \\
\hline $70 \mathrm{SF}$ & $4-7-1$ & 26.50 & 25.00 & 26.0 & 1 & 1.4 \\
\hline $80 \mathrm{SF}$ & 4-8-1 & 26.75 & 25.25 & 26.0 & 1 & 1.2 \\
\hline
\end{tabular}

* Slump flow $=\left(\mathrm{d}_{1}+\mathrm{d}_{2}\right) / 2$

Performance of No Vibration/No Admixture Masonry Grout Containing High Replacement of Portland Cement with Fly Ash and Ground Granulated Blast Furnace Slag 


\section{Appendix B - Grout Compressive Strengths from Compression Experiment}

\section{B.1 Compression Test Specimens: 7 Days of Curing}

Testing Lab:

CAED Concrete Lab

ASTM C 1019 Test Report:

Standard Test Method for Sampling and Testing Grout

Project Identification: Compression Experiment, Grout Compression Tests

Grout Information

Grout Type:

Date Grouted:

Date Tested:

Grout Slumps:

Method of Consolidation:

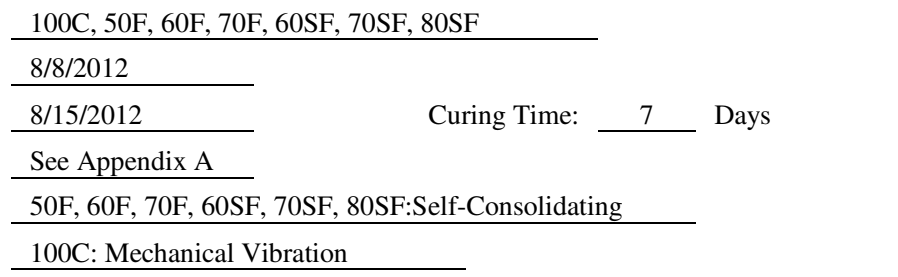

Tested Grout Properties:

\begin{tabular}{|c|c|c|c|c|c|c|c|c|c|c|c|}
\hline \multirow{2}{*}{$\begin{array}{l}\text { Grout } \\
\text { Sample }\end{array}$} & \multirow{2}{*}{$\begin{array}{c}\text { Age at } \\
\text { Test } \\
\text { (Days) }\end{array}$} & \multicolumn{2}{|c|}{$\begin{array}{l}\text { Cross Section } \\
\text { Dimensions }\end{array}$} & \multirow{2}{*}{$\begin{array}{l}\text { Avg. } \\
\text { Height } \\
\text { (in.) }\end{array}$} & \multirow{2}{*}{$\begin{array}{l}\text { Net } \\
\text { Area } \\
\left(\text { in }^{2}\right)\end{array}$} & \multirow{2}{*}{$\begin{array}{c}\text { Max } \\
\text { Load } \\
\text { (lb.) }\end{array}$} & \multirow{2}{*}{$\begin{array}{c}\text { Net } \\
\text { Comp. } \\
\text { Strength } \\
\text { (psi) }\end{array}$} & \multirow{2}{*}{$\begin{array}{c}\mathrm{h} / \mathrm{t} \\
\text { Ratio }\end{array}$} & \multirow{2}{*}{$\begin{array}{l}\mathrm{h} / \mathrm{t} \\
\mathrm{CF}^{*}\end{array}$} & \multirow{2}{*}{$\begin{array}{l}\text { Corrected } \\
\text { Net } \\
\text { Strength } \\
\text { (psi) }\end{array}$} & \multirow{2}{*}{$\begin{array}{c}\text { Avg. } \\
\text { Corrected } \\
\text { Net } \\
\text { Strength, } \\
f_{g}(\mathrm{psi})\end{array}$} \\
\hline & & $\begin{array}{l}\text { Avg. } \\
\text { Width } \\
\text { (in.) }\end{array}$ & $\begin{array}{l}\text { Avg. } \\
\text { Length } \\
\text { (in.) }\end{array}$ & & & & & & & & \\
\hline $100 \mathrm{C}-1$ & 7 & $313 / 16$ & $315 / 16$ & $71 / 2$ & 15.01 & 28000 & 1865 & 1.97 & 0.99 & 1848 & \multirow{3}{*}{1784} \\
\hline $100 \mathrm{C}-2$ & 7 & 4 & 4 & $79 / 16$ & 16.00 & 29000 & 1813 & 1.89 & 0.97 & 1757 & \\
\hline $100 \mathrm{C}-3$ & 7 & $37 / 8$ & $315 / 16$ & $79 / 16$ & 15.26 & 27000 & 1770 & 1.95 & 0.99 & 1746 & \\
\hline 50F-1 & 7 & $33 / 4$ & $315 / 16$ & $79 / 16$ & 14.77 & 8000 & 542 & 2.02 & 1.00 & 543 & \multirow{3}{*}{606} \\
\hline $50 \mathrm{~F}-2$ & 7 & $315 / 16$ & 4 & $71 / 2$ & 15.75 & 9000 & 571 & 1.90 & 0.97 & 556 & \\
\hline $50 \mathrm{~F}-3$ & 7 & $37 / 8$ & $37 / 8$ & $7 \quad 1 / 2$ & 15.02 & 11000 & 733 & 1.94 & 0.98 & 719 & \\
\hline $60 \mathrm{~F}-1$ & 7 & $315 / 16$ & $315 / 16$ & $7 \quad 1 / 2$ & 15.50 & 7000 & 451 & 1.90 & 0.97 & 439 & \multirow{3}{*}{391} \\
\hline $60 \mathrm{~F}-2$ & 7 & $33 / 4$ & $315 / 16$ & $77 / 16$ & 14.77 & 5000 & 339 & 1.98 & 1.00 & 337 & \\
\hline $60 \mathrm{~F}-3$ & 7 & $313 / 16$ & $315 / 16$ & $71 / 2$ & 15.01 & 6000 & 400 & 1.97 & 0.99 & 396 & \\
\hline $70 \mathrm{~F}-1$ & 7 & $35 / 8$ & $311 / 16$ & $77 / 16$ & 13.37 & 3000 & 224 & 2.05 & 1.00 & 225 & \multirow{3}{*}{224} \\
\hline $70 \mathrm{~F}-2$ & 7 & $35 / 8$ & $311 / 16$ & $77 / 16$ & 13.37 & 3000 & 224 & 2.05 & 1.00 & 225 & \\
\hline $70 F-3$ & 7 & $311 / 16$ & $311 / 16$ & $77 / 16$ & 13.60 & 3000 & 221 & 2.02 & 1.00 & 221 & \\
\hline 60SF-1 & 7 & $313 / 16$ & $313 / 16$ & $79 / 16$ & 14.54 & 14000 & 963 & 1.98 & 1.00 & 959 & \multirow{3}{*}{944} \\
\hline 60SF-2 & 7 & $3 \quad 3 / 4$ & $313 / 16$ & $\begin{array}{ll}7 & 1 / 2 \\
\end{array}$ & 14.30 & 13000 & 909 & 2.00 & 1.00 & 909 & \\
\hline 60SF-3 & 7 & $37 / 8$ & $315 / 16$ & $7 \quad 1 / 2$ & 15.26 & 15000 & 983 & 1.94 & 0.98 & 965 & \\
\hline 70SF-1 & 7 & $315 / 16$ & $315 / 16$ & $71 / 2$ & 15.50 & 16000 & 1032 & 1.90 & 0.97 & 1004 & \multirow{3}{*}{1062} \\
\hline 70SF-2 & 7 & $315 / 16$ & 4 & $7 \quad 1 / 2$ & 15.75 & 17000 & 1079 & 1.90 & 0.97 & 1051 & \\
\hline 70SF-3 & 7 & $315 / 16$ & $315 / 16$ & $7 \quad 1 / 2$ & 15.50 & 18000 & 1161 & 1.90 & 0.97 & 1130 & \\
\hline 80SF-1 & 7 & $313 / 16$ & $315 / 16$ & $71 / 2$ & 15.01 & 15000 & 999 & 1.97 & 0.99 & 990 & \multirow{3}{*}{979} \\
\hline 80SF-2 & 7 & $37 / 8$ & $315 / 16$ & $7 \quad 1 / 2$ & 15.26 & 15000 & 983 & 1.94 & 0.98 & 965 & \\
\hline 80SF-3 & 7 & $37 / 8$ & $37 / 8$ & $71 / 2$ & 15.02 & 15000 & 999 & 1.94 & 0.98 & 981 & \\
\hline
\end{tabular}

* Height to thickness correction factor from Table 1 of ASTM C 1314.

Values have been linearly interpolated as necessary

Performance of No Vibration/No Admixture Masonry Grout Containing High Replacement of Portland Cement with Fly Ash and Ground Granulated Blast Furnace Slag 


\title{
B.2 Compression Test Specimens: 14 Days of Curing
}

Testing Lab:

\author{
CAED Concrete Lab
}

ASTM C 1019 Test Report:

Standard Test Method for Sampling and Testing Grout

Project Identification: Compression Experiment, Grout Compression Tests

Grout Information

Grout Type:

Date Grouted:

Date Tested:

Grout Slumps:

Method of Consolidation:

100C, 50F, 60F, 70F, 60SF, 70SF, 80SF

$8 / 8 / 2012$

$8 / 22 / 2012$

See Appendix A

Curing Time: 14 Days

50F, 60F, 70F, 60SF, 70SF, 80SF:Self-Consolidating

Tested Grout Properties:

100C: Mechanical Vibration

\begin{tabular}{|c|c|c|c|c|c|c|c|c|c|c|c|}
\hline \multirow{2}{*}{$\begin{array}{c}\text { Grout } \\
\text { Sample }\end{array}$} & \multirow{2}{*}{$\begin{array}{c}\text { Age at } \\
\text { Test } \\
\text { (Days) }\end{array}$} & \multicolumn{2}{|c|}{$\begin{array}{c}\text { Cross Section } \\
\text { Dimensions }\end{array}$} & \multirow{2}{*}{$\begin{array}{l}\text { Avg. } \\
\text { Height } \\
\text { (in.) }\end{array}$} & \multirow{2}{*}{$\begin{array}{l}\text { Net } \\
\text { Area } \\
\left(\mathrm{in}^{2}\right)\end{array}$} & \multirow{2}{*}{$\begin{array}{c}\text { Max } \\
\text { Load } \\
\text { (lb.) }\end{array}$} & \multirow{2}{*}{$\begin{array}{c}\text { Net } \\
\text { Comp. } \\
\text { Strength } \\
\text { (psi) }\end{array}$} & \multirow{2}{*}{$\begin{array}{c}\mathrm{h} / \mathrm{t} \\
\text { Ratio }\end{array}$} & \multirow{2}{*}{$\begin{array}{c}\mathrm{h} / \mathrm{t} \\
\mathrm{CF}^{*}\end{array}$} & \multirow{2}{*}{$\begin{array}{l}\text { Corrected } \\
\text { Net } \\
\text { Strength } \\
\text { (psi) }\end{array}$} & \multirow{2}{*}{$\begin{array}{c}\text { Avg. } \\
\text { Corrected } \\
\text { Net } \\
\text { Strength, } \\
f_{g}(\mathrm{psi})\end{array}$} \\
\hline & & $\begin{array}{l}\text { Avg. } \\
\text { Width } \\
\text { (in.) }\end{array}$ & $\begin{array}{l}\text { Avg. } \\
\text { Length } \\
\text { (in.) }\end{array}$ & & & & & & & & \\
\hline $100 \mathrm{C}-1$ & 14 & $313 / 16$ & $315 / 16$ & $71 / 2$ & 15.01 & 32000 & 2132 & 1.97 & 0.99 & 2112 & \multirow{3}{*}{2176} \\
\hline $100 \mathrm{C}-2$ & 14 & $37 / 8$ & $315 / 16$ & $7 \quad 1 / 2$ & 15.26 & 36000 & 2359 & 1.94 & 0.98 & 2317 & \\
\hline $100 \mathrm{C}-3$ & 14 & $37 / 8$ & 4 & $79 / 16$ & 15.50 & 33000 & 2129 & 1.95 & 0.99 & 2100 & \\
\hline $50 \mathrm{~F}-1$ & 14 & $313 / 16$ & $315 / 16$ & $77 / 16$ & 15.01 & 15000 & 999 & 1.95 & 0.99 & 985 & \multirow{3}{*}{962} \\
\hline $50 \mathrm{~F}-2$ & 14 & $37 / 8$ & $315 / 16$ & $77 / 16$ & 15.26 & 15000 & 983 & 1.92 & 0.98 & 961 & \\
\hline $50 \mathrm{~F}-3$ & 14 & $313 / 16$ & $37 / 8$ & $71 / 2$ & 14.77 & 14000 & 948 & 1.97 & 0.99 & 939 & \\
\hline $60 \mathrm{~F}-1$ & 14 & $313 / 16$ & $37 / 8$ & $7 \quad 1 / 2$ & 14.77 & 8000 & 542 & 1.97 & 0.99 & 537 & \multirow{3}{*}{546} \\
\hline $60 \mathrm{~F}-2$ & 14 & $313 / 16$ & $313 / 16$ & $\begin{array}{ll}7 & 1 / 2\end{array}$ & 14.54 & 8000 & 550 & 1.97 & 0.99 & 545 & \\
\hline $60 \mathrm{~F}-3$ & 14 & $33 / 4$ & $313 / 16$ & $77 / 16$ & 14.30 & 8000 & 560 & 1.98 & 1.00 & 557 & \\
\hline $70 \mathrm{~F}-1$ & 14 & $311 / 16$ & $311 / 16$ & $71 / 2$ & 13.60 & 4000 & 294 & 2.03 & 1.00 & 295 & \multirow{3}{*}{295} \\
\hline $70 \mathrm{~F}-2$ & 14 & $35 / 8$ & $3 \quad 3 / 4$ & $75 / 16$ & 13.59 & 4000 & 294 & 2.02 & 1.00 & 295 & \\
\hline $70 \mathrm{~F}-3$ & 14 & $35 / 8$ & $33 / 4$ & $77 / 16$ & 13.59 & 4000 & 294 & 2.05 & 1.00 & 295 & \\
\hline 60SF-1 & 14 & $313 / 16$ & $37 / 8$ & $79 / 16$ & 14.77 & 21000 & 1421 & 1.98 & 1.00 & 1415 & \multirow{3}{*}{1404} \\
\hline $60 \mathrm{SF}-2$ & 14 & $37 / 8$ & $37 / 8$ & $75 / 8$ & 15.02 & 22000 & 1465 & 1.97 & 0.99 & 1452 & \\
\hline $60 \mathrm{SF}-3$ & 14 & $37 / 8$ & $315 / 16$ & $77 / 16$ & 15.26 & 21000 & 1376 & 1.92 & 0.98 & 1345 & \\
\hline $70 \mathrm{SF}-1$ & 14 & $313 / 16$ & 4 & $7 \quad 1 / 2$ & 15.25 & 24000 & 1574 & 1.97 & 0.99 & 1559 & \multirow{3}{*}{1535} \\
\hline $70 \mathrm{SF}-2$ & 14 & $37 / 8$ & $315 / 16$ & $7 \quad 1 / 2$ & 15.26 & 24000 & 1573 & 1.94 & 0.98 & 1545 & \\
\hline $70 \mathrm{SF}-3$ & 14 & $313 / 16$ & $313 / 16$ & $\begin{array}{ll}7 & 1 / 2 \\
\end{array}$ & 14.54 & 22000 & 1514 & 1.97 & 0.99 & 1500 & \\
\hline $80 \mathrm{SF}-1$ & 14 & $315 / 16$ & $315 / 16$ & $7 \quad 1 / 2$ & 15.50 & 22000 & 1419 & 1.90 & 0.97 & 1381 & \multirow{3}{*}{1409} \\
\hline 80 SF- 2 & 14 & $313 / 16$ & $37 / 8$ & $77 / 16$ & 14.77 & 22000 & 1489 & 1.95 & 0.99 & 1469 & \\
\hline 80SF-3 & 14 & $33 / 4$ & $37 / 8$ & $71 / 2$ & 14.53 & 20000 & 1376 & 2.00 & 1.00 & 1376 & \\
\hline
\end{tabular}

* Height to thickness correction factor from Table 1 of ASTM C 1314.

Values have been linearly interpolated as necessary

Performance of No Vibration/No Admixture Masonry Grout Containing High Replacement of Portland Cement with Fly Ash and Ground Granulated Blast Furnace Slag 


\title{
B.3 Compression Test Specimens: 28 Days of Curing
}

Testing Lab:

\author{
CAED Concrete Lab
}

ASTM C 1019 Test Report:

Standard Test Method for Sampling and Testing Grout

Project Identification: Compression Experiment, Grout Compression Tests

Grout Information

Grout Type:

Date Grouted:

Date Tested:

Grout Slumps:

Method of Consolidation:

100C, 50F, 60F, 70F, 60SF, 70SF, 80SF

\begin{tabular}{lll}
$\frac{8 / 8 / 2012}{9 / 5 / 2012}$ & Curing Time: 28 Days \\
\hline See Appendix A & \\
\hline 50F, 60F, 70F, 60SF, 70SF, 80SF:Self-Consolidating & \\
\hline 100C: Mechanical Vibration &
\end{tabular}

Tested Grout Properties:

\begin{tabular}{|c|c|c|c|c|c|c|c|c|c|c|c|}
\hline \multirow{2}{*}{$\begin{array}{c}\text { Grout } \\
\text { Sample }\end{array}$} & \multirow{2}{*}{$\begin{array}{c}\text { Age at } \\
\text { Test } \\
\text { (Days) }\end{array}$} & \multicolumn{2}{|c|}{$\begin{array}{c}\text { Cross Section } \\
\text { Dimensions }\end{array}$} & \multirow{2}{*}{$\begin{array}{l}\text { Avg. } \\
\text { Height } \\
\text { (in.) }\end{array}$} & \multirow{2}{*}{$\begin{array}{l}\text { Net } \\
\text { Area } \\
\left(\mathrm{in}^{2}\right)\end{array}$} & \multirow{2}{*}{$\begin{array}{c}\text { Max } \\
\text { Load } \\
\text { (lb.) }\end{array}$} & \multirow{2}{*}{$\begin{array}{c}\text { Net } \\
\text { Comp. } \\
\text { Strength } \\
\text { (psi) }\end{array}$} & \multirow{2}{*}{$\begin{array}{c}\mathrm{h} / \mathrm{t} \\
\text { Ratio }\end{array}$} & \multirow{2}{*}{$\begin{array}{c}\mathrm{h} / \mathrm{t} \\
\mathrm{CF}^{*}\end{array}$} & \multirow{2}{*}{$\begin{array}{l}\text { Corrected } \\
\text { Net } \\
\text { Strength } \\
\text { (psi) }\end{array}$} & \multirow{2}{*}{$\begin{array}{c}\text { Avg. } \\
\text { Corrected } \\
\text { Net } \\
\text { Strength, } \\
f_{g} \text { (psi) }\end{array}$} \\
\hline & & $\begin{array}{l}\text { Avg. } \\
\text { Width } \\
\text { (in.) }\end{array}$ & $\begin{array}{l}\text { Avg. } \\
\text { Length } \\
\text { (in.) }\end{array}$ & & & & & & & & \\
\hline $100 \mathrm{C}-1$ & 28 & $313 / 16$ & $313 / 16$ & $79 / 16$ & 14.54 & 38000 & 2614 & 1.98 & 1.00 & 2602 & \multirow{3}{*}{2531} \\
\hline $100 \mathrm{C}-2$ & 28 & $315 / 16$ & $315 / 16$ & $79 / 16$ & 15.50 & 37000 & 2386 & 1.92 & 0.98 & 2333 & \\
\hline $100 \mathrm{C}-3$ & 28 & $33 / 4$ & $313 / 16$ & $7 \quad 1 / 2$ & 14.30 & 38000 & 2658 & 2.00 & 1.00 & 2658 & \\
\hline $50 \mathrm{~F}-1$ & 28 & $313 / 16$ & $37 / 8$ & $77 / 16$ & 14.77 & 19000 & 1286 & 1.95 & 0.99 & 1268 & \multirow{3}{*}{1278} \\
\hline $50 \mathrm{~F}-2$ & 28 & $33 / 4$ & $37 / 8$ & $7 \quad 1 / 2$ & 14.53 & 19000 & 1308 & 2.00 & 1.00 & 1308 & \\
\hline $50 \mathrm{~F}-3$ & 28 & $3 \quad 3 / 4$ & $313 / 16$ & $\begin{array}{ll}7 & 1 / 2 \\
\end{array}$ & 14.30 & 18000 & 1259 & 2.00 & 1.00 & 1259 & \\
\hline $60 \mathrm{~F}-1$ & 28 & $3 \quad 3 / 4$ & $3 \quad 3 / 4$ & $7 \quad 1 / 2$ & 14.06 & 11000 & 782 & 2.00 & 1.00 & 782 & \multirow{3}{*}{715} \\
\hline $60 \mathrm{~F}-2$ & 28 & $3 \quad 3 / 4$ & $313 / 16$ & $73 / 8$ & 14.30 & 10000 & 699 & 1.97 & 0.99 & 693 & \\
\hline $60 \mathrm{~F}-3$ & 28 & $313 / 16$ & $37 / 8$ & $7 \quad 1 / 2$ & 14.77 & 10000 & 677 & 1.97 & 0.99 & 671 & \\
\hline $70 \mathrm{~F}-1$ & 28 & $311 / 16$ & $33 / 4$ & $73 / 8$ & 13.83 & 5000 & 362 & 2.00 & 1.00 & 362 & \multirow{3}{*}{398} \\
\hline $70 \mathrm{~F}-2$ & 28 & $35 / 8$ & $3 \quad 3 / 4$ & $73 / 8$ & 13.59 & 6000 & 441 & 2.03 & 1.00 & 443 & \\
\hline $70 \mathrm{~F}-3$ & 28 & $39 / 16$ & $35 / 8$ & $73 / 8$ & 12.91 & 5000 & 387 & 2.07 & 1.01 & 389 & \\
\hline $60 \mathrm{SF}-1$ & 28 & $37 / 8$ & $37 / 8$ & $79 / 16$ & 15.02 & 25000 & 1665 & 1.95 & 0.99 & 1642 & \multirow{3}{*}{1659} \\
\hline $60 \mathrm{SF}-2$ & 28 & $313 / 16$ & $37 / 8$ & $79 / 16$ & 14.77 & 25000 & 1692 & 1.98 & 1.00 & 1684 & \\
\hline 60 SF-3 & 28 & $313 / 16$ & $315 / 16$ & $7 \quad 1 / 2$ & 15.01 & 25000 & 1665 & 1.97 & 0.99 & 1650 & \\
\hline $70 \mathrm{SF}-1$ & 28 & $313 / 16$ & $315 / 16$ & $7 \quad 1 / 2$ & 15.01 & 29000 & 1932 & 1.97 & 0.99 & 1914 & \multirow{3}{*}{1900} \\
\hline 70 SF-2 & 28 & $313 / 16$ & $37 / 8$ & $71 / 2$ & 14.77 & 28000 & 1895 & 1.97 & 0.99 & 1878 & \\
\hline $70 \mathrm{SF}-3$ & 28 & $313 / 16$ & $313 / 16$ & $7 \quad 1 / 2$ & 14.54 & 28000 & 1926 & 1.97 & 0.99 & 1909 & \\
\hline 80SF-1 & 28 & $313 / 16$ & $37 / 8$ & $7 \quad 1 / 2$ & 14.77 & 27000 & 1828 & 1.97 & 0.99 & 1811 & \multirow{3}{*}{1722} \\
\hline $80 \mathrm{SF}-2$ & 28 & $313 / 16$ & 4 & $77 / 16$ & 15.25 & 28000 & 1836 & 1.95 & 0.99 & 1811 & \\
\hline 80SF-3 & 28 & $37 / 8$ & $315 / 16$ & $71 / 2$ & 15.26 & 24000 & 1573 & 1.94 & 0.98 & 1545 & \\
\hline
\end{tabular}

* Height to thickness correction factor from Table 1 of ASTM C 1314.

Values have been linearly interpolated as necessary

Performance of No Vibration/No Admixture Masonry Grout Containing High Replacement of Portland Cement with Fly Ash and Ground Granulated Blast Furnace Slag 
Appendix B 83

\title{
B.4 Compression Test Specimens: 42 Days of Curing
}

Testing Lab:

\author{
CAED Concrete Lab
}

ASTM C 1019 Test Report:

Standard Test Method for Sampling and Testing Grout

Project Identification: Compression Experiment, Grout Compression Tests

Grout Information

Grout Type:

Date Grouted:

100C, 50F, 60F, 70F, 60SF, 70SF, 80SF

Date Tested:

Grout Slumps:

$8 / 8 / 2012$

9/19/2012

Curing Time:

42 Days

Method of Consolidation:

See Appendix A

50F, 60F, 70F, 60SF, 70SF, 80SF:Self-Consolidating

100C: Mechanical Vibration

Tested Grout Properties:

\begin{tabular}{|c|c|c|c|c|c|c|c|c|c|c|c|}
\hline \multirow{2}{*}{$\begin{array}{l}\text { Grout } \\
\text { Sample }\end{array}$} & \multirow{2}{*}{$\begin{array}{l}\text { Age at } \\
\text { Test } \\
\text { (Days) }\end{array}$} & \multicolumn{2}{|c|}{$\begin{array}{l}\text { Cross Section } \\
\text { Dimensions }\end{array}$} & \multirow{2}{*}{$\begin{array}{l}\text { Avg. } \\
\text { Height } \\
\text { (in.) }\end{array}$} & \multirow{2}{*}{$\begin{array}{l}\text { Net } \\
\text { Area } \\
\left(\mathrm{in}^{2}\right)\end{array}$} & \multirow{2}{*}{$\begin{array}{l}\text { Max } \\
\text { Load } \\
\text { (lb.) }\end{array}$} & \multirow{2}{*}{$\begin{array}{c}\text { Net } \\
\text { Comp. } \\
\text { Strength } \\
\text { (psi) }\end{array}$} & \multirow{2}{*}{$\begin{array}{c}\mathrm{h} / \mathrm{t} \\
\text { Ratio }\end{array}$} & \multirow{2}{*}{$\begin{array}{l}\mathrm{h} / \mathrm{t} \\
\mathrm{CF} F^{*}\end{array}$} & \multirow{2}{*}{$\begin{array}{l}\text { Corrected } \\
\text { Net } \\
\text { Strength } \\
\text { (psi) }\end{array}$} & \multirow{2}{*}{$\begin{array}{c}\text { Avg. } \\
\text { Corrected } \\
\text { Net } \\
\text { Strength, } \\
f_{g} \text { (psi) }\end{array}$} \\
\hline & & $\begin{array}{l}\text { Avg. } \\
\text { Width } \\
\text { (in.) }\end{array}$ & $\begin{array}{l}\text { Avg. } \\
\text { Length } \\
\text { (in.) }\end{array}$ & & & & & & & & \\
\hline $100 \mathrm{C}-1$ & 42 & $37 / 8$ & 4 & $71 / 2$ & 15.50 & 45000 & 2903 & 1.94 & 0.98 & 2851 & \multirow{3}{*}{2995} \\
\hline $100 \mathrm{C}-2$ & 42 & $313 / 16$ & $37 / 8$ & $71 / 2$ & 14.77 & 45000 & 3046 & 1.97 & 0.99 & 3018 & \\
\hline $100 \mathrm{C}-3$ & 42 & $3 \quad 3 / 4$ & $315 / 16$ & $71 / 2$ & 14.77 & 46000 & 3115 & 2.00 & 1.00 & 3115 & \\
\hline $50 \mathrm{~F}-1$ & 42 & $313 / 16$ & $37 / 8$ & $77 / 16$ & 14.77 & 20000 & 1354 & 1.95 & 0.99 & 1335 & \multirow{3}{*}{1395} \\
\hline $50 \mathrm{~F}-2$ & 42 & $37 / 8$ & $315 / 16$ & $7 \quad 1 / 2$ & 15.26 & 21000 & 1376 & 1.94 & 0.98 & 1351 & \\
\hline $50 \mathrm{~F}-3$ & 42 & $37 / 8$ & $37 / 8$ & $77 / 16$ & 15.02 & 23000 & 1532 & 1.92 & 0.98 & 1497 & \\
\hline $60 \mathrm{~F}-1$ & 42 & $311 / 16$ & $37 / 8$ & $\begin{array}{ll}7 & 1 / 2 \\
\end{array}$ & 14.29 & 12000 & 840 & 2.03 & 1.00 & 842 & \multirow{3}{*}{807} \\
\hline $60 \mathrm{~F}-2$ & 42 & $33 / 4$ & $33 / 4$ & $77 / 16$ & 14.06 & 11000 & 782 & 1.98 & 1.00 & 779 & \\
\hline $60 \mathrm{~F}-3$ & 42 & $313 / 16$ & $37 / 8$ & $77 / 16$ & 14.77 & 12000 & 812 & 1.95 & 0.99 & 801 & \\
\hline $70 \mathrm{~F}-1$ & 42 & $311 / 16$ & $3 \quad 3 / 4$ & $\begin{array}{ll}7 & 1 / 2 \\
\end{array}$ & 13.83 & 6000 & 434 & 2.03 & 1.00 & 435 & \multirow{3}{*}{468} \\
\hline $70 \mathrm{~F}-2$ & 42 & $35 / 8$ & $311 / 16$ & $77 / 16$ & 13.37 & 6000 & 449 & 2.05 & 1.00 & 451 & \\
\hline $70 \mathrm{~F}-3$ & 42 & $35 / 8$ & $3 \quad 3 / 4$ & $77 / 16$ & 13.59 & 7000 & 515 & 2.05 & 1.00 & 517 & \\
\hline 60SF-1 & 42 & $313 / 16$ & $37 / 8$ & $71 / 2$ & 14.77 & 31000 & 2098 & 1.97 & 0.99 & 2079 & \multirow{3}{*}{2023} \\
\hline 60 SF-2 & 42 & $37 / 8$ & $315 / 16$ & $\begin{array}{ll}7 & 1 / 2 \\
\end{array}$ & 15.26 & 31000 & 2032 & 1.94 & 0.98 & 1995 & \\
\hline 60SF-3 & 42 & $33 / 4$ & $37 / 8$ & $\begin{array}{ll}7 & 1 / 2 \\
\end{array}$ & 14.53 & 29000 & 1996 & 2.00 & 1.00 & 1996 & \\
\hline 70SF-1 & 42 & $313 / 16$ & $313 / 16$ & $\begin{array}{ll}7 & 1 / 2 \\
\end{array}$ & 14.54 & 32000 & 2202 & 1.97 & 0.99 & 2181 & \multirow{3}{*}{2137} \\
\hline 70SF-2 & 42 & $37 / 8$ & $37 / 8$ & $77 / 16$ & 15.02 & 32000 & 2131 & 1.92 & 0.98 & 2083 & \\
\hline 70SF-3 & 42 & $313 / 16$ & $37 / 8$ & $71 / 2$ & 14.77 & 32000 & 2166 & 1.97 & 0.99 & 2146 & \\
\hline 80SF-1 & 42 & $37 / 8$ & $315 / 16$ & $\begin{array}{ll}7 & 1 / 2 \\
\end{array}$ & 15.26 & 28000 & 1835 & 1.94 & 0.98 & 1802 & \multirow{3}{*}{1899} \\
\hline 80SF-2 & 42 & $313 / 16$ & $37 / 8$ & $7 \quad 1 / 2$ & 14.77 & 28000 & 1895 & 1.97 & 0.99 & 1878 & \\
\hline 80SF-3 & 42 & $37 / 8$ & $37 / 8$ & $77 / 16$ & 15.02 & 31000 & 2065 & 1.92 & 0.98 & 2018 & \\
\hline
\end{tabular}

* Height to thickness correction factor from Table 1 of ASTM C 1314.

Values have been linearly interpolated as necessary

Performance of No Vibration/No Admixture Masonry Grout Containing High Replacement of Portland Cement with Fly Ash and Ground Granulated Blast Furnace Slag 


\title{
B.5 Compression Test Specimens: 56 Days of Curing
}

Testing Lab:

\author{
CAED Concrete Lab
}

ASTM C 1019 Test Report:

Standard Test Method for Sampling and Testing Grout

Project Identification: Compression Experiment, Grout Compression Tests

Grout Information

Grout Type:

Date Grouted:

100C, 50F, 60F, 70F, 60SF, 70SF, 80SF

Date Tested:

Grout Slumps:

$8 / 8 / 2012$

\begin{tabular}{lll}
$\frac{10 / 3 / 2012}{\text { See Appendix A }}$ & Curing Time: & 56 \\
\hline 50F, 60F, 70F, 60SF, 70SF, 80SF:Self-Consolidating & \\
\hline 100C: Mechanical Vibration &
\end{tabular}

Tested Grout Properties:

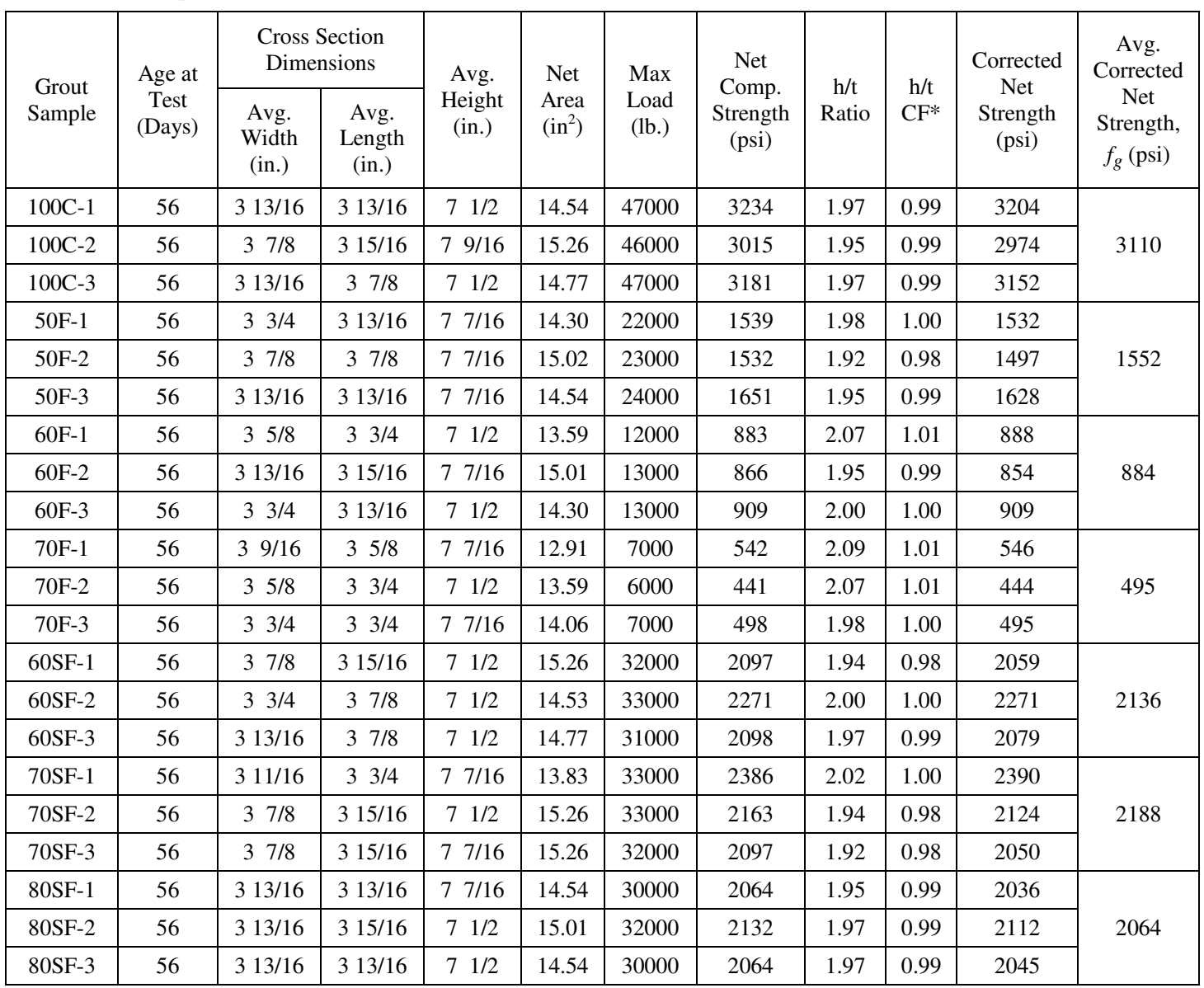

* Height to thickness correction factor from Table 1 of ASTM C 1314.

Values have been linearly interpolated as necessary

Performance of No Vibration/No Admixture Masonry Grout Containing High Replacement of Portland Cement with Fly Ash and Ground Granulated Blast Furnace Slag 


\title{
B.6 Compression Test Specimens: 130 Days of Curing
}

Testing Lab:

\author{
CAED Concrete Lab
}

ASTM C 1019 Test Report:

Standard Test Method for Sampling and Testing Grout

Project Identification: Compression Experiment, Grout Compression Tests

Grout Information

Grout Type:

Date Grouted:

100C, 50F, 60F, 70F, 60SF, 70SF, 80SF

Date Tested:

Grout Slumps:

$8 / 8 / 2012$

\begin{tabular}{lll}
$\frac{12 / 16 / 2012}{\text { See Appendix A }}$ & Curing Time: 130 \\
\hline 50F, 60F, 70F, 60SF, 70SF, 80SF:Self-Consolidating & \\
\hline 100C: Mechanical Vibration &
\end{tabular}

Tested Grout Properties:

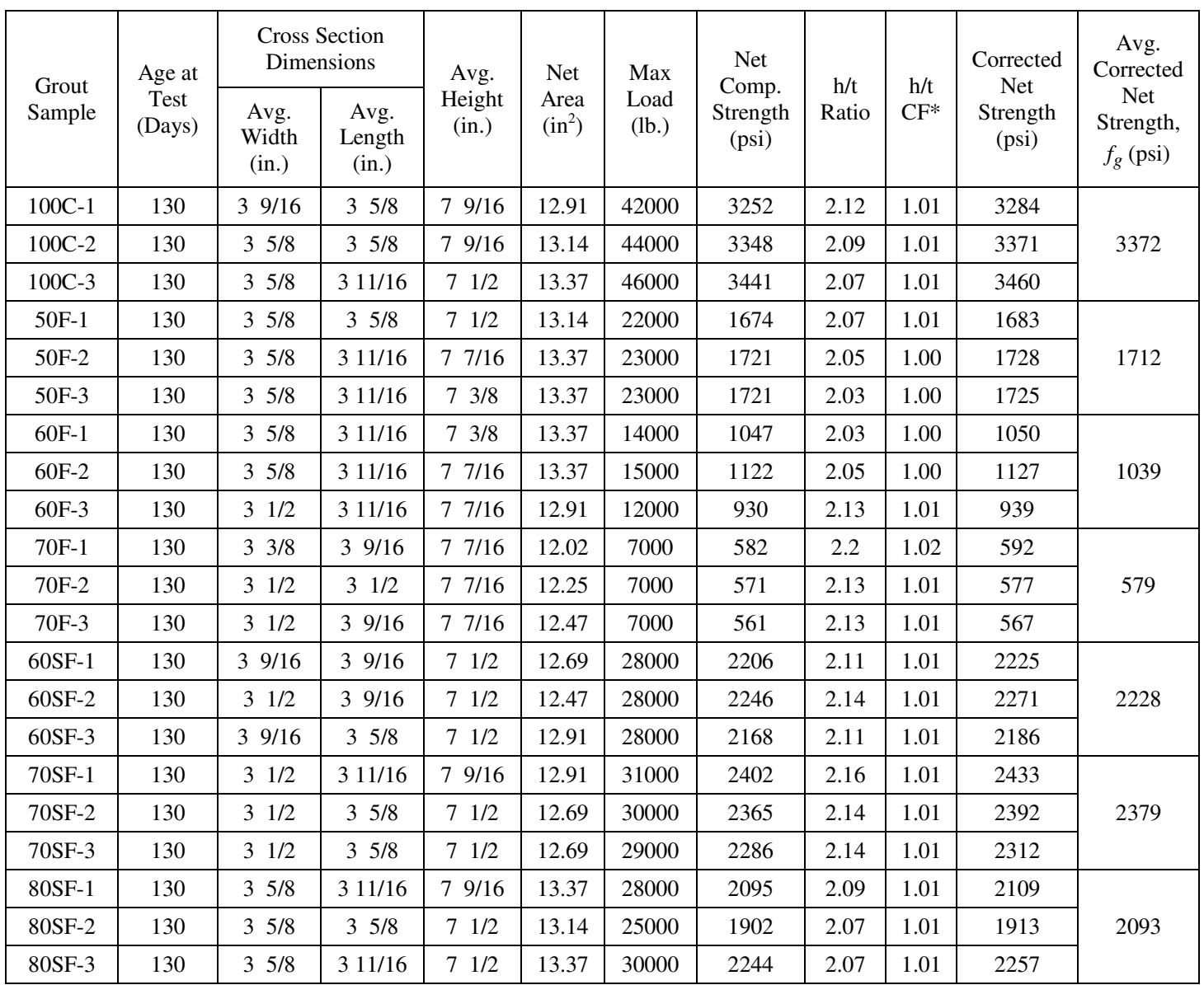

* Height to thickness correction factor from Table 1 of ASTM C 1314.

Values have been linearly interpolated as necessary

Performance of No Vibration/No Admixture Masonry Grout Containing High Replacement of Portland Cement with Fly Ash and Ground Granulated Blast Furnace Slag 


\title{
Appendix C - Grout Compressive Strengths from The Wall Experiment
}

\section{C.1 Wall Compression Test Specimens: Wall 1}

\author{
ASTM C 1019 Test Report: \\ Standard Test Method for Sampling and Testing Grout \\ Testing Lab: $\quad$ CAED Concrete Lab \\ Project Identification: Wall Experiment, Grout Compression Tests
}

Grout Information:

Grout Columns ID:

Grout Type:

Date Grouted:

Date Tested:

Grout Slumps:

Method of Consolidation:

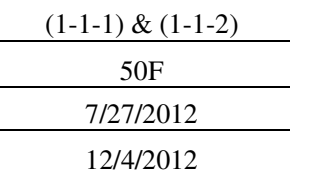

See Appendix A.6

Self-Consolidating
Curing Time: 130 Days

Tested Grout Properties:

\begin{tabular}{|c|c|c|c|c|c|c|c|c|c|c|}
\hline \multirow{2}{*}{$\begin{array}{l}\text { Grout } \\
\text { Sample }\end{array}$} & \multirow{2}{*}{$\begin{array}{l}\text { Age at } \\
\text { Test } \\
\text { (Days) }\end{array}$} & \multicolumn{2}{|c|}{$\begin{array}{c}\text { Cross Section } \\
\text { Dimensions } \\
\end{array}$} & \multirow{2}{*}{$\begin{array}{l}\text { Avg. } \\
\text { Height } \\
\text { (in.) }\end{array}$} & \multirow{2}{*}{$\begin{array}{l}\text { Net } \\
\text { Area } \\
\left(\text { in. }^{2}\right)\end{array}$} & \multirow{2}{*}{$\begin{array}{c}\text { Max } \\
\text { Load } \\
\text { (lb.) }\end{array}$} & \multirow{2}{*}{$\begin{array}{c}\text { Net } \\
\text { Comp. } \\
\text { Strength } \\
\text { (psi) }\end{array}$} & \multirow[b]{2}{*}{$\begin{array}{c}\mathrm{h} / \mathrm{t} \\
\text { Ratio }\end{array}$} & \multirow[b]{2}{*}{$\begin{array}{l}\mathrm{h} / \mathrm{t} \\
\mathrm{CF}\end{array}$} & \multirow{2}{*}{$\begin{array}{c}\text { Corrected } \\
\text { Net } \\
\text { Strength, } \\
f_{g}(\mathrm{psi})\end{array}$} \\
\hline & & $\begin{array}{l}\text { Avg. } \\
\text { Width } \\
\text { (in.) }\end{array}$ & $\begin{array}{l}\text { Avg. } \\
\text { Length } \\
\text { (in.) }\end{array}$ & & & & & & & \\
\hline $1-1-1-1$ & 130 & $311 / 16$ & $3 \quad 3 / 4$ & $75 / 8$ & 13.83 & 24000 & 1736 & 2.07 & 1.01 & 1745 \\
\hline $1-1-1-2$ & 130 & $33 / 4$ & $33 / 4$ & $73 / 4$ & 14.06 & 24000 & 1707 & 2.07 & 1.01 & 1716 \\
\hline $1-1-1-3$ & 130 & $311 / 16$ & $33 / 4$ & $711 / 16$ & 13.83 & 22000 & 1591 & 2.08 & 1.01 & 1602 \\
\hline $1-1-1-4$ & 130 & $3 \quad 3 / 4$ & $\begin{array}{ll}3 / 4 \\
\end{array}$ & $715 / 16$ & 14.06 & 21000 & 1493 & 2.12 & 1.01 & 1507 \\
\hline $1-1-1-5$ & 130 & $35 / 8$ & $3 \quad 3 / 4$ & $75 / 8$ & 13.59 & 21000 & 1545 & 2.10 & 1.01 & 1558 \\
\hline $1-1-1-6$ & 130 & $311 / 16$ & $311 / 16$ & $711 / 16$ & 13.60 & 23000 & 1691 & 2.08 & 1.01 & 1703 \\
\hline $1-1-2-1$ & 130 & $311 / 16$ & $311 / 16$ & $73 / 4$ & 13.60 & 14000 & 1030 & 2.10 & 1.01 & 1038 \\
\hline $1-1-2-2$ & 130 & $33 / 4$ & $33 / 4$ & $73 / 4$ & 14.06 & 22000 & 1564 & 2.07 & 1.01 & 1573 \\
\hline $1-1-2-3$ & 130 & $313 / 16$ & $313 / 16$ & $75 / 8$ & 14.54 & 23000 & 1582 & 2.00 & 1.00 & 1582 \\
\hline $1-1-2-4$ & 130 & $33 / 4$ & $33 / 4$ & $7 \quad 3 / 4$ & 14.06 & 20000 & 1422 & 2.07 & 1.01 & 1430 \\
\hline $1-1-2-5$ & 130 & $35 / 8$ & $3 \quad 3 / 4$ & $7 \quad 3 / 4$ & 13.59 & 20000 & 1471 & 2.14 & 1.01 & 1487 \\
\hline $1-1-2-6$ & 130 & $39 / 16$ & $33 / 4$ & $75 / 8$ & 13.36 & 16000 & 1198 & 2.14 & 1.01 & 1211 \\
\hline & & & & & & & & $\mathrm{Av}$ & & 1513 \\
\hline
\end{tabular}

* Height to thickness correction factor from Table 1 of ASTM C 1314. Values have been linearly interpolated as necessary

Performance of No Vibration/No Admixture Masonry Grout Containing High Replacement of Portland Cement with Fly Ash and Ground Granulated Blast Furnace Slag 


\section{C.1 Wall Compression Test Specimens: Wall 1}

ASTM C 1019 Test Report:

Standard Test Method for Sampling and Testing Grout

Testing Lab: $\quad$ CAED Concrete Lab

Project Identification: Wall Experiment, Grout Compression Tests

Grout Information:

Grout Columns ID:

Grout Type:

Date Grouted:

Date Tested:

Grout Slumps:

Method of Consolidation:

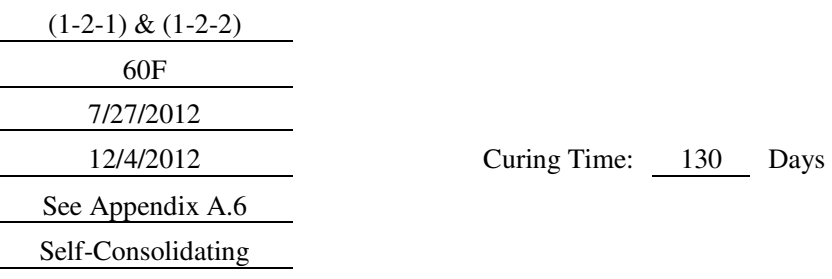

Tested Grout Properties:

\begin{tabular}{|c|c|c|c|c|c|c|c|c|c|c|}
\hline \multirow{2}{*}{$\begin{array}{l}\text { Grout } \\
\text { Sample }\end{array}$} & \multirow{2}{*}{$\begin{array}{l}\text { Age at } \\
\text { Test } \\
\text { (Days) }\end{array}$} & \multicolumn{2}{|c|}{$\begin{array}{c}\text { Cross Section } \\
\text { Dimensions }\end{array}$} & \multirow{2}{*}{$\begin{array}{l}\text { Avg. } \\
\text { Height } \\
\text { (in.) }\end{array}$} & \multirow{2}{*}{$\begin{array}{l}\mathrm{Net} \\
\text { Area } \\
\text { (in. }{ }^{2} \text { ) }\end{array}$} & \multirow{2}{*}{$\begin{array}{l}\text { Max } \\
\text { Load } \\
\text { (lb.) }\end{array}$} & \multirow{2}{*}{$\begin{array}{c}\text { Net } \\
\text { Comp. } \\
\text { Strength } \\
\text { (psi) }\end{array}$} & \multirow[b]{2}{*}{$\begin{array}{l}\mathrm{h} / \mathrm{t} \\
\text { Ratio }\end{array}$} & \multirow[b]{2}{*}{$\begin{array}{l}\mathrm{h} / \mathrm{t} \\
\mathrm{CF}\end{array}$} & \multirow{2}{*}{$\begin{array}{c}\text { Corrected } \\
\text { Net } \\
\text { Strength, } \\
f_{g}(\mathrm{psi})\end{array}$} \\
\hline & & $\begin{array}{l}\text { Avg. } \\
\text { Width } \\
\text { (in.) }\end{array}$ & $\begin{array}{l}\text { Avg. } \\
\text { Length } \\
\text { (in.) }\end{array}$ & & & & & & & \\
\hline $1-2-1-1$ & 130 & $35 / 8$ & $311 / 16$ & $713 / 16$ & 13.37 & 15000 & 1122 & 2.16 & 1.01 & 1136 \\
\hline $1-2-1-2$ & 130 & $33 / 4$ & $33 / 4$ & $79 / 16$ & 14.06 & 17000 & 1209 & 2.02 & 1.00 & 1211 \\
\hline $1-2-1-3$ & 130 & $33 / 4$ & $33 / 4$ & $711 / 16$ & 14.06 & 17000 & 1209 & 2.05 & 1.00 & 1214 \\
\hline 1-2-1-4 & 130 & $35 / 8$ & $33 / 4$ & $711 / 16$ & 13.59 & 16000 & 1177 & 2.12 & 1.01 & 1188 \\
\hline $1-2-1-5$ & 130 & $33 / 4$ & $33 / 4$ & $73 / 4$ & 14.06 & 16000 & 1138 & 2.07 & 1.01 & 1144 \\
\hline $1-2-1-6$ & 130 & $311 / 16$ & $33 / 4$ & $73 / 4$ & 13.83 & 15000 & 1085 & 2.10 & 1.01 & 1094 \\
\hline $1-2-2-1$ & 130 & $35 / 8$ & $33 / 4$ & $713 / 16$ & 13.59 & 13000 & 956 & 2.16 & 1.01 & 968 \\
\hline $1-2-2-2$ & 130 & $313 / 16$ & $313 / 16$ & $79 / 16$ & 14.54 & 16000 & 1101 & 1.98 & 1.00 & 1096 \\
\hline $1-2-2-3$ & 130 & $33 / 4$ & $33 / 4$ & $711 / 16$ & 14.06 & 18000 & 1280 & 2.05 & 1.00 & 1285 \\
\hline $1-2-2-4$ & 130 & $35 / 8$ & $35 / 8$ & $73 / 4$ & 13.14 & 13000 & 989 & 2.14 & 1.01 & 1000 \\
\hline $1-2-2-5$ & 130 & $33 / 4$ & $33 / 4$ & $\begin{array}{ll}7 & 1 / 2 \\
\end{array}$ & 14.06 & 17000 & 1209 & 2.00 & 1.00 & 1209 \\
\hline $1-2-2-6$ & 130 & $33 / 4$ & $33 / 4$ & $713 / 16$ & 14.06 & 15000 & 1067 & 2.08 & 1.01 & 1074 \\
\hline
\end{tabular}

* Height to thickness correction factor from Table 1 of ASTM C 1314. Values have been linearly interpolated as necessary

Performance of No Vibration/No Admixture Masonry Grout Containing High Replacement of Portland Cement with Fly Ash and Ground Granulated Blast Furnace Slag 


\section{C.1 Wall Compression Test Specimens: Wall 1}

ASTM C 1019 Test Report:

Standard Test Method for Sampling and Testing Grout

Testing Lab: $\quad$ CAED Concrete Lab

Project Identification: Wall Experiment, Grout Compression Tests

Grout Information:

Grout Columns ID:

Grout Type:

Date Grouted:

Date Tested:

Grout Slumps:

Method of Consolidation:

\begin{tabular}{c}
$(1-3-1) \&(1-3-2)$ \\
\hline $70 \mathrm{~F}$ \\
\hline $7 / 27 / 2012$ \\
\hline $12 / 4 / 2012$ \\
\hline See Appendix A.6 \\
\hline Self-Consolidating \\
\hline
\end{tabular}

Curing Time: 130 Days

Tested Grout Properties:

\begin{tabular}{|c|c|c|c|c|c|c|c|c|c|c|}
\hline \multirow{2}{*}{$\begin{array}{l}\text { Grout } \\
\text { Sample }\end{array}$} & \multirow{2}{*}{$\begin{array}{l}\text { Age at } \\
\text { Test } \\
\text { (Days) }\end{array}$} & \multicolumn{2}{|c|}{$\begin{array}{c}\text { Cross Section } \\
\text { Dimensions }\end{array}$} & \multirow{2}{*}{$\begin{array}{l}\text { Avg. } \\
\text { Height } \\
\text { (in.) }\end{array}$} & \multirow{2}{*}{$\begin{array}{l}\text { Net } \\
\text { Area } \\
\left(\text { in. }^{2}\right)\end{array}$} & \multirow{2}{*}{$\begin{array}{l}\text { Max } \\
\text { Load } \\
\text { (lb.) }\end{array}$} & \multirow{2}{*}{$\begin{array}{c}\text { Net } \\
\text { Comp. } \\
\text { Strength } \\
\text { (psi) }\end{array}$} & \multirow[b]{2}{*}{$\begin{array}{l}\mathrm{h} / \mathrm{t} \\
\text { Ratio }\end{array}$} & \multirow[b]{2}{*}{$\begin{array}{l}\mathrm{h} / \mathrm{t} \\
\mathrm{CF}\end{array}$} & \multirow{2}{*}{$\begin{array}{c}\text { Corrected } \\
\text { Net } \\
\text { Strength, } \\
f_{g}(\mathrm{psi})\end{array}$} \\
\hline & & $\begin{array}{l}\text { Avg. } \\
\text { Width } \\
\text { (in.) }\end{array}$ & $\begin{array}{l}\text { Avg. } \\
\text { Length } \\
\text { (in.) }\end{array}$ & & & & & & & \\
\hline $1-3-1-1$ & 130 & $311 / 16$ & 3 3/4 & $77 / 8$ & 13.83 & 11000 & 795 & 2.14 & 1.01 & 804 \\
\hline $1-3-1-2$ & 130 & $311 / 16$ & $33 / 4$ & $75 / 8$ & 13.83 & 12000 & 868 & 2.07 & 1.01 & 873 \\
\hline $1-3-1-3$ & 130 & $311 / 16$ & $33 / 4$ & $75 / 8$ & 13.83 & 10000 & 723 & 2.07 & 1.01 & 727 \\
\hline $1-3-1-4$ & 130 & $35 / 8$ & $35 / 8$ & $73 / 4$ & 13.14 & 10000 & 761 & 2.14 & 1.01 & 769 \\
\hline $1-3-1-5$ & 130 & $311 / 16$ & $33 / 4$ & $75 / 8$ & 13.83 & 11000 & 795 & 2.07 & 1.01 & 800 \\
\hline $1-3-1-6$ & 130 & $35 / 8$ & $3 \quad 3 / 4$ & 7 13/16 & 13.59 & 12000 & 883 & 2.16 & 1.01 & 894 \\
\hline $1-3-2-1$ & 130 & $33 / 16$ & $31 / 4$ & $71 / 4$ & 10.36 & 7000 & 676 & 2.27 & 1.02 & 691 \\
\hline $1-3-2-2$ & 130 & $35 / 8$ & $33 / 4$ & $73 / 4$ & 13.59 & 13000 & 956 & 2.14 & 1.01 & 967 \\
\hline $1-3-2-3$ & 130 & $311 / 16$ & $33 / 4$ & $711 / 16$ & 13.83 & 13000 & 940 & 2.08 & 1.01 & 946 \\
\hline $1-3-2-4$ & 130 & $311 / 16$ & $33 / 4$ & $73 / 4$ & 13.83 & 11000 & 795 & 2.10 & 1.01 & 802 \\
\hline $1-3-2-5$ & 130 & $35 / 8$ & $33 / 4$ & $\begin{array}{ll}7 & 1 / 2 \\
\end{array}$ & 13.59 & 11000 & 809 & 2.07 & 1.01 & 814 \\
\hline $1-3-2-6$ & 130 & $39 / 16$ & $33 / 4$ & $77 / 8$ & 13.36 & 12000 & 898 & 2.21 & 1.02 & 913 \\
\hline
\end{tabular}

* Height to thickness correction factor from Table 1 of ASTM C 1314. Values have been linearly interpolated as necessary

Performance of No Vibration/No Admixture Masonry Grout Containing High Replacement of Portland Cement with Fly Ash and Ground Granulated Blast Furnace Slag 


\section{C.2 Wall Compression Test Specimens: Wall 2}

ASTM C 1019 Test Report:

Standard Test Method for Sampling and Testing Grout

Testing Lab: $\quad$ CAED Concrete Lab

Project Identification: Wall Experiment, Grout Compression Tests

Grout Information:

Grout Columns ID:

Grout Type:

Date Grouted:

Date Tested:

Grout Slumps:

Method of Consolidation:

\begin{tabular}{c}
$\frac{(2-1-1) \&(2-1-2)}{60 \mathrm{SF}}$ \\
\hline $7 / 29 / 2012$ \\
\hline $12 / 6 / 2012$ \\
\hline See Appendix A.6 \\
\hline Self-Consolidating \\
\hline
\end{tabular}

Curing Time: 130 Days

Tested Grout Properties:

\begin{tabular}{|c|c|c|c|c|c|c|c|c|c|c|}
\hline \multirow{2}{*}{$\begin{array}{l}\text { Grout } \\
\text { Sample }\end{array}$} & \multirow{2}{*}{$\begin{array}{l}\text { Age at } \\
\text { Test } \\
\text { (Days) }\end{array}$} & \multicolumn{2}{|c|}{$\begin{array}{c}\text { Cross Section } \\
\text { Dimensions } \\
\end{array}$} & \multirow{2}{*}{$\begin{array}{l}\text { Avg. } \\
\text { Height } \\
\text { (in.) }\end{array}$} & \multirow{2}{*}{$\begin{array}{l}\text { Net } \\
\text { Area } \\
\text { (in. }{ }^{2} \text { ) }\end{array}$} & \multirow{2}{*}{$\begin{array}{l}\text { Max } \\
\text { Load } \\
\text { (lb.) }\end{array}$} & \multirow{2}{*}{$\begin{array}{c}\text { Net } \\
\text { Comp. } \\
\text { Strength } \\
\text { (psi) }\end{array}$} & \multirow{2}{*}{$\begin{array}{c}\mathrm{h} / \mathrm{t} \\
\text { Ratio }\end{array}$} & \multirow[b]{2}{*}{$\begin{array}{l}\mathrm{h} / \mathrm{t} \\
\mathrm{CF} *\end{array}$} & \multirow{2}{*}{$\begin{array}{l}\text { Corrected } \\
\text { Net } \\
\text { Strength, } \\
f_{g}(\mathrm{psi})\end{array}$} \\
\hline & & $\begin{array}{l}\text { Avg. } \\
\text { Width } \\
\text { (in.) }\end{array}$ & $\begin{array}{l}\text { Avg. } \\
\text { Length } \\
\text { (in.) }\end{array}$ & & & & & & & \\
\hline $2-1-1-1$ & 130 & $311 / 16$ & $33 / 4$ & $73 / 4$ & 13.83 & 23000 & 1663 & 2.10 & 1.01 & 1677 \\
\hline $2-1-1-2$ & 130 & $311 / 16$ & $313 / 16$ & 7 13/16 & 14.06 & 33000 & 2347 & 2.12 & 1.01 & 2370 \\
\hline $2-1-1-3$ & 130 & $33 / 4$ & $33 / 4$ & $75 / 8$ & 14.06 & 32000 & 2276 & 2.03 & 1.00 & 2282 \\
\hline $2-1-1-4$ & 130 & $33 / 4$ & $33 / 4$ & $711 / 16$ & 14.06 & 31000 & 2204 & 2.05 & 1.00 & 2213 \\
\hline $2-1-1-5$ & 130 & $33 / 4$ & $37 / 8$ & $75 / 8$ & 14.53 & 26000 & 1789 & 2.03 & 1.00 & 1794 \\
\hline $2-1-1-6$ & 130 & $33 / 4$ & $33 / 4$ & $77 / 8$ & 14.06 & 25000 & 1778 & 2.10 & 1.01 & 1792 \\
\hline $2-1-2-1$ & 130 & $33 / 4$ & $33 / 4$ & $73 / 4$ & 14.06 & 28000 & 1991 & 2.07 & 1.01 & 2002 \\
\hline $2-1-2-2$ & 130 & $313 / 16$ & $37 / 8$ & $73 / 4$ & 14.77 & 38000 & 2572 & 2.03 & 1.00 & 2579 \\
\hline $2-1-2-3$ & 130 & $33 / 4$ & $313 / 16$ & $711 / 16$ & 14.30 & 35000 & 2448 & 2.05 & 1.00 & 2458 \\
\hline $2-1-2-4$ & 130 & $33 / 4$ & $33 / 4$ & $73 / 4$ & 14.06 & 36000 & 2560 & 2.07 & 1.01 & 2574 \\
\hline $2-1-2-5$ & 130 & $33 / 4$ & $313 / 16$ & $711 / 16$ & 14.30 & 36000 & 2518 & 2.05 & 1.00 & 2528 \\
\hline $2-1-2-6$ & 130 & $35 / 8$ & $311 / 16$ & $77 / 8$ & 13.37 & 36000 & 2693 & 2.17 & 1.01 & 2730 \\
\hline & & & & & & & & Av & & 2250 \\
\hline
\end{tabular}

* Height to thickness correction factor from Table 1 of ASTM C 1314. Values have been linearly interpolated as necessary 


\section{C.2 Wall Compression Test Specimens: Wall 2}

ASTM C 1019 Test Report:

Standard Test Method for Sampling and Testing Grout

Testing Lab: $\quad$ CAED Concrete Lab

Project Identification: Wall Experiment, Grout Compression Tests

Grout Information:

Grout Columns ID:

Grout Type:

Date Grouted:

Date Tested:

Grout Slumps:

Method of Consolidation:

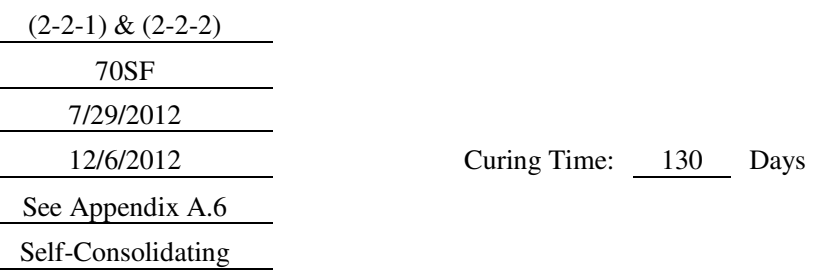

Tested Grout Properties:

\begin{tabular}{|c|c|c|c|c|c|c|c|c|c|c|}
\hline \multirow[b]{2}{*}{$\begin{array}{l}\text { Grout } \\
\text { Sample }\end{array}$} & \multirow{2}{*}{$\begin{array}{l}\text { Age at } \\
\text { Test } \\
\text { (Days) }\end{array}$} & \multicolumn{2}{|c|}{$\begin{array}{c}\text { Cross Section } \\
\text { Dimensions }\end{array}$} & \multirow{2}{*}{$\begin{array}{l}\text { Avg. } \\
\text { Height } \\
\text { (in.) }\end{array}$} & \multirow{2}{*}{$\begin{array}{l}\text { Net } \\
\text { Area } \\
\text { (in. }{ }^{2} \text { ) }\end{array}$} & \multirow{2}{*}{$\begin{array}{l}\text { Max } \\
\text { Load } \\
\text { (lb.) }\end{array}$} & \multirow{2}{*}{$\begin{array}{c}\text { Net } \\
\text { Comp. } \\
\text { Strength } \\
\text { (psi) }\end{array}$} & \multirow{2}{*}{$\begin{array}{l}\mathrm{h} / \mathrm{t} \\
\text { Ratio }\end{array}$} & \multirow{2}{*}{$\begin{array}{l}\mathrm{h} / \mathrm{t} \\
\mathrm{CF} *\end{array}$} & \multirow{2}{*}{$\begin{array}{c}\text { Corrected } \\
\text { Net } \\
\text { Strength, } \\
f_{g}(\mathrm{psi})\end{array}$} \\
\hline & & $\begin{array}{l}\text { Avg. } \\
\text { Width } \\
\text { (in.) }\end{array}$ & $\begin{array}{l}\text { Avg. } \\
\text { Length } \\
\text { (in.) }\end{array}$ & & & & & & & \\
\hline $2-2-1-1$ & 130 & $311 / 16$ & $33 / 4$ & $73 / 4$ & 13.83 & 25000 & 1808 & 2.10 & 1.01 & 1823 \\
\hline $2-2-1-2$ & 130 & $\begin{array}{ll}3 & 3 / 4 \\
\end{array}$ & $37 / 8$ & $711 / 16$ & 14.53 & 30000 & 2065 & 2.05 & 1.00 & 2073 \\
\hline $2-2-1-3$ & 130 & $\begin{array}{ll}3 & 3 / 4 \\
\end{array}$ & $33 / 4$ & $73 / 4$ & 14.06 & 28000 & 1991 & 2.07 & 1.01 & 2002 \\
\hline $2-2-1-4$ & 130 & $33 / 4$ & $37 / 8$ & $73 / 4$ & 14.53 & 31000 & 2133 & 2.07 & 1.01 & 2145 \\
\hline $2-2-1-5$ & 130 & $311 / 16$ & $33 / 4$ & $75 / 8$ & 13.83 & 27000 & 1953 & 2.07 & 1.01 & 1963 \\
\hline $2-2-1-6$ & 130 & $\begin{array}{ll}3 & 3 / 4 \\
\end{array}$ & $313 / 16$ & $77 / 8$ & 14.30 & 26000 & 1819 & 2.10 & 1.01 & 1833 \\
\hline $2-2-2-1$ & 130 & $33 / 4$ & $33 / 4$ & $713 / 16$ & 14.06 & 28000 & 1991 & 2.08 & 1.01 & 2004 \\
\hline $2-2-2-2$ & 130 & $313 / 16$ & $315 / 16$ & $711 / 16$ & 15.01 & 28000 & 1865 & 2.02 & 1.00 & 1868 \\
\hline $2-2-2-3$ & 130 & $33 / 4$ & $313 / 16$ & $73 / 4$ & 14.30 & 28000 & 1958 & 2.07 & 1.01 & 1969 \\
\hline $2-2-2-4$ & 130 & $311 / 16$ & $313 / 16$ & $73 / 4$ & 14.06 & 27000 & 1921 & 2.10 & 1.01 & 1936 \\
\hline $2-2-2-5$ & 130 & $3 \quad 3 / 4$ & $313 / 16$ & $79 / 16$ & 14.30 & 27000 & 1889 & 2.02 & 1.00 & 1891 \\
\hline $2-2-2-6$ & 130 & $311 / 16$ & $33 / 4$ & 7 13/16 & 13.83 & 28000 & 2025 & 2.12 & 1.01 & 2044 \\
\hline & & & & & & & & Ave & ge: & 1963 \\
\hline
\end{tabular}

* Height to thickness correction factor from Table 1 of ASTM C 1314. Values have been linearly interpolated as necessary

Performance of No Vibration/No Admixture Masonry Grout Containing High Replacement of Portland Cement with Fly Ash and Ground Granulated Blast Furnace Slag 


\section{C.2 Wall Compression Test Specimens: Wall 2}

ASTM C 1019 Test Report:

Standard Test Method for Sampling and Testing Grout

Testing Lab: $\quad$ CAED Concrete Lab

Project Identification: Wall Experiment, Grout Compression Tests

Grout Information:

Grout Columns ID:

Grout Type:

Date Grouted:

Date Tested:

Grout Slumps:

Method of Consolidation:

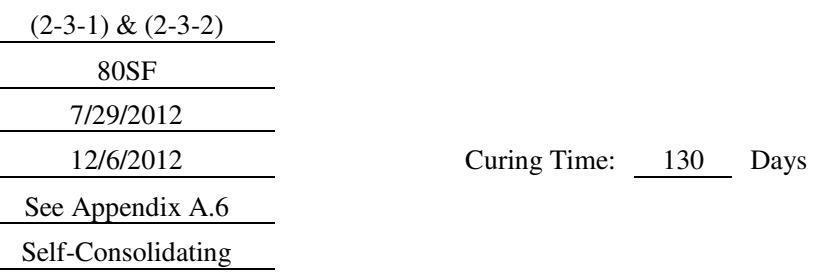

Tested Grout Properties:

\begin{tabular}{|c|c|c|c|c|c|c|c|c|c|c|}
\hline \multirow[b]{2}{*}{$\begin{array}{l}\text { Grout } \\
\text { Sample }\end{array}$} & \multirow{2}{*}{$\begin{array}{l}\text { Age at } \\
\text { Test } \\
\text { (Days) }\end{array}$} & \multicolumn{2}{|c|}{$\begin{array}{c}\text { Cross Section } \\
\text { Dimensions }\end{array}$} & \multirow{2}{*}{$\begin{array}{l}\text { Avg. } \\
\text { Height } \\
\text { (in.) }\end{array}$} & \multirow{2}{*}{$\begin{array}{l}\text { Net } \\
\text { Area } \\
\text { (in. }{ }^{2} \text { ) }\end{array}$} & \multirow{2}{*}{$\begin{array}{c}\text { Max } \\
\text { Load } \\
\text { (lb.) }\end{array}$} & \multirow{2}{*}{$\begin{array}{c}\text { Net } \\
\text { Comp. } \\
\text { Strength } \\
\text { (psi) }\end{array}$} & \multirow[b]{2}{*}{$\begin{array}{c}\mathrm{h} / \mathrm{t} \\
\text { Ratio }\end{array}$} & \multirow[b]{2}{*}{$\begin{array}{l}\mathrm{h} / \mathrm{t} \\
\mathrm{CF}\end{array}$} & \multirow{2}{*}{$\begin{array}{c}\text { Corrected } \\
\text { Net } \\
\text { Strength, } \\
f_{g}(\mathrm{psi})\end{array}$} \\
\hline & & $\begin{array}{l}\text { Avg. } \\
\text { Width } \\
\text { (in.) }\end{array}$ & $\begin{array}{l}\text { Avg. } \\
\text { Length } \\
\text { (in.) }\end{array}$ & & & & & & & \\
\hline $2-3-1-1$ & 130 & $33 / 4$ & 3 3/4 & 7 13/16 & 14.06 & 22000 & 1564 & 2.08 & 1.01 & 1575 \\
\hline $2-3-1-2$ & 130 & $33 / 4$ & $313 / 16$ & $73 / 4$ & 14.30 & 25000 & 1749 & 2.07 & 1.01 & 1758 \\
\hline $2-3-1-3$ & 130 & $33 / 4$ & $33 / 4$ & $73 / 4$ & 14.06 & 24000 & 1707 & 2.07 & 1.01 & 1716 \\
\hline $2-3-1-4$ & 130 & $33 / 4$ & $313 / 16$ & $711 / 16$ & 14.30 & 24000 & 1679 & 2.05 & 1.00 & 1685 \\
\hline $2-3-1-5$ & 130 & $33 / 4$ & $313 / 16$ & $75 / 8$ & 14.30 & 26000 & 1819 & 2.03 & 1.00 & 1823 \\
\hline $2-3-1-6$ & 130 & $33 / 4$ & $37 / 8$ & $711 / 16$ & 14.53 & 27000 & 1858 & 2.05 & 1.00 & 1865 \\
\hline $2-3-2-1$ & 130 & $33 / 4$ & $33 / 4$ & $711 / 16$ & 14.06 & 22000 & 1564 & 2.05 & 1.00 & 1571 \\
\hline $2-3-2-2$ & 130 & $313 / 16$ & $313 / 16$ & $713 / 16$ & 14.54 & 24000 & 1651 & 2.05 & 1.00 & 1658 \\
\hline $2-3-2-3$ & 130 & $311 / 16$ & $33 / 4$ & $711 / 16$ & 13.83 & 24000 & 1736 & 2.08 & 1.01 & 1747 \\
\hline $2-3-2-4$ & 130 & $33 / 4$ & $3 \quad 3 / 4$ & $73 / 4$ & 14.06 & 27000 & 1920 & 2.07 & 1.01 & 1930 \\
\hline $2-3-2-5$ & 130 & $33 / 4$ & $33 / 4$ & $73 / 4$ & 14.06 & 21000 & 1493 & 2.07 & 1.01 & 1501 \\
\hline $2-3-2-6$ & 130 & $311 / 16$ & $3 \quad 3 / 4$ & $75 / 8$ & 13.83 & 22000 & 1591 & 2.07 & 1.01 & 1600 \\
\hline & & & & & & & & $\mathrm{Av}$ & ge: & 1702 \\
\hline
\end{tabular}

* Height to thickness correction factor from Table 1 of ASTM C 1314. Values have been linearly interpolated as necessary

Performance of No Vibration/No Admixture Masonry Grout Containing High Replacement of Portland Cement with Fly Ash and Ground Granulated Blast Furnace Slag 


\section{C.3 Wall Compression Test Specimens: Wall 3}

ASTM C 1019 Test Report:

Standard Test Method for Sampling and Testing Grout

Testing Lab: $\quad$ CAED Concrete Lab

Project Identification: Wall Experiment, Grout Compression Tests

Grout Information:

Grout Columns ID:

Grout Type:

Date Grouted:

Date Tested:

Grout Slumps:

Method of Consolidation:

\begin{tabular}{c}
$\frac{(3-1-2) \&(3-1-3)}{100 \mathrm{C}-\mathrm{C}}$ \\
\hline $7 / 28 / 2012$ \\
\hline $12 / 5 / 2012$ \\
\hline See Appendix A.5 \\
\hline Mechanical Vibrator
\end{tabular}

Curing Time: 130 Days

Tested Grout Properties:

\begin{tabular}{|c|c|c|c|c|c|c|c|c|c|c|}
\hline \multirow{2}{*}{$\begin{array}{l}\text { Grout } \\
\text { Sample }\end{array}$} & \multirow{2}{*}{$\begin{array}{l}\text { Age at } \\
\text { Test } \\
\text { (Days) }\end{array}$} & \multicolumn{2}{|c|}{$\begin{array}{c}\text { Cross Section } \\
\text { Dimensions } \\
\end{array}$} & \multirow{2}{*}{$\begin{array}{l}\text { Avg. } \\
\text { Height } \\
\text { (in.) }\end{array}$} & \multirow{2}{*}{$\begin{array}{l}\text { Net } \\
\text { Area } \\
\text { (in. }{ }^{2} \text { ) }\end{array}$} & \multirow{2}{*}{$\begin{array}{l}\text { Max } \\
\text { Load } \\
\text { (lb.) }\end{array}$} & \multirow{2}{*}{$\begin{array}{c}\text { Net } \\
\text { Comp. } \\
\text { Strength } \\
\text { (psi) }\end{array}$} & \multirow{2}{*}{$\begin{array}{c}\mathrm{h} / \mathrm{t} \\
\text { Ratio }\end{array}$} & \multirow[b]{2}{*}{$\begin{array}{c}\mathrm{h} / \mathrm{t} \\
\mathrm{CF} *\end{array}$} & \multirow{2}{*}{$\begin{array}{l}\text { Corrected } \\
\text { Net } \\
\text { Strength, } \\
f_{g}(\mathrm{psi})\end{array}$} \\
\hline & & $\begin{array}{l}\text { Avg. } \\
\text { Width } \\
\text { (in.) }\end{array}$ & $\begin{array}{l}\text { Avg. } \\
\text { Length } \\
\text { (in.) }\end{array}$ & & & & & & & \\
\hline $3-1-2-1$ & 130 & $313 / 16$ & $37 / 8$ & $73 / 4$ & 14.77 & 49000 & 3317 & 2.03 & 1.00 & 3325 \\
\hline $3-1-2-2$ & 130 & $311 / 16$ & $3 \quad 3 / 4$ & 7 13/16 & 13.83 & 35000 & 2531 & 2.12 & 1.01 & 2555 \\
\hline $3-1-2-3$ & 130 & $33 / 4$ & $33 / 4$ & 75 5/8 & 14.06 & 41000 & 2916 & 2.03 & 1.00 & 2923 \\
\hline $3-1-2-4$ & 130 & $33 / 4$ & $313 / 16$ & $711 / 16$ & 14.30 & 41000 & 2868 & 2.05 & 1.00 & 2879 \\
\hline $3-1-2-5$ & 130 & $33 / 4$ & $33 / 4$ & $75 / 8$ & 14.06 & 37000 & 2631 & 2.03 & 1.00 & 2638 \\
\hline $3-1-2-6$ & 130 & $33 / 4$ & $33 / 4$ & $711 / 16$ & 14.06 & 43000 & 3058 & 2.05 & 1.00 & 3070 \\
\hline $3-1-3-1$ & 130 & $33 / 4$ & $33 / 4$ & $73 / 4$ & 14.06 & 44000 & 3129 & 2.07 & 1.01 & 3146 \\
\hline $3-1-3-2$ & 130 & $313 / 16$ & $37 / 8$ & $75 / 8$ & 14.77 & 41000 & 2775 & 2.00 & 1.00 & 2775 \\
\hline $3-1-3-3$ & 130 & $33 / 4$ & $313 / 16$ & $711 / 16$ & 14.30 & 44000 & 3078 & 2.05 & 1.00 & 3090 \\
\hline $3-1-3-4$ & 130 & $33 / 4$ & $33 / 4$ & $711 / 16$ & 14.06 & 39000 & 2773 & 2.05 & 1.00 & 2784 \\
\hline $3-1-3-5$ & 130 & $311 / 16$ & $311 / 16$ & $713 / 16$ & 13.60 & 39000 & 2868 & 2.12 & 1.01 & 2895 \\
\hline $3-1-3-6$ & 130 & $33 / 4$ & $313 / 16$ & $711 / 16$ & 14.30 & 43000 & 3008 & 2.05 & 1.00 & 3020 \\
\hline & & & & & & & & $\mathrm{Av}$ & & 2925 \\
\hline
\end{tabular}

* Height to thickness correction factor from Table 1 of ASTM C 1314. Values have been linearly interpolated as necessary

Performance of No Vibration/No Admixture Masonry Grout Containing High Replacement of Portland Cement with Fly Ash and Ground Granulated Blast Furnace Slag 


\section{C.3 Wall Compression Test Specimens: Wall 3}

ASTM C 1019 Test Report:

Standard Test Method for Sampling and Testing Grout

Testing Lab: $\quad$ CAED Concrete Lab

Project Identification: Wall Experiment, Grout Compression Tests

Grout Information:

Grout Columns ID:

Grout Type:

Date Grouted:

Date Tested:

Grout Slumps:

Method of Consolidation:

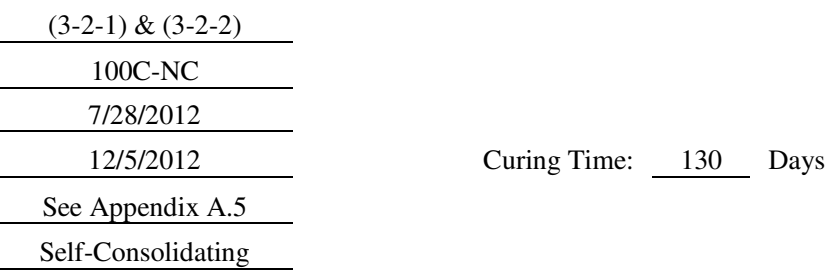

Tested Grout Properties:

\begin{tabular}{|c|c|c|c|c|c|c|c|c|c|c|}
\hline \multirow[b]{2}{*}{$\begin{array}{l}\text { Grout } \\
\text { Sample }\end{array}$} & \multirow{2}{*}{$\begin{array}{c}\text { Age at } \\
\text { Test } \\
\text { (Days) }\end{array}$} & \multicolumn{2}{|c|}{$\begin{array}{c}\text { Cross Section } \\
\text { Dimensions }\end{array}$} & \multirow{2}{*}{$\begin{array}{l}\text { Avg. } \\
\text { Height } \\
\text { (in.) }\end{array}$} & \multirow{2}{*}{$\begin{array}{l}\text { Net } \\
\text { Area } \\
\left(\text { in. } .^{2}\right)\end{array}$} & \multirow{2}{*}{$\begin{array}{l}\text { Max } \\
\text { Load } \\
\text { (lb.) }\end{array}$} & \multirow{2}{*}{$\begin{array}{c}\text { Net } \\
\text { Comp. } \\
\text { Strength } \\
\text { (psi) }\end{array}$} & \multirow{2}{*}{$\begin{array}{c}\mathrm{h} / \mathrm{t} \\
\text { Ratio }\end{array}$} & \multirow[b]{2}{*}{$\begin{array}{c}\mathrm{h} / \mathrm{t} \\
\mathrm{CF}\end{array}$} & \multirow{2}{*}{$\begin{array}{c}\text { Corrected } \\
\text { Net } \\
\text { Strength, } \\
f_{g} \text { (psi) }\end{array}$} \\
\hline & & $\begin{array}{l}\text { Avg. } \\
\text { Width } \\
\text { (in.) }\end{array}$ & $\begin{array}{l}\text { Avg. } \\
\text { Length } \\
\text { (in.) }\end{array}$ & & & & & & & \\
\hline $3-2-1-1$ & 130 & $33 / 4$ & $313 / 16$ & $75 / 8$ & 14.30 & 31000 & 2168 & 2.03 & 1.00 & 2174 \\
\hline $3-2-1-2$ & 130 & $35 / 8$ & $311 / 16$ & $75 / 8$ & 13.37 & 31000 & 2319 & 2.10 & 1.01 & 2338 \\
\hline $3-2-1-3$ & 130 & $313 / 16$ & $313 / 16$ & $7 \quad 3 / 4$ & 14.54 & 43000 & 2958 & 2.03 & 1.00 & 2966 \\
\hline $3-2-1-4$ & 130 & $3 \quad 3 / 4$ & $33 / 4$ & $711 / 16$ & 14.06 & 38000 & 2702 & 2.05 & 1.00 & 2713 \\
\hline $3-2-1-5$ & 130 & $311 / 16$ & $33 / 4$ & 7 13/16 & 13.83 & 41000 & 2965 & 2.12 & 1.01 & 2993 \\
\hline $3-2-1-6$ & 130 & $33 / 4$ & $313 / 16$ & $711 / 16$ & 14.30 & 40000 & 2798 & 2.05 & 1.00 & 2809 \\
\hline $3-2-2-1$ & 130 & $3 \quad 3 / 4$ & $313 / 16$ & $75 / 8$ & 14.30 & 38000 & 2658 & 2.03 & 1.00 & 2665 \\
\hline $3-2-2-2$ & 130 & $33 / 4$ & $313 / 16$ & $711 / 16$ & 14.30 & 38000 & 2658 & 2.05 & 1.00 & 2669 \\
\hline $3-2-2-3$ & 130 & $311 / 16$ & $33 / 4$ & $711 / 16$ & 13.83 & 37000 & 2676 & 2.08 & 1.01 & 2694 \\
\hline $3-2-2-4$ & 130 & $3 \quad 3 / 4$ & $313 / 16$ & $7 \quad 3 / 4$ & 14.30 & 41000 & 2868 & 2.07 & 1.01 & 2883 \\
\hline $3-2-2-5$ & 130 & $3 \quad 3 / 4$ & $33 / 4$ & $7 \quad 3 / 4$ & 14.06 & 41000 & 2916 & 2.07 & 1.01 & 2931 \\
\hline $3-2-2-6$ & 130 & $33 / 4$ & $313 / 16$ & $711 / 16$ & 14.30 & 44000 & 3078 & 2.05 & 1.00 & 3090 \\
\hline & & & & & & & & Av & & 2744 \\
\hline
\end{tabular}

* Height to thickness correction factor from Table 1 of ASTM C 1314. Values have been linearly interpolated as necessary

Performance of No Vibration/No Admixture Masonry Grout Containing High Replacement of Portland Cement with Fly Ash and Ground Granulated Blast Furnace Slag 


\section{Appendix D - Normalized and Averaged Compression Data from the Wall Experiment}

\section{D.1 Wall 1}

\section{D.1.1 Wall 1 Normalized Data}

Wall Compression Test Specimens Normalized to Average Corrected Net Strengths from

Compression Experiment at Curing Time 130 Days: Appendix B.6

\begin{tabular}{|c|c|c|c|c|c|c|}
\hline \multirow{2}{*}{$\begin{array}{c}\text { Height } \\
\text { from base, } \\
\text { in. }\end{array}$} & \multicolumn{7}{|c|}{ Normalized Values } \\
\cline { 2 - 7 } & $50 \mathrm{~F}$ & $50 \mathrm{~F}$ & $60 \mathrm{~F}$ & $60 \mathrm{~F}$ & $70 \mathrm{~F}$ & $70 \mathrm{~F}$ \\
\cline { 2 - 7 } & $(1-1-1)$ & $(1-1-2)$ & $(1-2-1)$ & $(1-2-2)$ & $(1-3-1)$ & $(1-3-2)$ \\
\hline & $\mathrm{NC}$ & $\mathrm{NC}$ & $\mathrm{NC}$ & $\mathrm{NC}$ & $\mathrm{NC}$ & $\mathrm{NC}$ \\
\hline 132 & 0.99 & 0.71 & 1.05 & 1.03 & 1.54 & 1.58 \\
\hline 108 & 0.91 & 0.87 & 1.10 & 1.16 & 1.38 & 1.41 \\
\hline 84 & 0.88 & 0.84 & 1.14 & 0.96 & 1.33 & 1.39 \\
\hline 60 & 0.94 & 0.92 & 1.17 & 1.24 & 1.26 & 1.63 \\
\hline 36 & 1.00 & 0.92 & 1.17 & 1.05 & 1.51 & 1.67 \\
\hline 12 & 1.02 & 0.61 & 1.09 & 0.93 & 1.39 & 1.19 \\
\hline
\end{tabular}

\section{D.1.2 Wall Compression Test Specimens: Identical Data Sets Combined and Nominalized}

Identical Data Sets Combined: Averaged compressive strength of specimens with the same grout type and at the same height along the wall.

Identical Data Sets Combined from Appendix C.1

Identical Data Sets Combined

Normalized to Average Corrected Net

Strengths from Compression

Experiment at Curing Time 130 Days:

Appendix B.6

\begin{tabular}{|c|c|c|c|}
\hline \multicolumn{4}{|c|}{ Identical Data Sets Combined } \\
\hline \multirow{2}{*}{$\begin{array}{c}\text { Height } \\
\text { from base, } \\
\text { in. }\end{array}$} & \multicolumn{3}{|c|}{$\begin{array}{c}\text { Avg. Corrected Net Strength, } \\
f_{g} \text { (psi) }\end{array}$} \\
\cline { 2 - 4 } & $50 \mathrm{~F}$ & $60 \mathrm{~F}$ & $70 \mathrm{~F}$ \\
\cline { 2 - 4 } & $\mathrm{NC}$ & $\mathrm{NC}$ & $\mathrm{NC}$ \\
\hline 132 & 1457 & 1084 & 904 \\
\hline 108 & 1523 & 1176 & 807 \\
\hline 84 & 1469 & 1094 & 786 \\
\hline 60 & 1592 & 1249 & 837 \\
\hline 36 & 1644 & 1153 & 920 \\
\hline 12 & 1391 & 1052 & 747 \\
\hline Average & 1513 & 1135 & 833 \\
\hline
\end{tabular}

\begin{tabular}{|c|c|c|c|}
\hline \multirow{2}{*}{$\begin{array}{c}\text { Height } \\
\text { from } \\
\text { base, in. }\end{array}$} & \multicolumn{3}{|c|}{ Normalized Averages } \\
\cline { 2 - 4 } & $50 \mathrm{~F}$ & $60 \mathrm{~F}$ & $70 \mathrm{~F}$ \\
\cline { 2 - 4 } & $\mathrm{NC}$ & $\mathrm{NC}$ & $\mathrm{NC}$ \\
\hline 132 & 0.85 & 1.04 & 1.56 \\
\hline 108 & 0.89 & 1.13 & 1.39 \\
\hline 84 & 0.86 & 1.05 & 1.36 \\
\hline 60 & 0.93 & 1.20 & 1.45 \\
\hline 36 & 0.96 & 1.11 & 1.59 \\
\hline 12 & 0.81 & 1.01 & 1.29 \\
\hline Average & 0.88 & 1.09 & 1.44 \\
\hline
\end{tabular}

Performance of No Vibration/No Admixture Masonry Grout Containing High Replacement of Portland Cement with Fly Ash and Ground Granulated Blast Furnace Slag 


\section{D.2 Wall 2}

\section{D.2.1 Wall 2 Normalized Data}

Wall Compression Test Specimens Normalized to Average Corrected Net Strengths from Compression Experiment at Curing Time 130 Days: Appendix B.6

\begin{tabular}{|c|c|c|c|c|c|c|}
\hline \multirow{2}{*}{$\begin{array}{c}\text { Height } \\
\text { from base, } \\
\text { in. }\end{array}$} & \multicolumn{7}{|c|}{ Normalized Values } \\
\cline { 2 - 7 } & $60 \mathrm{SF}$ & $60 \mathrm{SF}$ & $70 \mathrm{SF}$ & $70 \mathrm{SF}$ & $80 \mathrm{SF}$ & $80 \mathrm{SF}$ \\
\cline { 2 - 7 } & $(2-1-1)$ & $(2-1-2)$ & $(2-2-1)$ & $(2-2-2)$ & $(2-3-1)$ & $(2-3-2)$ \\
\hline 132 & $\mathrm{NC}$ & $\mathrm{NC}$ & $\mathrm{NC}$ & $\mathrm{NC}$ & $\mathrm{NC}$ & $\mathrm{NC}$ \\
\hline 108 & 0.80 & 1.23 & 0.77 & 0.86 & 0.89 & 0.76 \\
\hline 84 & 0.81 & 1.13 & 0.83 & 0.79 & 0.87 & 0.72 \\
\hline 60 & 1.02 & 1.16 & 0.90 & 0.81 & 0.81 & 0.92 \\
\hline 36 & 1.06 & 1.16 & 0.84 & 0.83 & 0.82 & 0.83 \\
\hline 12 & 0.75 & 0.90 & 0.77 & 0.79 & 0.84 & 0.79 \\
\hline
\end{tabular}

\section{D.2.2 Wall Compression Test Specimens: Identical Data Sets Combined and Nominalized}

Identical Data Sets Combined: Averaged compressive strength of specimens with the same grout type and at the same height along the wall.

Identical Data Sets Combined from Appendix C.2

\begin{tabular}{|c|c|c|c|}
\hline \multicolumn{4}{|c|}{ Identical Data Sets Combined } \\
\hline \multirow{2}{*}{$\begin{array}{c}\text { Height } \\
\text { from base, } \\
\text { in. }\end{array}$} & \multicolumn{3}{|c|}{$\begin{array}{c}\text { Avg. Corrected Net Strength, } \\
f_{g} \text { (psi) }\end{array}$} \\
\cline { 2 - 4 } & $60 \mathrm{SF}$ & $70 \mathrm{SF}$ & $80 \mathrm{SF}$ \\
\cline { 2 - 4 } & $\mathrm{NC}$ & $\mathrm{NC}$ & $\mathrm{NC}$ \\
\hline 132 & 2261 & 1939 & 1733 \\
\hline 108 & 2161 & 1927 & 1662 \\
\hline 84 & 2393 & 2040 & 1808 \\
\hline 60 & 2370 & 1985 & 1732 \\
\hline 36 & 2474 & 1970 & 1708 \\
\hline 12 & 1839 & 1914 & 1573 \\
\hline Average & 2250 & 1963 & 1702 \\
\hline
\end{tabular}

Identical Data Sets Combined Normalized to Average Corrected Net Strengths from Compression Experiment at Curing Time 130 Days: Appendix B.6

\begin{tabular}{|c|c|c|c|}
\hline \multirow{2}{*}{$\begin{array}{c}\text { Height } \\
\text { from } \\
\text { base, in. }\end{array}$} & \multicolumn{3}{|c|}{ Normalized Averages } \\
\cline { 2 - 4 } & $60 \mathrm{SF}$ & $70 \mathrm{SF}$ & $80 \mathrm{SF}$ \\
\cline { 2 - 4 } & $\mathrm{NC}$ & $\mathrm{NC}$ & $\mathrm{NC}$ \\
\hline 132 & 1.01 & 0.81 & 0.83 \\
\hline 108 & 0.97 & 0.81 & 0.79 \\
\hline 84 & 1.07 & 0.86 & 0.86 \\
\hline 60 & 1.06 & 0.83 & 0.83 \\
\hline 36 & 1.11 & 0.83 & 0.82 \\
\hline 12 & 0.83 & 0.80 & 0.75 \\
\hline Average & 1.01 & 0.82 & 0.81 \\
\hline
\end{tabular}

Performance of No Vibration/No Admixture Masonry Grout Containing High Replacement of Portland Cement with Fly Ash and Ground Granulated Blast Furnace Slag 


\section{D.3 Wall 3}

\section{D.3.1 Wall 3 Normalized Data}

Wall Compression Test Specimens Normalized to Average Corrected Net Strengths from Compression Experiment at Curing Time 130 Days: Appendix B.6

\begin{tabular}{|c|c|c|c|c|}
\hline \multirow{2}{*}{$\begin{array}{c}\text { Height } \\
\text { from } \\
\text { base, in. }\end{array}$} & \multicolumn{4}{|c|}{ Normalized Values } \\
\cline { 2 - 5 } & $100 \mathrm{C}-\mathrm{C}$ & $100 \mathrm{C}-\mathrm{C}$ & $\begin{array}{c}100 \mathrm{C}- \\
\text { NC }\end{array}$ & $\begin{array}{c}100 \mathrm{C}- \\
\text { NC }\end{array}$ \\
\cline { 2 - 5 } & $(3-1-2)$ & $(3-1-3)$ & $(3-2-1)$ & $(3-2-2)$ \\
\hline 132 & $\mathrm{C}$ & $\mathrm{C}$ & $\mathrm{NC}$ & $\mathrm{NC}$ \\
\hline 108 & 0.91 & 0.90 & 0.83 & 0.92 \\
\hline 84 & 0.85 & 0.86 & 0.89 & 0.87 \\
\hline 60 & 0.87 & 0.93 & 0.80 & 0.85 \\
\hline 36 & 0.76 & 0.82 & 0.88 & 0.80 \\
\hline 12 & 0.99 & 0.93 & 0.64 & 0.79 \\
\hline
\end{tabular}

\section{D.3.2 Wall Compression Test Specimens: Identical Data Sets Combined and Nominalized}

Identical Data Sets Combined: Averaged compressive strength of specimens with the same grout type and at the same height along the wall.

Identical Data Sets Combined from Appendix C.3

\begin{tabular}{|c|c|c|}
\hline \multicolumn{2}{|c|}{ Identical Data Sets Combined } \\
\hline \multirow{2}{*}{$\begin{array}{c}\text { Height } \\
\text { from } \\
\text { base, in. }\end{array}$} & \multicolumn{2}{|c|}{$\begin{array}{c}\text { Avg. Corrected Net } \\
\text { Strength, } f_{g}(\mathrm{psi})\end{array}$} \\
\cline { 2 - 3 } & $100 \mathrm{C}-\mathrm{C}$ & $\begin{array}{c}100 \mathrm{C}- \\
\text { NC }\end{array}$ \\
\cline { 2 - 3 } & $\mathrm{C}$ & NC \\
\hline 132 & 3045 & 2949 \\
\hline 108 & 2767 & 2962 \\
\hline 84 & 2832 & 2798 \\
\hline 60 & 3007 & 2830 \\
\hline 36 & 2665 & 2503 \\
\hline 12 & 3236 & 2420 \\
\hline Average & 2925 & 2744 \\
\hline
\end{tabular}

Identical Data Sets Combined Normalized to Average Corrected Net Strengths from Compression Experiment at Curing Time 130 Days: $\quad$ Appendix B.6

\begin{tabular}{|c|c|c|}
\hline \multirow{2}{*}{$\begin{array}{c}\text { Height } \\
\text { from } \\
\text { base, in. }\end{array}$} & \multicolumn{2}{|c|}{ Normalized Averages } \\
\cline { 2 - 3 } & $100 \mathrm{C}-\mathrm{C}$ & $100 \mathrm{C}-\mathrm{NC}$ \\
\cline { 2 - 3 } & $\mathrm{C}$ & $\mathrm{NC}$ \\
\hline 132 & 0.90 & 0.87 \\
\hline 108 & 0.82 & 0.88 \\
\hline 84 & 0.84 & 0.83 \\
\hline 60 & 0.89 & 0.84 \\
\hline 36 & 0.79 & 0.74 \\
\hline 12 & 0.96 & 0.72 \\
\hline Average & 0.87 & 0.81 \\
\hline
\end{tabular}

Performance of No Vibration/No Admixture Masonry Grout Containing High Replacement of Portland Cement with Fly Ash and Ground Granulated Blast Furnace Slag 


\section{Appendix E - Consolidation Characteristics of Wall Compression Test Specimens}

\section{E.1 Top View of Wall Compression Specimens}

Below are pictures of the top view sections of wall compression test specimens before final cutting of 4" $\mathrm{x} 4$ " $\mathrm{x} 8$ " (nominal)

Descriptions next to pictures show how the specimens were visually classified in Appendix E.3

All specimens showed no evidence of segregation of aggregates

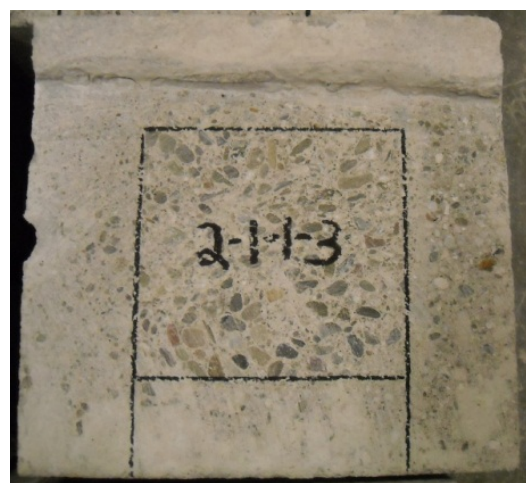

Top View of 2-1-1-3

No evidence of air voids

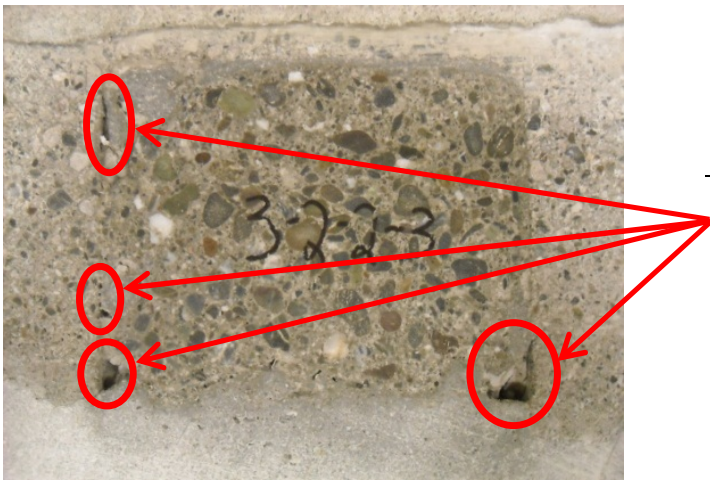

Top View of 3-2-2-3

$1 / 16 "$ to $1 / 2 "$ mortar*

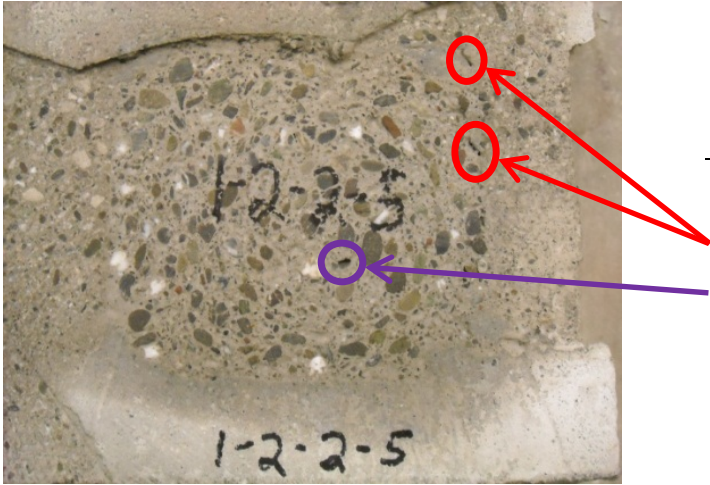

Top View of 1-2-2-5

$1 / 16^{\prime \prime}$ mortar*

$1 / 16 "$ air void

Chipped**

*Air Voids located near the mortar fins

**Some aggregate chipped off during cutting due to its low strength

Performance of No Vibration/No Admixture Masonry Grout Containing High Replacement of Portland Cement with Fly Ash and Ground Granulated Blast Furnace Slag 


\section{E.2 Side View of Wall Compression Specimens}

Below are pictures of the side view sections of wall compression test specimens after final cutting of $4 " \mathrm{x} 4$ " $\mathrm{x} 8$ " (nominal)

Descriptions next to pictures show how the specimens were visually classified in Appendix E.3

All specimens showed no evidence of segregation of aggregates

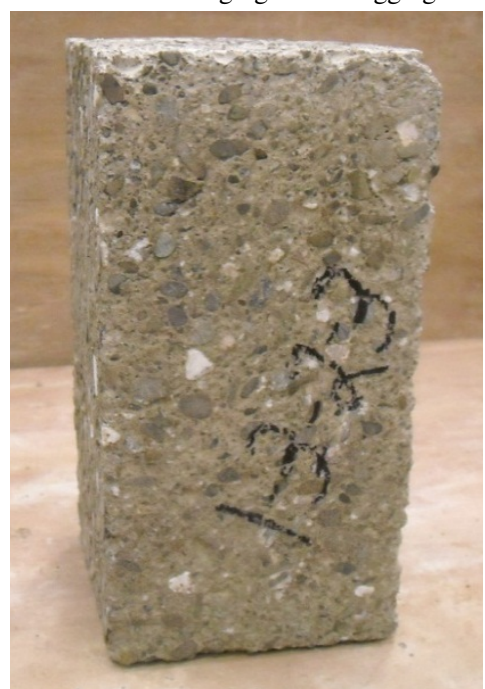

Side View of 1-3-2-3

No evidence of air voids

Chipped**

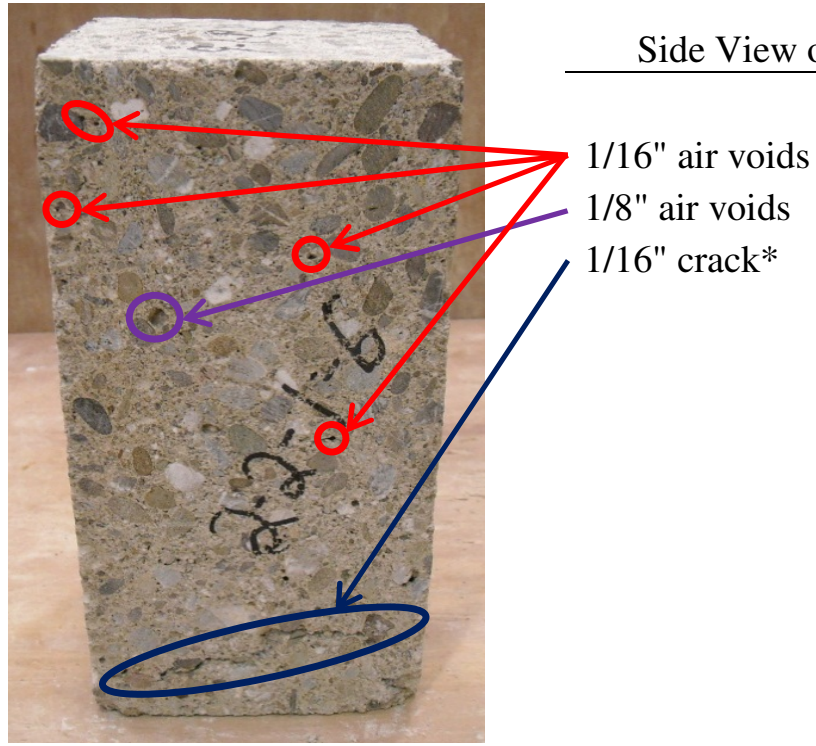

*1/16" thick crack (void)

**Some aggregate chipped off during cutting due to its low strength

Performance of No Vibration/No Admixture Masonry Grout Containing High Replacement of Portland Cement with Fly Ash and Ground Granulated Blast Furnace Slag 


\section{E.3 Recorded Visual Consolidation Characteristics of Wall Compression Specimens}

\section{E.3.1 Wall 1}

\begin{tabular}{|c|c|c|c|}
\hline$\stackrel{\text { on }}{\text { Specimen }}$ & $1-1-1-6$ & $1-1-2-6$ & $1-2-1-6$ \\
\hline Top: & $1 / 16^{\prime \prime}$ mortar & $1 / 16^{\prime \prime}$ mortar & Chipped, No evidence of air voids \\
\hline \multirow[t]{2}{*}{ Side: } & No evidence of air voids & No evidence of air voids & Chipped, 1/4" air voids \\
\hline & $1-1-1-5$ & $1-1-2-5$ & $1-2-1-5$ \\
\hline Top: & No evidence of air voids & $1 / 16^{\prime \prime}$ mortar & Chipped, 1/16" mortar \\
\hline \multirow[t]{2}{*}{ Side: } & 1/16" crack, $1 / 16^{\prime \prime}$ air voids & $1 / 16^{\prime \prime}-1 / 8 "$ air voids & Chipped, 1/8" air voids \\
\hline & $1-1-1-4$ & $1-1-2-4$ & $1-2-1-4$ \\
\hline Top: & No evidence of air voids & 1/16" mortar & Chipped, No evidence of air voids \\
\hline \multirow[t]{2}{*}{ Side: } & 1/16" crack, $1 / 16 "$ air voids & 1/16" - 1/8" air voids & Chipped, 1/16" air voids \\
\hline & $1-1-1-3$ & $1-1-2-3$ & $1-2-1-3$ \\
\hline Top: & 1/16" mortar & No evidence of air voids & Chipped, No evidence of air voids \\
\hline \multirow[t]{2}{*}{ Side: } & 1/8" crack, $1 / 16 "$ air voids & 1/16" air voids & Chipped \\
\hline & $1-1-1-2$ & $1-1-2-2$ & $1-2-1-2$ \\
\hline \multirow{3}{*}{$\begin{array}{l}\text { Top: } \\
\text { Side: }\end{array}$} & No evidence of air voids & No evidence of air voids & Chipped, No evidence of air voids \\
\hline & 1/16" air voids & 1/16" - 1/8" air voids & Chipped, 1/16" air voids \\
\hline & $1-1-1-1$ & $1-1-2-1$ & $1-2-1-1$ \\
\hline \multirow{2}{*}{$\begin{array}{l}\text { Top: } \\
\text { Side: }\end{array}$} & 1/16" mortar & No evidence of air voids & Chipped, 1/16" mortar \\
\hline & 1/16" air voids & $1 / 16^{\prime \prime}-1 / 4 "$ air voids & Chipped, 1/16" - 1/8" air voids \\
\hline
\end{tabular}

\section{F, 1-1-1, NC}

50F, 1-1-2, NC

60F, 1-2-1, NC

\begin{tabular}{|c|c|c|c|}
\hline \multicolumn{4}{|l|}{$\underline{\text { Location }}$} \\
\hline$\underset{\text { Specimen }}{\stackrel{\text { on }}{\text { Sim }}}$ & $1-2-2-6$ & $1-3-1-6$ & $1-3-2-6$ \\
\hline Top: & Chipped, No evidence of air voids & Chipped, No evidence of air voids & Chipped, 1/16" mortar \\
\hline \multirow[t]{2}{*}{ Side: } & Chipped, 1/16" air voids & Chipped, 1/16" air voids & Chipped, 1/16" air voids \\
\hline & $1-2-2-5$ & $1-3-1-5$ & $1-3-2-5$ \\
\hline \multirow{3}{*}{$\begin{array}{l}\text { Top: } \\
\text { Side: }\end{array}$} & Chipped, 1/16" mortar, 1/16" air void & Chipped, No evidence of air voids & Chipped, No evidence of air voids \\
\hline & Chipped & Chipped, 1/16" - 1/8" air voids & Chipped, 1/16" air voids \\
\hline & $1-2-2-4$ & $1-3-1-4$ & $1-3-2-4$ \\
\hline \multirow{3}{*}{$\begin{array}{l}\text { Top: } \\
\text { Side: }\end{array}$} & Chipped, No evidence of air voids & Chipped, No evidence of air voids & Chipped, 1/8" air void \\
\hline & Chipped, 1/16" - 1/8" air voids & Chipped, 1/16" air voids & Chipped, 1/16" air voids \\
\hline & $1-2-2-3$ & $1-3-1-3$ & $1-3-2-3$ \\
\hline \multirow{3}{*}{$\begin{array}{l}\text { Top: } \\
\text { Side: }\end{array}$} & Chipped, No evidence of air voids & Chipped, No evidence of air voids & Chipped, No evidence of air voids \\
\hline & Chipped, 1/16" air voids & Chipped, 1/16" air voids & Chipped \\
\hline & $1-2-2-2$ & $1-3-1-2$ & $1-3-2-2$ \\
\hline \multirow{3}{*}{$\begin{array}{l}\text { Top: } \\
\text { Side: }\end{array}$} & Chipped, No evidence of air voids & Chipped, No evidence of air voids & Chipped, No evidence of air voids \\
\hline & Chipped, 1/16" - 1/8" air voids & Chipped, 1/16" air voids & Chipped, 1/16" air voids \\
\hline & $1-2-2-1$ & $1-3-1-1$ & $1-3-2-1$ \\
\hline \multirow{2}{*}{$\begin{array}{l}\text { Top: } \\
\text { Side: }\end{array}$} & Chipped, 1/8" - 1/2" mortar & Chipped, 1/8" mortar & $\begin{array}{l}\text { Majorly Chipped, } 1 / 8 " \text { mortar, } \\
1 / 8 \text { " air voids }\end{array}$ \\
\hline & Chipped, 1/16" - 1/4" air voids & Chipped, 1/16" - 1/8" air voids & Chipped, 1/16" - 1/8" air voids \\
\hline
\end{tabular}

$$
\text { 60F, 1-2-2, NC 70F, 1-3-1, NC 70F, 1-3-2, NC }
$$

Performance of No Vibration/No Admixture Masonry Grout Containing High Replacement of

Portland Cement with Fly Ash and Ground Granulated Blast Furnace Slag 


\section{E.3 Recorded Visual Consolidation Characteristics of Wall Compression Specimens}

\section{E.3.2 Wall 2}

\begin{tabular}{|c|c|c|c|}
\hline \multicolumn{4}{|l|}{ Location on } \\
\hline Specimen & $2-1-1-6$ & $2-1-2-6$ & $2-2-1-6$ \\
\hline Top: & $1 "$ mortar & No evidence of air voids & No evidence of air voids \\
\hline \multirow[t]{2}{*}{ Side: } & 1/16" - 1/8" air voids & 1/16" air voids & 1/16" crack, $1 / 16 "$ - 1/8" air voids \\
\hline & $2-1-1-5$ & $2-1-2-5$ & $2-2-1-5$ \\
\hline Top: & No evidence of air voids & No evidence of air voids & No evidence of air voids \\
\hline \multirow[t]{2}{*}{ Side: } & 1/16" - 1/8" air voids & 1/16" air voids & 1/16" air voids \\
\hline & $2-1-1-4$ & $2-1-2-4$ & $2-2-1-4$ \\
\hline Top: & No evidence of air voids & $1 / 16^{\prime \prime}$ mortar & No evidence of air voids \\
\hline \multirow[t]{2}{*}{ Side: } & 1/16" - 1/8" air voids & 1/16" - 1/8" air voids & 1/16" - 1/8" air voids \\
\hline & $2-1-1-3$ & $2-1-2-3$ & $2-2-1-3$ \\
\hline Top: & No evidence of air voids & $1 / 16^{\prime \prime}$ mortar & No evidence of air voids \\
\hline \multirow[t]{2}{*}{ Side: } & 1/16" air voids & $1 / 16^{\prime \prime}-1 / 8 "$ air voids & 1/16" air voids \\
\hline & $2-1-1-2$ & $2-1-2-2$ & $2-2-1-2$ \\
\hline Top: & No evidence of air voids & No evidence of air voids & No evidence of air voids \\
\hline \multirow[t]{2}{*}{ Side: } & 1/16" - 1/8" air voids & 1/16" - 1/8" air voids & 1/16" - 1/8" air voids \\
\hline & $2-1-1-1$ & $2-1-2-1$ & $2-2-1-1$ \\
\hline Top: & 1/16" air voids & $1 / 8^{\prime \prime}-1 / 4 "$ mortar & No evidence of air voids \\
\hline \multirow[t]{2}{*}{ Side: } & 1/16" - 1/8" air voids & 1/16" - 1/4" air voids & $1 / 16 "$ - 1/8" air voids \\
\hline & 60SF, 2-1-1, NC & 60SF, 2-1-2, NC & 70SF, 2-2-1, NC \\
\hline \multicolumn{4}{|l|}{$\underline{\text { Location on }}$} \\
\hline Specimen & $2-2-2-6$ & $2-3-1-6$ & $2-3-2-6$ \\
\hline Top: & No evidence of air voids & 1/16" mortar & 1/16" mortar \\
\hline \multirow[t]{2}{*}{ Side: } & 1/16" - 1/8" air voids & $1 / 16^{\prime \prime}-1 / 8 "$ air voids & 1/16" - 1/8" air voids \\
\hline & $2-2-2-5$ & $2-3-1-5$ & $2-3-2-5$ \\
\hline Top: & No evidence of air voids & No evidence of air voids & No evidence of air voids \\
\hline \multirow[t]{2}{*}{ Side: } & 1/16" - 1/8" air voids & $1 / 16^{\prime \prime}-1 / 8 "$ air voids & $1 / 16 "$ - 1/8" air voids \\
\hline & $2-2-2-4$ & $2-3-1-4$ & $2-3-2-4$ \\
\hline Top: & 1/8" air void & No evidence of air voids & No evidence of air voids \\
\hline \multirow[t]{2}{*}{ Side: } & 1/16" air voids & 1/16" air voids & 1/16" air voids \\
\hline & $2-2-2-3$ & $2-3-1-3$ & $2-3-2-3$ \\
\hline Top: & No evidence of air voids & $1 / 16 "$ mortar & No evidence of air voids \\
\hline \multirow[t]{2}{*}{ Side: } & 1/16" air voids & 1/16" - 1/8" air voids & 1/16" air voids \\
\hline & $2-2-2-2$ & $2-3-1-2$ & $2-3-2-2$ \\
\hline Top: & No evidence of air voids & No evidence of air voids & No evidence of air voids \\
\hline \multirow[t]{2}{*}{ Side: } & 1/16" - 1/8" air voids & 1/16" - 1/8" air voids & 1/16" - 1/8" air voids \\
\hline & $2-2-2-1$ & $2-3-1-1$ & $2-3-2-1$ \\
\hline Top: & 1/16" air void & 1/16" mortar & 1/16" mortar \\
\hline Side: & 1/16" - 1/8" air voids & 1/16" - 1/8" air voids & 1/16" air voids \\
\hline
\end{tabular}

70SF, 2-2-2, NC 80SF, 2-3-1, NC $\quad$ 80SF, 2-3-2, NC

Performance of No Vibration/No Admixture Masonry Grout Containing High Replacement of Portland Cement with Fly Ash and Ground Granulated Blast Furnace Slag 
E.3 Recorded Visual Consolidation Characteristics of Wall

Compression Specimens

\section{E.3.3 Wall 3}

\begin{tabular}{|c|c|c|}
\hline \multicolumn{3}{|l|}{ Location on } \\
\hline$\underline{\text { Specimen }}$ & $3-1-2-6$ & $3-1-3-6$ \\
\hline Top: & 1/16" mortar & No evidence of air voids \\
\hline \multirow[t]{2}{*}{ Side: } & 1/16" crack, 1/16" - 1/8" air voids & 1/16" crack, 1/16" - 1/8" air voids \\
\hline & $3-1-2-5$ & $3-1-3-5$ \\
\hline Top: & 1/16" mortar & No evidence of air voids \\
\hline \multirow[t]{2}{*}{ Side: } & $1 / 8 "$ crack, $1 / 16 "$ air voids & 1/16" - 1/8" air voids \\
\hline & $3-1-2-4$ & $3-1-3-4$ \\
\hline Top: & No evidence of air voids & No evidence of air voids \\
\hline \multirow[t]{2}{*}{ Side: } & 1/16" crack, 1/16" air voids & 1/16" crack, 1/16" - 1/8" air voids \\
\hline & $3-1-2-3$ & $3-1-3-3$ \\
\hline Top: & 1/16" mortar & No evidence of air voids \\
\hline \multirow[t]{2}{*}{ Side: } & 1/16" air voids & 1/16" - 1/8" air voids \\
\hline & $3-1-2-2$ & $3-1-3-2$ \\
\hline Top: & No evidence of air voids & No evidence of air voids \\
\hline \multirow[t]{2}{*}{ Side: } & 1/16" - 1/4" air voids & $1 / 16^{\prime \prime}-1 / 8 "$ air voids \\
\hline & $3-1-2-1$ & $3-1-3-1$ \\
\hline Top: & No evidence of air voids & No evidence of air voids \\
\hline \multirow[t]{2}{*}{ Side: } & 1/8" air voids & 1/16" - 1/8" air voids \\
\hline & 100C, 3-1-2, C & 100C, 3-1-3, C \\
\hline \multicolumn{3}{|l|}{ Location on } \\
\hline Specimen & $3-2-1-6$ & $3-2-2-6$ \\
\hline Top: & 1/4"mortar & 1/16" mortar \\
\hline \multirow[t]{2}{*}{ Side: } & 1/16" - 1/4" air voids & $1 / 16^{\prime \prime}-1 / 8 "$ air voids \\
\hline & $3-2-1-5$ & $3-2-2-5$ \\
\hline Top: & No evidence of air voids & 1/16" mortar \\
\hline \multirow[t]{2}{*}{ Side: } & 1/16" - 1/8" air voids & 1/16" - 1/8" air voids \\
\hline & $3-2-1-4$ & $3-2-2-4$ \\
\hline Top: & No evidence of air voids & 1/16" - 1/4" mortar \\
\hline \multirow[t]{2}{*}{ Side: } & 1/16" - 1/8" air voids & 1/16" - 1/8" air voids \\
\hline & $3-2-1-3$ & $3-2-2-3$ \\
\hline Top: & 1/16" mortar & $1 / 16^{\prime \prime}-1 / 2^{\prime \prime}$ mortar \\
\hline \multirow[t]{2}{*}{ Side: } & 1/16" - 1/8" air voids & 1/16" - 1/8" air voids \\
\hline & $3-2-1-2$ & $3-2-2-2$ \\
\hline Top: & No evidence of air voids & $1 / 8 "$ mortar \\
\hline \multirow[t]{2}{*}{ Side: } & 1/16" - 1/8" air voids & 1/16" crack, 1/16" - 1/8" air voids \\
\hline & $3-2-1-1$ & $3-2-2-1$ \\
\hline Top: & 1/4" mortar & $1 / 8 "$ mortar \\
\hline Side: & 1/16" - 1/8" air voids & 1/16" - 1/4" air voids \\
\hline
\end{tabular}

100C, 3-2-1, NC

$100 \mathrm{C}, 3-2-2, \mathrm{NC}$

Performance of No Vibration/No Admixture Masonry Grout Containing High Replacement of Portland Cement with Fly Ash and Ground Granulated Blast Furnace Slag 


\section{Appendix F - Consolidation Characteristics of Reinforcement Sections}

\section{F.1 Pictures of Cross Sections through Reinforcement Layers}

Below are pictures of the vertical cuts across the mid-section of the grout columns at the reinforcement layers.

Descriptions next to pictures show how the specimens were visually classified in Appendix F.2

Consolidation grades are determined by diameter of air void size, following Table 5.

All specimens showed no evidence of segregation of aggregates
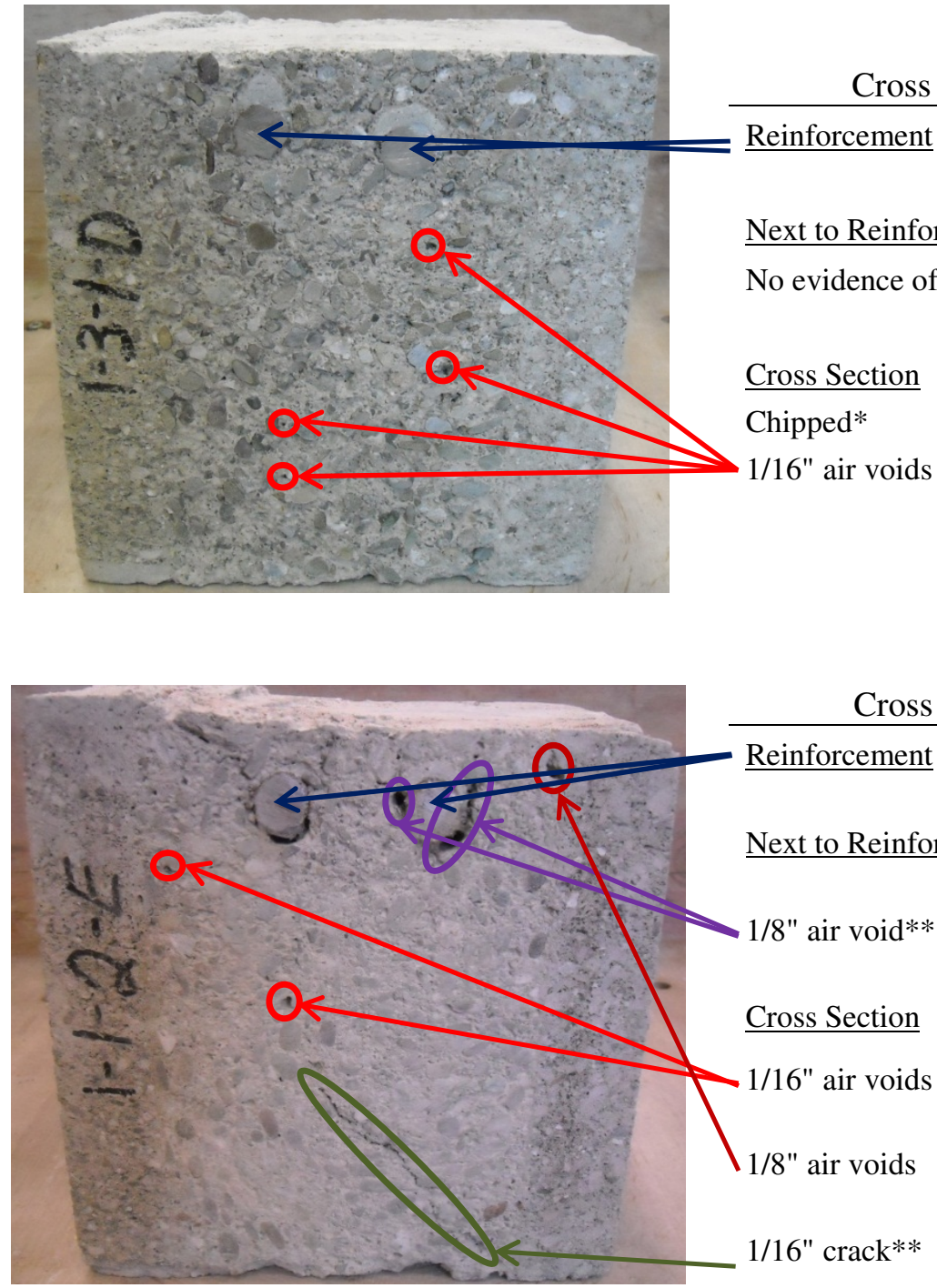

Cross Section of 1-1-2-E

$\underline{\text { Reinforcement }}$

$\underline{\text { Next to Reinforcement }}$

1/8" air void***

$\underline{\text { Cross Section }}$

1/16" air voids

$1 / 8$ " air voids

$1 / 16^{\prime \prime} \operatorname{crack}^{* *}$

*Some aggregate chipped off during cutting due to its low strength

** 1/16" thick crack (void)

***Largest air void next to reinforcement of section is $1 / 8 "$

Performance of No Vibration/No Admixture Masonry Grout Containing High Replacement of Portland Cement with Fly Ash and Ground Granulated Blast Furnace Slag 


\section{F.2 Recorded Visual Consolidation Characteristics of Cross Section through Reinforcement Layers}

\section{F.2.1 Wall 1}

\section{F.2.1.1 Mixture 50F}

Consolidation Grade:

Cross Section:

Next to Reinforcement:

Consolidation Grade:

Cross Section:

Next to Reinforcement:

Consolidation Grade:

Cross Section:

Next to Reinforcement:

Consolidation Grade:

Cross Section:

Next to Reinforcement:

Consolidation Grade:

Cross Section:

Next to Reinforcement:

Consolidation Grade:

Cross Section:

Next to Reinforcement:

\begin{tabular}{|c|c|}
\hline $1-1-1-\mathrm{F}$ & $1-1-2-F$ \\
\hline 2 & 1 \\
\hline 1/8" crack, $1 / 16 "$ - 1/8" air voids & 1/16" air voids \\
\hline 1/8" air void & No evidence of air voids \\
\hline $1-1-1-E$ & $1-1-2-E$ \\
\hline 2 & 2 \\
\hline 1/16"- $1 / 8$ " air voids & 1/16" crack, $1 / 16^{\prime \prime}$ - 1/8" air voids \\
\hline 1/16" air void & 1/8" air void \\
\hline 1-1-1-D & $1-1-2-D$ \\
\hline 2 & 2 \\
\hline 1/16" air voids & 1/16" air voids \\
\hline 1/16" air void & 1/8" air void \\
\hline $1-1-1-\mathrm{C}$ & $1-1-2-C$ \\
\hline 2 & 2 \\
\hline 1/16" crack, $1 / 16 "$ - 1/8" air voids & 1/16"- $1 / 8 "$ air voids \\
\hline 1/8" air void & 1/8" air void \\
\hline $1-1-1-B$ & $1-1-2-B$ \\
\hline 2 & 2 \\
\hline 1/16" crack, $1 / 16 "$ - 1/8" air voids & 1/16"- 1/8" air voids \\
\hline 1/8" air void & 1/8" air void \\
\hline $1-1-1-\mathrm{A}$ & $1-1-2-A$ \\
\hline 5 & 2 \\
\hline 1/16" - 3/8" air voids & 1/16"- 1/8" air voids \\
\hline 1/8" air void & 1/8" air void \\
\hline
\end{tabular}

$$
\text { 50F, 1-1-1, NC }
$$

Average Grout Consolidation Grade: $\underline{\mathbf{2 . 2}}$

Performance of No Vibration/No Admixture Masonry Grout Containing High Replacement of Portland Cement with Fly Ash and Ground Granulated Blast Furnace Slag 


\section{F.2.1.2 Mixture 60F}

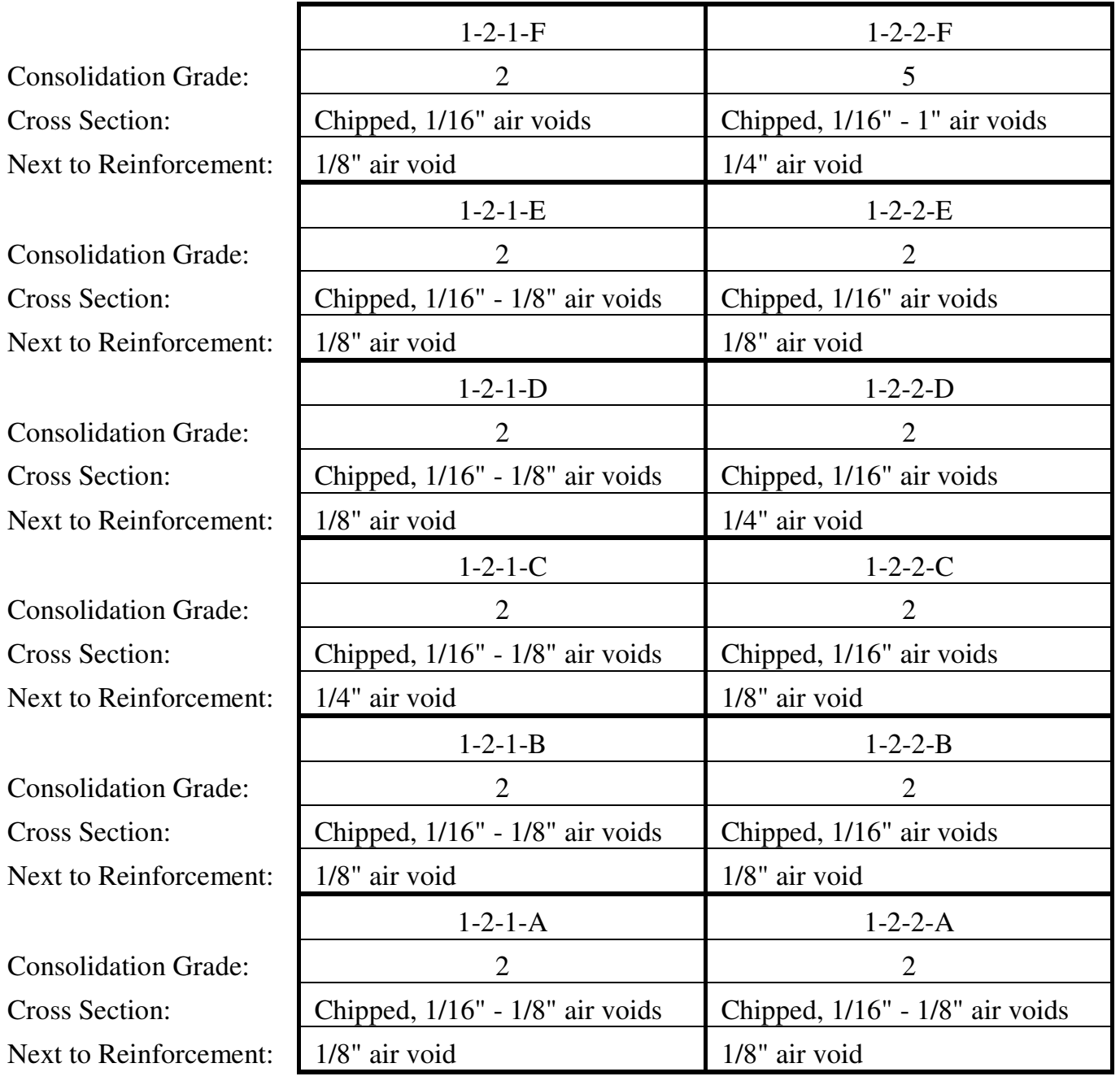

$$
60 \mathrm{~F}, 1-2-1, \mathrm{NC} \quad 60 \mathrm{~F}, 1-2-2, \mathrm{NC}
$$

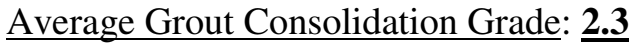




\section{F2.1.3 Mixture 70F}

Consolidation Grade:

Cross Section:

Next to Reinforcement:

Consolidation Grade:

Cross Section:

Next to Reinforcement:

Consolidation Grade:

Cross Section:

Next to Reinforcement:

Consolidation Grade:

Cross Section:

Next to Reinforcement:

Consolidation Grade:

Cross Section:

Next to Reinforcement:

Consolidation Grade:

Cross Section:

Next to Reinforcement:

\begin{tabular}{|c|c|}
\hline $1-3-1-F$ & $1-3-2-\mathrm{F}$ \\
\hline 2 & 1 \\
\hline Chipped, 1/16" - 1/8" air voids & Chipped, 1/16" air voids \\
\hline 1/8" air void & No evidence of air voids \\
\hline $1-3-1-E$ & $1-3-2-E$ \\
\hline 2 & 2 \\
\hline Chipped, 1/16" - 1/8" air voids & Chipped, 1/16" air voids \\
\hline 1/16" air void & 1/16" air void \\
\hline 1-3-1-D & 1-3-2-D \\
\hline 1 & 2 \\
\hline Chipped, 1/16" air voids & Chipped, 1/16" air voids \\
\hline No evidence of air voids & 1/16" air void \\
\hline $1-3-1-\mathrm{C}$ & $1-3-2-\mathrm{C}$ \\
\hline 2 & 2 \\
\hline Chipped, 1/16" air voids & Chipped, 1/16" - 1/8" air voids \\
\hline 1/16" air void & 1/16" air void \\
\hline $1-3-1-B$ & $1-3-2-B$ \\
\hline 2 & 2 \\
\hline Chipped, 1/16" - 1/8" air voids & Chipped, 1/16" air voids \\
\hline 1/16" air void & 1/8" air void \\
\hline $1-3-1-\mathrm{A}$ & $1-3-2-\mathrm{A}$ \\
\hline 2 & 1 \\
\hline Chipped, 1/16" - 1/8" air voids & Chipped, 1/16" air voids \\
\hline 1/4" air void & No evidence of air voids \\
\hline
\end{tabular}

70F, 1-3-1, NC

70F, 1-3-2, NC

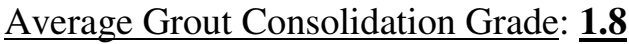

Performance of No Vibration/No Admixture Masonry Grout Containing High Replacement of Portland Cement with Fly Ash and Ground Granulated Blast Furnace Slag 


\section{F.2.2 Wall 2}

\section{F2.2.1 Mixture 60SF}

\begin{tabular}{|c|c|c|}
\hline \multirow{5}{*}{$\begin{array}{l}\text { Consolidation Grade: } \\
\text { Cross Section: } \\
\text { Next to Reinforcement: }\end{array}$} & $2-1-1-\mathrm{F}$ & $2-1-2-\mathrm{F}$ \\
\hline & 2 & 2 \\
\hline & 1/16"- 1/8" air voids & $1 / 16 "-1 / 4 "$ air voids \\
\hline & 1/16" air void & 1/4" air void \\
\hline & $2-1-1-\mathrm{E}$ & $2-1-2-E$ \\
\hline \multirow{4}{*}{$\begin{array}{l}\text { Consolidation Grade: } \\
\text { Cross Section: } \\
\text { Next to Reinforcement: }\end{array}$} & 1 & 2 \\
\hline & 1/16" air voids & 1/16"- 1/8" air voids \\
\hline & No evidence of air voids & 1/8" air void \\
\hline & 2-1-1-D & 2-1-2-D \\
\hline \multirow{4}{*}{$\begin{array}{l}\text { Consolidation Grade: } \\
\text { Cross Section: } \\
\text { Next to Reinforcement: }\end{array}$} & 2 & 2 \\
\hline & $1 / 16 "-1 / 4 "$ air voids & 1/16"- 1/8" air voids \\
\hline & 1/4" air void & 1/4" air void \\
\hline & $2-1-1-\mathrm{C}$ & $2-1-2-C$ \\
\hline \multirow{4}{*}{$\begin{array}{l}\text { Consolidation Grade: } \\
\text { Cross Section: } \\
\text { Next to Reinforcement: }\end{array}$} & 2 & 2 \\
\hline & 1/16"- 1/8" air voids & 1/16"- 1/8" air voids \\
\hline & 1/4" air void & 1/8" air void \\
\hline & $2-1-1-B$ & $2-1-2-B$ \\
\hline \multirow{4}{*}{$\begin{array}{l}\text { Consolidation Grade: } \\
\text { Cross Section: } \\
\text { Next to Reinforcement: }\end{array}$} & 4 & 2 \\
\hline & 1/16"- 1/8" air voids & 1/16" crack, 1/16" - 1/8" air voids \\
\hline & 3/4" air void & 1/16" air void \\
\hline & $2-1-1-\mathrm{A}$ & $2-1-2-A$ \\
\hline \multirow{3}{*}{$\begin{array}{l}\text { Consolidation Grade: } \\
\text { Cross Section: } \\
\text { Next to Reinforcement: }\end{array}$} & 2 & 2 \\
\hline & $1 / 16^{\prime \prime}-3 / 8^{\prime \prime}$ holes & 1/16"- 1/8" air voids \\
\hline & No evidence of air voids & 1/16" air void \\
\hline
\end{tabular}

60SF, 2-1-1, NC

60SF, 2-1-2, NC

Average Grout Consolidation Grade: $\underline{\mathbf{2 . 1}}$

Performance of No Vibration/No Admixture Masonry Grout Containing High Replacement of Portland Cement with Fly Ash and Ground Granulated Blast Furnace Slag 


\section{F.2.2.2 Mixture 70SF}

\begin{tabular}{|c|c|c|}
\hline \multirow{5}{*}{$\begin{array}{l}\text { Consolidation Grade: } \\
\text { Cross Section: } \\
\text { Next to Reinforcement: }\end{array}$} & $2-2-1-F$ & $2-2-2-F$ \\
\hline & 2 & 2 \\
\hline & 1/16" - 1/4" air voids & $1 / 16 "-1 / 8$ " air voids \\
\hline & 1/4" air void & 1/4" air void \\
\hline & $2-2-1-E$ & $2-2-2-E$ \\
\hline \multirow{4}{*}{$\begin{array}{l}\text { Consolidation Grade: } \\
\text { Cross Section: } \\
\text { Next to Reinforcement: }\end{array}$} & 2 & 2 \\
\hline & $1 / 16 "$ air voids & $1 / 16 "-1 / 8 "$ air voids \\
\hline & 1/16" air void & 1/8" air void \\
\hline & 2-2-1-D & 2-2-2-D \\
\hline \multirow{4}{*}{$\begin{array}{l}\text { Consolidation Grade: } \\
\text { Cross Section: } \\
\text { Next to Reinforcement: }\end{array}$} & 2 & 2 \\
\hline & 1/16" air voids & 1/16" air voids \\
\hline & 1/8" air void & 1/16" air void \\
\hline & $2-2-1-C$ & $2-2-2-C$ \\
\hline \multirow{4}{*}{$\begin{array}{l}\text { Consolidation Grade: } \\
\text { Cross Section: } \\
\text { Next to Reinforcement: }\end{array}$} & 2 & 2 \\
\hline & 1/16"- $1 / 8 "$ air voids & $1 / 16 "-1 / 8$ " air voids \\
\hline & 1/16" air void & 1/8" air void \\
\hline & 2-2-1-B & $2-2-2-B$ \\
\hline \multirow{4}{*}{$\begin{array}{l}\text { Consolidation Grade: } \\
\text { Cross Section: } \\
\text { Next to Reinforcement: }\end{array}$} & 2 & 1 \\
\hline & 1/16" air voids & 1/16" air voids \\
\hline & 1/16" air void & No evidence of air voids \\
\hline & $2-2-1-A$ & $2-2-2-A$ \\
\hline \multirow{3}{*}{$\begin{array}{l}\text { Consolidation Grade: } \\
\text { Cross Section: } \\
\text { Next to Reinforcement: }\end{array}$} & 2 & 2 \\
\hline & 1/16"- $1 / 8$ " air voids & $1 / 16 "-1 / 8$ " air voids \\
\hline & 1/8" air void & 1/16" air void \\
\hline
\end{tabular}

$$
\text { 70SF, 2-2-1, NC }
$$

70SF, 2-2-2, NC

\section{$\underline{\text { Average Grout Consolidation Grade: }} \underline{\mathbf{1 . 9}}$}




\section{F.2.2.3 Mixture 80SF}

\begin{tabular}{|c|c|c|}
\hline \multirow{5}{*}{$\begin{array}{l}\text { Consolidation Grade: } \\
\text { Cross Section: } \\
\text { Next to Reinforcement: }\end{array}$} & $2-3-1-\mathrm{F}$ & $2-3-2-\mathrm{F}$ \\
\hline & 2 & 2 \\
\hline & $1 / 16 "-1 / 8 "$ air voids & 1/16" air voids \\
\hline & 1/4" air void & 1/16" air void \\
\hline & $2-3-1-5$ & 2-3-2-E \\
\hline \multirow{4}{*}{$\begin{array}{l}\text { Consolidation Grade: } \\
\text { Cross Section: } \\
\text { Next to Reinforcement: }\end{array}$} & 2 & 2 \\
\hline & 1/16"- $1 / 8$ " air voids & 1/16"- $1 / 8 "$ air voids \\
\hline & 1/8" air void & 1/8" air void \\
\hline & 2-3-1-D & 2-3-2-D \\
\hline \multirow{4}{*}{$\begin{array}{l}\text { Consolidation Grade: } \\
\text { Cross Section: } \\
\text { Next to Reinforcement: }\end{array}$} & 2 & 2 \\
\hline & 1/16"- $1 / 8$ " air voids & 1/16" air voids \\
\hline & 1/4" air void & 1/8" air void \\
\hline & $2-3-1-\mathrm{C}$ & $2-3-2-\mathrm{C}$ \\
\hline \multirow{4}{*}{$\begin{array}{l}\text { Consolidation Grade: } \\
\text { Cross Section: } \\
\text { Next to Reinforcement: }\end{array}$} & 4 & 2 \\
\hline & 1/16" air voids & $1 / 16^{\prime \prime}-1 / 8 "$ air voids \\
\hline & 1" air void & 1/8" air void \\
\hline & 2-3-1-B & 2-3-2-B \\
\hline \multirow{4}{*}{$\begin{array}{l}\text { Consolidation Grade: } \\
\text { Cross Section: } \\
\text { Next to Reinforcement: }\end{array}$} & 2 & 2 \\
\hline & $1 / 16 "$ air voids & 1/16"- $3 / 8$ " air voids \\
\hline & 1/8" air void & 1/8" air void \\
\hline & $2-3-1-A$ & $2-3-2-A$ \\
\hline \multirow{3}{*}{$\begin{array}{l}\text { Consolidation Grade: } \\
\text { Cross Section: } \\
\text { Next to Reinforcement: }\end{array}$} & 1 & 4 \\
\hline & 1/16"- $1 / 8$ " air voids & 1/16" air voids \\
\hline & No evidence of air voids & 3/4" air void \\
\hline
\end{tabular}

80SF, 2-3-1, NC

80SF, 2-3-2, NC

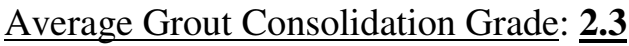




\section{F.2.3 Wall 3}

\section{F.2.3.1 Mixture 100C - C}

\begin{tabular}{|c|c|c|}
\hline \multirow{5}{*}{$\begin{array}{l}\text { Consolidation Grade: } \\
\text { Cross Section: } \\
\text { Next to Reinforcement: }\end{array}$} & $3-1-2-F$ & $3-1-3-F$ \\
\hline & 2 & 2 \\
\hline & $1 / 16 "-1 / 8 "$ air voids & 1/16"- $1 / 8 "$ air voids \\
\hline & $1 / 8$ " air void & 1/16" air void \\
\hline & $3-1-2-E$ & $3-1-3-E$ \\
\hline \multirow{4}{*}{$\begin{array}{l}\text { Consolidation Grade: } \\
\text { Cross Section: } \\
\text { Next to Reinforcement: }\end{array}$} & 2 & 2 \\
\hline & 1/16"- $1 / 8$ " air voids & 1/16" air voids \\
\hline & $1 / 8 "$ air void & 1/8" air void \\
\hline & $3-1-2-\mathrm{D}$ & $3-1-3-\mathrm{D}$ \\
\hline \multirow{4}{*}{$\begin{array}{l}\text { Consolidation Grade: } \\
\text { Cross Section: } \\
\text { Next to Reinforcement: }\end{array}$} & 2 & 2 \\
\hline & 1/16"- 1/8" air voids & 1/16"- $1 / 8 "$ air voids \\
\hline & 1/8" air void & 1/16" air void \\
\hline & $3-1-2-\mathrm{C}$ & $3-1-3-\mathrm{C}$ \\
\hline \multirow{4}{*}{$\begin{array}{l}\text { Consolidation Grade: } \\
\text { Cross Section: } \\
\text { Next to Reinforcement: }\end{array}$} & 1 & 2 \\
\hline & 1/16"- $1 / 8 "$ air voids & 1/16"- $1 / 8 "$ air voids \\
\hline & No evidence of air voids & 1/16" air void \\
\hline & $3-1-2-B$ & $3-1-3-B$ \\
\hline \multirow{4}{*}{$\begin{array}{l}\text { Consolidation Grade: } \\
\text { Cross Section: } \\
\text { Next to Reinforcement: }\end{array}$} & 2 & 2 \\
\hline & $1 / 16 "-1 / 8$ " air voids & $1 / 16 "-1 / 8$ " air voids \\
\hline & 1/16" air void & 1/16" air void \\
\hline & $3-1-2-A$ & $3-1-3-\mathrm{A}$ \\
\hline \multirow{3}{*}{$\begin{array}{l}\text { Consolidation Grade: } \\
\text { Cross Section: } \\
\text { Next to Reinforcement: }\end{array}$} & 2 & 2 \\
\hline & $1 / 16 "-1 / 8$ " air voids & 1/16" air voids \\
\hline & 1/8" air void & 1/16" air void \\
\hline
\end{tabular}

Average Grout Consolidation Grade: $\underline{\mathbf{2 . 0}}$

Performance of No Vibration/No Admixture Masonry Grout Containing High Replacement of Portland Cement with Fly Ash and Ground Granulated Blast Furnace Slag 


\section{F.2.3.2 Mixture 100C - NC}

\begin{tabular}{|c|c|c|}
\hline \multirow{5}{*}{$\begin{array}{l}\text { Consolidation Grade: } \\
\text { Cross Section: } \\
\text { Next to Reinforcement: }\end{array}$} & $3-2-1-F$ & $3-2-2-F$ \\
\hline & 2 & 2 \\
\hline & $1 / 16 "-1 / 8 "$ air voids & 1/16" crack, $1 / 16 "$ - 3/8" air voids \\
\hline & 1/16" air void & 1/16" air void \\
\hline & $3-2-1-E$ & $3-2-2-E$ \\
\hline \multirow{4}{*}{$\begin{array}{l}\text { Consolidation Grade: } \\
\text { Cross Section: } \\
\text { Next to Reinforcement: }\end{array}$} & 2 & 2 \\
\hline & $1 / 16 "-1 / 8 "$ air voids & 1/16" crack, $1 / 16^{\prime \prime}$ air voids \\
\hline & 1/16" air void & 1/16" air void \\
\hline & $3-2-1-\mathrm{D}$ & 3-2-2-D \\
\hline \multirow{4}{*}{$\begin{array}{l}\text { Consolidation Grade: } \\
\text { Cross Section: } \\
\text { Next to Reinforcement: }\end{array}$} & 2 & 2 \\
\hline & $1 / 16 "$ air voids & $1 / 16 "$ crack, $1 / 4 "$ - $1 / 16^{\prime \prime}$ air voids \\
\hline & 1/16" air void & 1/16" air void \\
\hline & $3-2-1-\mathrm{C}$ & $3-2-2-\mathrm{C}$ \\
\hline \multirow{4}{*}{$\begin{array}{l}\text { Consolidation Grade: } \\
\text { Cross Section: } \\
\text { Next to Reinforcement: }\end{array}$} & 2 & 2 \\
\hline & 1/16" air voids & 1/16" air voids \\
\hline & 1/16" air void & 1/16" air void \\
\hline & $3-2-1-B$ & $3-2-2-B$ \\
\hline \multirow{4}{*}{$\begin{array}{l}\text { Consolidation Grade: } \\
\text { Cross Section: } \\
\text { Next to Reinforcement: }\end{array}$} & 1 & 2 \\
\hline & 1/16" air voids & $1 / 16 "-1 / 8 "$ air voids \\
\hline & No evidence of air voids & 1/16" air void \\
\hline & $3-2-1-A$ & $3-2-2-A$ \\
\hline \multirow{3}{*}{$\begin{array}{l}\text { Consolidation Grade: } \\
\text { Cross Section: } \\
\text { Next to Reinforcement: }\end{array}$} & 2 & 2 \\
\hline & $1 / 16 "$ air voids & 1/16" air voids \\
\hline & 1/16" air void & 1/16" air void \\
\hline
\end{tabular}

100C, 3-2-1, NC

100C, 3-2-2, NC

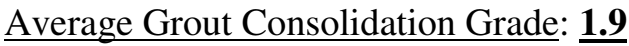

Performance of No Vibration/No Admixture Masonry Grout Containing High Replacement of Portland Cement with Fly Ash and Ground Granulated Blast Furnace Slag 


\section{Appendix G - Rebar Pullout Investigation}

\section{G.1 Bond Strength of Grouts: Wall 4}

ASTM C 900 Test Report:

Standard Test Method for Pullout Strength of Hardened Concrete

Project Identification: Wall Experiment, Rebar Pullout Tests

Testing Lab: $\quad$ CAED High Bay Laboratory

Date Tested: $\quad \frac{1 / 16 / 2013}{}$

\begin{tabular}{|c|c|c|c|c|c|c|}
\hline $\begin{array}{l}\text { Pullout } \\
\text { Sample }\end{array}$ & $\begin{array}{l}\text { Age at } \\
\text { Test } \\
\text { (Days) }\end{array}$ & $\begin{array}{c}\text { Nominal } \\
\text { Reinforcement } \\
\text { diameter, } d_{b} \\
\text { (in.) }\end{array}$ & $\begin{array}{l}\text { Embedment } \\
\text { Length, } l \\
\text { (in.) }\end{array}$ & $\begin{array}{c}\text { Ultimate } \\
\text { Axial Force, } \\
T(\mathrm{lb} .)\end{array}$ & $\begin{array}{l}\text { Bond } \\
\text { Strength, } \tau \\
\quad \text { (psi) }\end{array}$ & $\begin{array}{l}\text { Avg. Bond } \\
\text { Strength, } \tau \\
\quad \text { (psi) }\end{array}$ \\
\hline $4-1-1-1$ & 168 & $3 / 8$ & $1511 / 16$ & 10175 & 551 & \multirow{3}{*}{548} \\
\hline $4-1-1-2$ & 168 & $3 / 8$ & $153 / 4$ & 10125 & 546 & \\
\hline $4-1-1-3$ & 168 & $3 / 8$ & $1511 / 16$ & 10150 & 549 & \\
\hline $4-2-1-1$ & 168 & $3 / 8$ & $153 / 4$ & 7900 & 426 & \multirow{3}{*}{425} \\
\hline $4-2-1-2$ & 168 & $3 / 8$ & $153 / 4$ & 7850 & 423 & \\
\hline $4-2-1-3$ & 168 & $3 / 8$ & $153 / 4$ & 7900 & 426 & \\
\hline 4-3-1-1 & 170 & $3 / 8$ & $153 / 4$ & 10850 & 585 & \multirow{3}{*}{571} \\
\hline $4-3-1-2$ & 170 & $3 / 8$ & $153 / 4$ & 10650 & 574 & \\
\hline 4-3-1-3 & 170 & $3 / 8$ & $155 / 8$ & 10225 & 555 & \\
\hline 4-4-1-1 & 170 & $3 / 8$ & $153 / 4$ & 7625 & 411 & \multirow{3}{*}{401} \\
\hline $4-4-1-2$ & 170 & $3 / 8$ & $1513 / 16$ & 7575 & 407 & \\
\hline 4-4-1-3 & 170 & $3 / 8$ & $1511 / 16$ & 7125 & 386 & \\
\hline 4-5-1-1 & 170 & $3 / 8$ & $153 / 4$ & 7750 & 418 & \multirow{3}{*}{409} \\
\hline $4-5-1-2$ & 170 & $3 / 8$ & $1511 / 16$ & 7525 & 407 & \\
\hline $4-5-1-3$ & 170 & $3 / 8$ & $151 / 2$ & 7350 & 403 & \\
\hline 4-6-1-1 & 170 & $3 / 8$ & $151 / 2$ & 10900 & 597 & \multirow{3}{*}{589} \\
\hline 4-6-1-2 & 170 & $3 / 8$ & $1511 / 16$ & 10850 & 587 & \\
\hline $4-6-1-3$ & 170 & $3 / 8$ & $1511 / 16$ & 10800 & 584 & \\
\hline $4-7-1-1$ & 170 & $3 / 8$ & $153 / 4$ & 9700 & 523 & \multirow{3}{*}{524} \\
\hline $4-7-1-2$ & 170 & $3 / 8$ & $1513 / 16$ & 9600 & 515 & \\
\hline $4-7-1-3$ & 170 & $3 / 8$ & $151 / 2$ & 9750 & 534 & \\
\hline 4-8-1-1 & 170 & $3 / 8$ & $153 / 4$ & 10125 & 546 & \multirow{3}{*}{548} \\
\hline $4-8-1-2$ & 170 & $3 / 8$ & $153 / 4$ & 10150 & 547 & \\
\hline $4-8-1-3$ & 170 & $3 / 8$ & $159 / 16$ & 10100 & 551 & \\
\hline
\end{tabular}

Performance of No Vibration/No Admixture Masonry Grout Containing High Replacement of Portland Cement with Fly Ash and Ground Granulated Blast Furnace Slag 


\section{G.2 Normalized Data for Bond Strengths}

Average Bond Strength Per Mixture was Normalized to the Square Root of the Average Corrected Net Strengths x 12.043, from the Wall Experiment at Curing Time 130 Days: Appendix D

\begin{tabular}{|c|c|c|c|c|}
\hline Grout & $\begin{array}{c}\text { Avg. } \\
\text { Bixture } \\
\text { Bond } \\
\tau \text { (psi) }\end{array}$ & $\begin{array}{c}\text { Average Net } \\
\text { Corrected } \\
\text { Compressive } \\
\text { Strength of } \\
\text { Wall } \\
\text { Experiment, } \\
f_{g}(\mathrm{psi})\end{array}$ & $\begin{array}{c}12.043^{*} \\
\mathrm{SQRT}\left(f_{g}\right) \\
(\mathrm{psi})\end{array}$ & $\begin{array}{c}\text { Normalized } \\
\text { Values* }\end{array}$ \\
\hline 100C-C & 548 & 2925 & 651.3 & 0.84 \\
\hline $100 \mathrm{C}-\mathrm{NC}$ & 425 & 2744 & 630.9 & 0.67 \\
\hline $50 \mathrm{~F}$ & 571 & 1513 & 468.4 & 1.22 \\
\hline $60 \mathrm{~F}$ & 401 & 1135 & 405.7 & 0.99 \\
\hline $70 \mathrm{~F}$ & 409 & 833 & 347.6 & 1.18 \\
\hline $60 \mathrm{SF}$ & 589 & 2250 & 571.2 & 1.03 \\
\hline $70 \mathrm{SF}$ & 524 & 1963 & 533.6 & 0.98 \\
\hline $80 \mathrm{SF}$ & 548 & 1702 & 496.8 & 1.10 \\
\hline
\end{tabular}

*Normalized Values $=\frac{\tau}{12.043 \sqrt{f_{g}}} \quad[\mathrm{psi} / \mathrm{psi}]$

Performance of No Vibration/No Admixture Masonry Grout Containing High Replacement of Portland Cement with Fly Ash and Ground Granulated Blast Furnace Slag 


\section{G.3 Required Development Length of Reinforcement}

Modified rebar development length equation (Eq.4) : $\quad l_{d}=\frac{0.13 d_{b}^{2}\left(\frac{T}{A_{s}}\right) \gamma}{K \sqrt{f_{g}}}$

Average compressive strength of grouts from The Compression Experiment, $f_{\mathrm{g}}$ (Appendix B) :

$\begin{array}{ll}100 \mathrm{C} & : f_{\mathrm{g}} \text { taken after } 28 \text { days of curing } \\ 50 \mathrm{~F}, 60 \mathrm{~F}, 70 \mathrm{~F}, 60 \mathrm{SF}, 70 \mathrm{SF}, 80 \mathrm{SF} & : f_{\mathrm{g}} \text { taken after } 56 \text { days of curing }\end{array}$

Nominal diameter of reinforcement, $d_{\mathrm{b}}=\underline{0.375}$ in.

Effective cross-sectional area of reinforcement, $A_{\mathrm{s}}=\quad 0.11$ in. ${ }^{2}$

$K$, shall not exceed the smallest of :

min. masonry clear cover: $\quad$ Shown in table below

$5 d_{\mathrm{b}} \quad=1.875$ in.

Reinforcement size factor, $\gamma=$

\begin{tabular}{|c|c|c|c|c|c|}
\hline $\begin{array}{c}\text { Grout } \\
\text { Mixture }\end{array}$ & Sample & $\begin{array}{l}\text { Min. } \\
\text { Masonry } \\
\text { Clear } \\
\text { Cover } \\
\text { (in.) } \\
\end{array}$ & $\begin{array}{l}\text { Average } \\
\text { Comp. } \\
\text { Strength, } \\
f_{\mathrm{g}}(\mathrm{psi})\end{array}$ & $\begin{array}{c}\text { Tensile } \\
\text { Axial Force, } \\
T(\mathrm{lb})\end{array}$ & $\begin{array}{l}\text { Req. Development } \\
\text { Length of } \\
\text { Reinforcement Bars, } \\
l_{\mathrm{d}} \text { (in.) }\end{array}$ \\
\hline $100 \mathrm{C}-\mathrm{C}$ & 4-1-1-1 & 2.94 & 2531 & 10175 & 17.85 \\
\hline $100 \mathrm{C}-\mathrm{C}$ & 4-1-1-2 & 3.31 & 2531 & 10125 & 17.77 \\
\hline $100 \mathrm{C}-\mathrm{C}$ & 4-1-1-3 & 3.25 & 2531 & 10150 & 17.81 \\
\hline $100 \mathrm{C}-\mathrm{NC}$ & $4-2-1-1$ & 3.31 & 2531 & 7900 & 13.86 \\
\hline $100 \mathrm{C}-\mathrm{NC}$ & $4-2-1-2$ & 3.13 & 2531 & 7850 & 13.77 \\
\hline $100 \mathrm{C}-\mathrm{NC}$ & $4-2-1-3$ & 3.00 & 2531 & 7900 & 13.86 \\
\hline $50 \mathrm{~F}$ & 4-3-1-1 & 3.19 & 1552 & 10850 & 24.31 \\
\hline $50 \mathrm{~F}$ & 4-3-1-2 & 3.13 & 1552 & 10650 & 23.86 \\
\hline $50 \mathrm{~F}$ & $4-3-1-3$ & 3.06 & 1552 & 10225 & 22.91 \\
\hline $60 \mathrm{~F}$ & 4-4-1-1 & 2.75 & 884 & 7625 & 22.64 \\
\hline $60 \mathrm{~F}$ & 4-4-1-2 & 2.63 & 884 & 7575 & 22.50 \\
\hline $60 \mathrm{~F}$ & $4-4-1-3$ & 2.56 & 884 & 7125 & 21.16 \\
\hline $70 \mathrm{~F}$ & 4-5-1-1 & 3.25 & 495 & 7750 & 30.75 \\
\hline $70 \mathrm{~F}$ & $4-5-1-2$ & 2.81 & 495 & 7525 & 29.86 \\
\hline $70 \mathrm{~F}$ & $4-5-1-3$ & 3.06 & 495 & 7350 & 29.16 \\
\hline $60 \mathrm{SF}$ & 4-6-1-1 & 3.25 & 2136 & 10900 & 20.82 \\
\hline $60 \mathrm{SF}$ & 4-6-1-2 & 2.56 & 2136 & 10850 & 20.72 \\
\hline $60 \mathrm{SF}$ & 4-6-1-3 & 3.19 & 2136 & 10800 & 20.63 \\
\hline 70SF & 4-7-1-1 & 2.06 & 2188 & 9700 & 18.31 \\
\hline $70 \mathrm{SF}$ & $4-7-1-2$ & 1.88 & 2188 & 9600 & 18.12 \\
\hline $70 \mathrm{SF}$ & $4-7-1-3$ & 2.63 & 2188 & 9750 & 18.40 \\
\hline 80SF & $4-8-1-1$ & 3.06 & 2064 & 10125 & 19.67 \\
\hline $80 \mathrm{SF}$ & $4-8-1-2$ & 2.88 & 2064 & 10150 & 19.72 \\
\hline 80SF & $4-8-1-3$ & 3.31 & 2064 & 10100 & 19.62 \\
\hline
\end{tabular}

Performance of No Vibration/No Admixture Masonry Grout Containing High Replacement of Portland Cement with Fly Ash and Ground Granulated Blast Furnace Slag 


\section{G.4 Normalized Data for Development Length of Reinforcement}

The required theoretical development lengths of reinforcements, $l_{\mathrm{d}}$, were normalized to the actual embedment lengths, $l$, of the rebar pullout specimens

\begin{tabular}{|c|c|c|c|c|c|}
\hline $\begin{array}{l}\text { Grout } \\
\text { Mixture }\end{array}$ & Sample & $\begin{array}{l}\text { Embedment } \\
\text { Length, } \\
l \text { (in.) }\end{array}$ & $\begin{array}{c}\text { Req. } \\
\text { Development } \\
\text { Length of } \\
\text { Reinforcement } \\
\text { Bars, } l_{\mathrm{d}} \text { (in.) }\end{array}$ & $\begin{array}{c}\text { Normalized } \\
\text { Values* }\end{array}$ & $\begin{array}{c}\text { Average } \\
\text { Normalized } \\
\text { Values per } \\
\text { Mixture }\end{array}$ \\
\hline $100 \mathrm{C}-\mathrm{C}$ & $4-1-1-1$ & 15.69 & 17.85 & 1.14 & \multirow{3}{*}{1.13} \\
\hline $100 \mathrm{C}-\mathrm{C}$ & $4-1-1-2$ & 15.75 & 17.77 & 1.13 & \\
\hline $100 \mathrm{C}-\mathrm{C}$ & $4-1-1-3$ & 15.69 & 17.81 & 1.14 & \\
\hline $100 \mathrm{C}-\mathrm{NC}$ & $4-2-1-1$ & 15.75 & 13.86 & 0.88 & \multirow{3}{*}{0.88} \\
\hline $100 \mathrm{C}-\mathrm{NC}$ & $4-2-1-2$ & 15.75 & 13.77 & 0.87 & \\
\hline $100 \mathrm{C}-\mathrm{NC}$ & $4-2-1-3$ & 15.75 & 13.86 & 0.88 & \\
\hline $50 \mathrm{~F}$ & $4-3-1-1$ & 15.75 & 24.31 & 1.54 & \multirow{3}{*}{1.51} \\
\hline $50 \mathrm{~F}$ & $4-3-1-2$ & 15.75 & 23.86 & 1.52 & \\
\hline $50 \mathrm{~F}$ & $4-3-1-3$ & 15.63 & 22.91 & 1.47 & \\
\hline $60 \mathrm{~F}$ & 4-4-1-1 & 15.75 & 22.64 & 1.44 & \multirow{3}{*}{1.40} \\
\hline $60 \mathrm{~F}$ & $4-4-1-2$ & 15.81 & 22.50 & 1.42 & \\
\hline $60 \mathrm{~F}$ & $4-4-1-3$ & 15.69 & 21.16 & 1.35 & \\
\hline $70 \mathrm{~F}$ & $4-5-1-1$ & 15.75 & 30.75 & 1.95 & \multirow{3}{*}{1.91} \\
\hline $70 \mathrm{~F}$ & $4-5-1-2$ & 15.69 & 29.86 & 1.90 & \\
\hline $70 \mathrm{~F}$ & $4-5-1-3$ & 15.50 & 29.16 & 1.88 & \\
\hline 60SF & 4-6-1-1 & 15.50 & 20.82 & 1.34 & \multirow{3}{*}{1.33} \\
\hline $60 \mathrm{SF}$ & $4-6-1-2$ & 15.69 & 20.72 & 1.32 & \\
\hline 60SF & 4-6-1-3 & 15.69 & 20.63 & 1.31 & \\
\hline $70 \mathrm{SF}$ & 4-7-1-1 & 15.75 & 18.31 & 1.16 & \multirow{3}{*}{1.17} \\
\hline 70SF & $4-7-1-2$ & 15.81 & 18.12 & 1.15 & \\
\hline 70SF & $4-7-1-3$ & 15.50 & 18.40 & 1.19 & \\
\hline $80 \mathrm{SF}$ & 4-8-1-1 & 15.75 & 19.67 & 1.25 & \multirow{3}{*}{1.25} \\
\hline $80 \mathrm{SF}$ & $4-8-1-2$ & 15.75 & 19.72 & 1.25 & \\
\hline $80 \mathrm{SF}$ & $4-8-1-3$ & 15.56 & 19.62 & 1.26 & \\
\hline
\end{tabular}

*Normalized Values $=\frac{l_{d}}{l} \quad[$ in. $/$ in. $]$

Performance of No Vibration/No Admixture Masonry Grout Containing High Replacement of Portland Cement with Fly Ash and Ground Granulated Blast Furnace Slag 
Appendix H - Metric Conversions

\begin{tabular}{|c|c|c|c|}
\hline Quantity & $\begin{array}{l}\text { U.S. Customary } \\
\text { Units }\end{array}$ & Metric Units & Multiply* \\
\hline \multirow{3}{*}{ Length } & $\mathrm{ft.}$. & $\mathrm{m}$ & 0.3048 \\
\hline & $\mathrm{ft}$. & $\mathrm{mm}$ & 304.8 \\
\hline & in. & $\mathrm{mm}$ & 25.4 \\
\hline \multirow{3}{*}{ Area } & $\mathrm{yd}^{2}$ & $\mathrm{~m}^{2}$ & 0.83612736 \\
\hline & $\mathrm{ft}^{2}{ }^{2}$ & $\mathrm{~m}^{2}$ & 0.09290304 \\
\hline & in. $^{2}$ & $\mathrm{~mm}^{2}$ & 645.16 \\
\hline \multirow{3}{*}{ Volume } & $\mathrm{yd}^{3}$ & $\mathrm{~m}^{3}$ & 0.764555 \\
\hline & $\mathrm{ft}^{3}$ & $\mathrm{~m}^{3}$ & 0.0283168 \\
\hline & in. $^{3}$ & $\mathrm{~mm}^{3}$ & $16,387.06$ \\
\hline Mass density & pcf & $\mathrm{kg} / \mathrm{m}^{3}$ & 16.0185 \\
\hline \multirow[b]{2}{*}{ Force } & lb-force & $\mathrm{N}$ & 4.44822 \\
\hline & $\begin{array}{c}\text { kip } \\
(1,000 \mathrm{lb} \text {-force) }\end{array}$ & $\mathrm{kN}$ & 4.44822 \\
\hline \multirow{2}{*}{ Force/unit length } & $1 \mathrm{~b} / \mathrm{ft}$ & $\mathrm{N} / \mathrm{m}$ & 14.5939 \\
\hline & $\mathrm{kip} / \mathrm{ft}$ & $\mathrm{kN} / \mathrm{m}$ & 14.5939 \\
\hline \multirow{3}{*}{ Force/unit area } & psf & $\mathrm{Pa}\left(\mathrm{N} / \mathrm{m}^{2}\right)$ & 47.8803 \\
\hline & psi & $\mathrm{MPa}$ & 0.00689476 \\
\hline & ksi & $\mathrm{MPa}$ & 6.89476 \\
\hline
\end{tabular}

*Multiply U.S. customary units by given number to convert into metric units 